\title{
The aetio-pathogenesis of gastric cancer : clinical and experimental studies
}

Citation for published version (APA):

Houben, G. M. P. (1997). The aetio-pathogenesis of gastric cancer : clinical and experimental studies.

[Doctoral Thesis, Maastricht University]. Universiteit Maastricht. https://doi.org/10.26481/dis.19970618gh

Document status and date:

Published: 01/01/1997

DOI:

10.26481/dis.19970618gh

Document Version:

Publisher's PDF, also known as Version of record

\section{Please check the document version of this publication:}

- A submitted manuscript is the version of the article upon submission and before peer-review. There can be important differences between the submitted version and the official published version of record.

People interested in the research are advised to contact the author for the final version of the publication, or visit the DOI to the publisher's website.

- The final author version and the galley proof are versions of the publication after peer review.

- The final published version features the final layout of the paper including the volume, issue and page numbers.

Link to publication

\footnotetext{
General rights rights.

- You may freely distribute the URL identifying the publication in the public portal. please follow below link for the End User Agreement:

www.umlib.nl/taverne-license

Take down policy

If you believe that this document breaches copyright please contact us at:

repository@maastrichtuniversity.nl

providing details and we will investigate your claim.
}

Copyright and moral rights for the publications made accessible in the public portal are retained by the authors and/or other copyright owners and it is a condition of accessing publications that users recognise and abide by the legal requirements associated with these

- Users may download and print one copy of any publication from the public portal for the purpose of private study or research.

- You may not further distribute the material or use it for any profit-making activity or commercial gain

If the publication is distributed under the terms of Article $25 \mathrm{fa}$ of the Dutch Copyright Act, indicated by the "Taverne" license above, 
The aetio-pathogenesis of gastric cancer

clinical and experimental studies 
- Houben, Gerardus Maria Petrus ISBN 90-9010635-9

Part of the studies described in this thesis were made possible by financial support of Astra Pharmaceutica BV.

The financial support of Astra Pharmaceutica BV and Janssen-Cilag BV for the publication of this thesis is gratefully acknowledged. 


\title{
The aetio-pathogenesis of gastric cancer
}

\author{
clinical and experimental studies
}

\section{PROEFSCHRIFT}

ter verkrijging van de graad van doctor aan de Universiteit Maastricht,

op gezag van de Rector Magnificus, Prof. Mr. M.J. Cohen, wolgens het besluit van het College van Decanen, in het openbaar te verdedigen op woensdag 18 juni 1997 om 16.00 uur

door

\section{G M P Houben}

geboren op 22-08-1957 te Maastricht 


\section{Promotor}

Prof dr RW Stockbrügger

\section{Co-promotores}

Dr W Hameeteman

Dr AP de Bruine

\section{Beoordelingscommissie}

Prof dr PB Soeters, (voorzitter)

Prof dr PJC van Breda Vriesman

Prof dr JCS Kleinjans

Prof dr CBHW Lamers (Rijkssuniversiteit Leiden)

Prof dr JW Rode (St. Vincent Hospital, Melbourne) 
Aan mijn moeder

Ter herinnering aan mijn vader 


\section{Contents}

Chapter I: Introduction and aim of the study 9

Chapter II: The frequency of Helicobacter pylori associated peptic ulcer disease and of autoimmune-associated conditions in gastric and renal cancer: a retrospective comparison in 267 patients $\mathbf{3 3}$

Chapter III: Twenty-four-hour intragastric acidity: $300 \mathrm{mg}$ ranitidine b.d., 20 mg omeprazole o.m., $40 \mathrm{mg}$ omeprazole o.m. vs. placebo 45

Chapter IV: Intragastric bacterial growth, nitrates, nitrites and $\mathrm{N}$-nitroso compounds after $300 \mathrm{mg}$ ranitidine b.d., $20 \mathrm{mg}$ omeprazole, $40 \mathrm{mg}$ omeprazole and placebo $\mathbf{5 9}$

Chapter V: Twenty-four-hour intragastric $\mathrm{pH}$, basal and meal-stimulated serum pepsinogens $A$ and $C$ following $300 \mathrm{mg}$ ranitidine b.d., $20 \mathrm{mg}$ omeprazole o.m., $40 \mathrm{mg}$ omeprazole o.m. or placebo 79

Chapter VI: Twenty-four-hour intragastric $\mathrm{pH}$, basal and meal-stimulated serum gastrin, and plasma chromogranin A after short-term acid inhibition 95

Chapter VII: Helicobacter pylori and non-Helicobacter pylori intragastric bacterial flora in patients with intestinal and diffuse type of gastric adenocarcinoma 109

Chapter VIII: General discussion

Chapter IX: Summary 137

Chapter X: 'Samenvatting 143

Dankwoord 149

Curriculum vitae $\mathbf{1 5 3}$ 


\section{Chapter I}

\section{Introduction and aims of the study}

GMP Houben, RW Stockbrügger 


\section{Introduction}

Worldwide well over half a million people die from gastric cancer each year, and in terms of cancer mortality, gastric cancer is second in importance to lung cancer ${ }^{1.2}$. In the period $1981-86$, there was a more than six-fold difference in international mortality rate from gastric cancer, from $32.2 / 100,000$ males in Japan, to $5.7 / 100,000$ in the USA. Even larger national differences are known ${ }^{3}$.

More remarkable, however, has been the recent consistent decline in incidence in gastric cancer mortality, seen in nearly all countries ${ }^{4-9}$, and this is primarily due to a decrease of the most common form of gastric cancer, the intestinal type ${ }^{10}$. On the other hand, the incidence of the less frequently occurring diffuse type carcinoma and also carcinomas located in the cardia region increases gradually ${ }^{11-17}$.

In the search for the causes of gastric cancer, therefore, we can conclude that causative agents are likely to be wide-spread, variable in prevalence between populations, and declining in importance, or that protective agents are widespread, variable, and increasing in prevalence ${ }^{\mathrm{i}}$.

The stomach occupies a critical position in the digestive tract, as ingested products remain there for a significant amount of time in a relatively crude form. It is therefor easy to imagine that environmental factors, especially ingested carcinogens, co-carcinogens, and protective factors play an important role in gastric carcinogenesis.

Diet has been one of the most extensively evaluated environmental factors. Although no single dietary factor has been identified, being common in all highrisk areas, the dietary characteristics of the majority of populations at high risk are: high intake of complex carbohydrates, high intake of salt and nitrates present in preserved - fermented and salted - vegetables, fish and meat, low intake of animal fat and protein, low intake of vitamins $\mathrm{A}, \mathrm{C}$ and $\mathrm{E}^{19-33}$. Concerning these data, it is of interest that these factors appear to have the greatest impact in early life. Several studies on Japanese migrants to the United States have shown that migrants maintained their high risk whereas their offspring never experienced the high risk of their ancestors ${ }^{34-35}$. High intake of alcohol was associated with a six-fold higher relative risk of gastric cancer in comparison to non-drinkers ${ }^{36}$. Smokers and exsmokers have an increased risk of gastric cancer ${ }^{36,37}$. At this moment is seems reasonable to advice to stop smoking and using excessive alcohol, and to use a varied diet limited in calories and supplemented with fibre, fresh fruits and vegetables. 


\section{Atrophic gastritis as a cancer-prone lesion}

Atrophic gastritis is known as one of the precursor lesions in gastric cancer ${ }^{38-44}$. Before the introduction of the Sydney Classification atrophic gastritis was traditionally divided into three types, type $A$, type $B$, and type $A B^{45,46}$.

Type A atrophic gastritis is located in the body and the fundus of the stomach and is associated with achlorhydria or severe hypochlorhydria. This condition can lead to bacterial overgrowth in the stomach with aerobic and facultatively anaerobic flora, enabling the conversion of nitrate to nitrite and further to $\mathrm{N}$-nitroso compounds. N-nitroso compounds constitute one of the most potent carcinogens known to induce gastric cancer, especially the intestinal type of gastric carcinoma ${ }^{47-59}$. Type A chronic gastritis is frequently associated with the presence of parietal cell antibodies in the serum, and can lead to pernicious anaemia ${ }^{45}$. Helicobacter pylori (H.pylori) colonization is uncommon in type A gastritis ${ }^{60}$.

Type B atrophic gastritis is located primarily in the antrum of the stomach, with the possibility of expanding into the corpus, and is associated with normo- or hypersecretion of gastric acid and with peptic ulceration. Thus far, this type of gastritis had been considered idiopathic although irritants, both exogenous, such as hot drinks, spices, alcohol, and tobacco, and endogenous, such as bille reflux, were suggested causes. Nowadays, H.pylori is thought to be the major cause of type B gastritis $^{61-63}$.

Type $A B$ atrophic gastritis consists of patchy gastritis in both antral and body mucosa, and is associated with an increased incidence of gastric ulceration, dysplasia and gastric cancer. According to $\mathrm{Correa}^{64}$, a high prevalence of this multifocal gastritis is observed in populations consuming a diet excessive in salty foods and deficient in fresh fruits and fresh leafy vegetables. Patients with this condition have a gradual decrease in hydrochloric acid secretion, and an increase in gastric $\mathrm{pH}$. As a consequence, also this condition can lead to bacterial overgrowth. Autoantibodies to parietal cells are not present.

In the western world achlorhydric atrophic gastritis is found not only in pernicious anaemia but is also latent in about 3 to $6 \%$ of the general population ${ }^{65}$. In a middleaged Dutch population between 40 and 64 years $(n=564)$, an achlorhydric atrophic gastritis without pernicious anaemia was found in $2.5 \%$.

In a study from the Mayo Clinic of 622 consecutive patients with gastric cancer, $31 \%$ were combined with achlorhydria and $69 \%$ with remaining acid secretion ${ }^{67}$. 
Of the achlorhydric patients, $29 \%$ had manifest pernicious anaemia, and $71 \%$ achlorhydria without pernicious anaemia. Tumour(s) were located in the upper half of the stomach in $71 \%$ of patients with achlorhydria and in $63 \%$ of patients with pernicious anaemia, while only $12 \%$ of patients with acid had tumours located proximally in the stomach.

Twenty-two percent of patients with achlorhydria and $24 \%$ of patients with pernicious anaemia had two or more independent tumours, while only $2.4 \%$ of the lesions in patients with gastric acid exhibited such multicentricity. Polypoid tumours were present in $75 \%$ and $66 \%$ in patients with pernicious anaemia and achlorhydria, respectively, and in $4 \%$ in patients with acid secretion. Benign polyps accompanying the malignant tumour were observed in $16 \%$ and $10 \%$ of patients with achlorhydria and patients with pernicious anaemia, respectively, and in $1 \%$ of those with preserved acid secretion.

Fifty percent of patients with achlorhydria and $56 \%$ of patients with pernicious anaemia had blood group type A, while only $36 \%$ of patients with acid had type A. Type $O$ occurred in $25 \%$ and $33 \%$ of patients with achlorhydria with and without pernicious anaemia, respectively, and in $48 \%$ of patients with acid secretion.

The conclusion from the authors was that gastric analysis should direct suspicion to a particular area of the stomach, and that the mucosal background upon which a gastric cancer develops influences the clinical, pathologic and prognostic characteristics of the tumour.

Gastric cancer associated with atrophic gastritis and achlorhydria has many characteristics which make it look like a different entity compared to cancer arising. in stomachs with preserved secretory capacity. It is not clear wether these two types of cancer have different epidemiologic and aetiologic features. There is no universally accepted explanation for why patients with atrophic gastritis develop carcinoma in the upper segment of the stomach.

In type A chronic atrophic gastritis, a preserved antral mucosa but a profound degree of atrophy in the fundus and body is seen, to such an extent that the normal rugae are lost. There is a total or subtotal atrophy of the specialized glands, with widespread intestinal metaplasia of the surface epithelium. There is loss of normal mucus-secreting cells and replacement by goblet cells and absorptive cells. In the most florid cases, Paneth cells can be present at the base of the pits ${ }^{68-70}$. Because of the achlorhydria present in type A gastritis there is a compensatory increase in antral gastrin secreting-cells (G cells), with as a result hypergastrinaemia ${ }^{71}$.

Type B atrophic gastritis starts in the distal antrum and spreads proximally along the lesser curvature. The degree of atrophy is not as profound as in type A 
gastritis, and because the disease is mainly antral in distribution achlorhydria is uncommon, and usually there is a normogastrinaemia. Advanced cases of type B gastritis are almost invariably accompanied by intestinal metaplasia; however, in contrast to type A gastritis, the metaplasia is more likely to be patchy.

In type $\mathrm{AB}$ atrophic gastritis the process starts at the junction of the antrum and the body of the stomach as independent foci, which then become confluent and spread along the lesser curvature and then to other areas of the mucosa.

The normal stomach has a pH between 1 and 2 , and the normal gastric lumen is either sterile or contains organisms that are barely able to survive. Most of the normal ingested gastric flora cannot metabolize at $\mathrm{pH}$ values below 4 , and is consequently killed by such acidic conditions ${ }^{72,73}$. In type $A$ and type $A B$ atrophic gastritis, the decreased acid secretion reaches a point where the gastric luminal $\mathrm{pH}$ does not fall below 4 .

The achlorhydric stomach has been known for decades to be populated by a complex bacterial flora rich in both upper respiratory tract and faecal type organisms $^{74}$. A wide range of the bacterial species of the gastric flora can reduce nitrate to nitrite by nitrate reductase, an enzyme that requires anaerobic conditions for both its production and its activity ${ }^{54-56,59.75}$. Some bacterial species are able to produce an enzyme capable of catalysing $\mathrm{N}$-nitrosation, with as a result the formation of $\mathrm{N}$-nitroso compounds $\mathrm{s}^{76-78}$.

There is ample evidence that exogenous and endogenous $\mathrm{N}$-nitroso compounds may contribute to gastric carcinogenesis ${ }^{51,52}$. The nitrite concentration in the gastric juice is very much higher in patients with achlorhydria than in control persons with a normal acidic stomach. In patients with pernicious anaemia, after gastric surgery, and in controls, the severity of epithelial dysplasia correlated well with both the concentration of the gastric bacterial flora and the concentration of nitrite in the gastric juice ${ }^{79-83}$.

In patients with achlorhydria after gastric surgery, and in patients with pernicious anaemia, there is an increased risk not only for cancer of the stomach but also for cancer of the large bowel, bronchi, pancreas, biliary tract, oesophagus, bladder, and breas ${ }^{82-86}$. Possibly $\mathrm{N}$-nitroso compounds act as carcinogens locally as well as distally ${ }^{87.90}$.

Unfortunately, the very important question of the relation between gastric epithelial dysplasia and neoplasia, and the concentration of $\mathrm{N}$-nitroso compounds, has not been finally resolved because of the analytical problems with these compounds ${ }^{91}$. However, bacterially generated $\mathrm{N}$-nitroso compounds are probably not the sole 
carcinogenic mechanism in type A gastritis: other possible causes may be connected with elevated serum gastrin levels, altered cell turn over, and immunologic and hereditary traits ${ }^{92-1000}$.

\section{Helicobacter pylori}

Until recently the normal stomach has been thought to be too acidic to permanently harbour bacteria. However, spiral organisms have been observed in the human stomach as far as back as $1874^{101-103}$. These microorganisms excited little interest until 1982, when they were first isolated by Warren and Marshall and named Campylobacter pylori ${ }^{104}$. In 1989 the organism was renamed Helicobacter pylori ${ }^{105}$. Epidemiological, biochemical, morphological, retrospective/prospective follow-up studies have recently been performed studying the role of H.pylori as a causal factor in the aetiology of gastric cancer.

Epidemiological studies indicate a moderately increased risk for gastric cancer in H.pylori-positive subjects compared with Helicobacter-negative controls. In a study by Parsonnet ${ }^{106}, H$.pylori was a risk factor for the development of adenocarcinoma of the stomach with an odds ratio of 3.6 for the total group of carcinomas, and odds ratios of 3.1 and 8.0, respectively, for the intestinal type and the diffuse type, compared to Helicobacter-negative controls, tested for IgG antibodies to H.pylori by an ELISA. H.pylori was a significant risk factor for adenocarcinoma in women (odds ratio 18.0) but not in men (odds ratio 2.0). In blacks, H.pylori infection appeared to be a more important risk factor for adenocarcinoma than in whites (odds ratios, respectively, 9.0 and 2.9), but the wide confidence intervals overlapped. In comparison, a history of gastric surgery was a risk factor for cancer at an odds ratio of 16.9 , independent of H.pylori.

Nomura ${ }^{107}$ found an increased risk for gastric carcinoma among Japanese Americans in Hawaii with a positive H.pylori-specific IgG antibody with an odds ratio of 6.0 compared to H.pylori negative controls. Forman ${ }^{108}$ found an odds ratio of 2.77 in a British population. A pooled analysis of all three studies produced a significantly elevated odds ratio of $3.8(95 \% \mathrm{Cl}: 2.3-6.2)^{109}$. An even higher odds ratio of 13.3, was found for gastric cancer patients under the age of 40 years ${ }^{100}$. Talley ${ }^{111}$ found a significant association between H.pylori infection and non-cardia gastric cancer, with an odds ratio of 2.67 . Within the subset of patients with noncardia gastric cancer a statistically non-significant tendency existed for those with the intestinal versus those with the diffuse type of gastric cancer to have an 
H.pylori infection (odds ratios, 4.57 and 2.25 , respectively). Probably the relative risks are even higher, because the blood samples to determine the H.pylori status, in a number of the cancer patients, were taken only shortly before the diagnosis was made ${ }^{112}$. In the retrospective studies a number of patients in this group was also considered to be H.pylori negative, although they could have been infected in the past, since severe mucosal atrophy can lead to disappearance of H.pylori and it can be reasoned that, on the long term, this will lead to a decrease or even a normalization of the antibody titres ${ }^{113}$.

However, some studies fail to find differences in H.pylori prevalence between gastric cancer cases and matched controls ${ }^{114-118}$. This is sometimes due to the choice of the control group. In a study from Kuipers et al. ${ }^{114}$, of 116 patients with gastric cancer, the H.pylori seropositivity was $77 \%$; it was $79 \%$ in controls who were endoscopy patients without ulcer or gastric preneoplastic lesions. In a study from Varia et al. ${ }^{115}$ an H.pylori seropositivity of $80 \%$ was found in patients with gastric cancer. In controls with non-ulcer dyspepsia the H.pylori seropositivity was $69 \%$. No difference was found in $H$.pylori seropositivity between intestinal $(79 \%)$ and diffuse ( $85 \%$ ) type gastric cancer.

The hypotheses how H.pylori contributes to the aetiopathogenesis of gastric cancer are multiple. In morphological studies by Craanen et al ${ }^{119}, H$.pylori seems to be linked to mucosal atrophy and intestinal metaplasia. To study the relationship between intestinal metaplasia and H.pylori, antral biopsies were taken from 533 patients. Overall intestinal metaplasia was found in $25 \%$ of patients, and $H$.pylori in $54 \%$. The prevalence of intestinal metaplasia and H.pylori was found to be strongly age-related, both being more prevalent in patients older than 50 years than in patients younger than 50 years. Intestinal metaplasia was found more often in H.pylori-positive patients than in H.pylori-negative patients (34\% versus $15 \%$ ). This suggests that H.pylori-related gastritis may evolve into intestinal metaplasia. Since the time of colonization with H.pylori appears to be a crucial factor, the occurrence of H.pylori-related gastritis at a young age might render such individuals at greater risk for developing intestinal metaplasia and gastric cancer of the intestinal type than those infected with H.pylori at older age or not at all. Whether H.pylori has to be present at all times during this process or whether it is only necessary as an initial trigger needs further research ${ }^{120}$. There are some other studies in which H.pylori seemed to be mainly associated with the intestinal type of gastric cancer ${ }^{121-123}$.

Other morphological studies do not support the hypothesis: H.pylori infection 
leading to intestinal metaplasia leading to gastric cancer of the intestinal type (24-127. $^{\text {. }}$ Loffeld et al. ${ }^{124}$ and Wee et al. ${ }^{125}$ found H.pylori as frequently in diffuse as in intestinal type gastric carcinoma. Furthermore, Loffeld found no difference in the presence of $H . p y l o r i$ in gastric cancer patients (in 59\% positive) and non-ulcer dyspepsia patients ( $55 \%$ positive).

Sobala ${ }^{128}$ found, in chronic antral gastritis, an association between H.pylori and inflammation, but not between H.pylori and atrophy and intestinal metaplasia.

H.pylori associated gastritis can be the base for both intestinal and diffuse gastric cancer, but consequently different pathways will arise from chronic gastritis ${ }^{126,129}$. In the intestinal type the histological sequence of $H$.pylori associated gastritis towards atrophic gastritis and intestinal metaplasia will play a role. The diffuse type may arise more directly from hyperplastic or atypical necks of gastric glands through primary involvement of genes affecting cell to cell and cell to matrix junctional proteins ${ }^{129.130}$. Probably cytotoxic effects of H.pylori, like ammonia, acetaldehyde and neutrophilic products such as reactive oxygen metabolites, also play a $\operatorname{part}^{131-133}$.

One of the biochemical pathways by which H.pylori influences gastric carcinogenesis may be via ascorbic acid. This correlation has been studied by Sobala et al. ${ }^{31}$, and Correa et al. ${ }^{134}$. Ascorbic acid, the reduced form of vitamin C, acts as an anti-oxidant, converting nitrite to nitrous oxide and is therefore potentially important in the prevention of gastric cancer ${ }^{135-137}$. Ascorbic acid is better suited for this than other anti-oxidants as the optimum $\mathrm{pH}$ for this reaction is around 4. A high intake of food rich in vitamin $\mathrm{C}$ is associated with a reduced incidence of gastric cancer in both case-control and wider population-based studies $^{32,138-140}$.

Sobala et al. ${ }^{31}$ found that gastric levels of total vitamin $\mathrm{C}$ and ascorbic acid were substantially lower in patients with type B chronic gastritis compared with patients with a normal gastric mucosa. In those patients with chronic gastritis, total vitamin $\mathrm{C}$ and ascorbic acid levels in gastric juice did not differ significantly in accordance with the presence of atrophy, intestinal metaplasia, or involvement of the body of the stomach. However, there was a strongly significant trend to lower vitamin C intake in association with severe gastritis. Subjects with hypochlorhydria had significantly lower total vitamin $\mathrm{C}$ concentrations in gastric juice and extremely low ascorbic acid concentrations compared with subjects with a low $\mathrm{pH}$.

The concentration of ascorbic acid in gastric juice is therefore a potentially critical factor in the prevention of intragastric $\mathrm{N}$-nitrosation. One could speculate on whether the lower gastric vitamin $\mathrm{C}$ levels in the presence of gastritis may be accounted for by reduced secretion, disruption of active uptake, increased back 
diffusion through unhealthy mucosa, increased utilization by the inflamed tissue, or even by utilization by $H$.pylori.

Lowered intragastric vitamin C/ascorbic acid levels were seen in chronic gastritis, but they also occur in other conditions: at elevated intragastric $\mathrm{pH}_{\text {, }}$ after bacterial overgrowth in the stomach; after H.pylori infection (with increasing levels after H.pylori eradication). Low intragastric vitamin C/ascorbic acid levels are probably the consequence of any intragastric bacterial growth.

The strongest evidence for a connection between H.pylori and gastric cancer would be provided by prospective follow-up studies. In a recent such study by Kuipers et al., 105 patients were studied ${ }^{63}$. They had been endoscoped because of upper abdominal complaints $11: 5$ years (mean) previously, with biopsies taken. The study population was then divided into two groups, H.pylori-negative at the first visit (histology/serology), consisting of 49 patients, and H.pylori-positive at the first visit, the remaining 56 patients.

At the follow-up endoscopy, again biopsies were taken. Of the H.pylori-negative group, 45 patients developed no histological changes, two patients a mild chronic gastritis, one a moderate body gastritis, and one patient a severe atrophic body gastritis, leading to a pernicious anaemia.

In the H.pylori positive group, in $\mathbf{5}$ patients a regression of atrophic changes was seen, 15 patients showed an increase of atrophy and intestinal metaplasia by at least two Sydney degrees, in one patient a development of an early gastric carcinoma was seen. A progression of atrophy and intestinal metaplasia associated with H.pylori was seen.

Three other cohort follow-up studies on the development of atrophic gastritis have been published ${ }^{141-143}$. The well known Finnish study was the first and had the longest follow up extending up to 30 years ${ }^{141}$. This study started with blindly sampled biopsy specimens. For historical reasons the H.pylori status of the included individuals was not reported. The annual development of atrophic gastritis in the body of the stomach was approximately $1 \%$.

The second and largest study with inclusion of 1422 subjects from a high gastric cancer risk area in Colombia reported an annual increase of $1.7 \%$ in prevalence of atrophy of the body of the stomach, $0.9 \%$ in prevalence of intestinal metaplasia, and $0.7 \%$ in prevalence of dysplasia during a mean follow-up of 5.1 years $^{142}$.

The third study came from Estonia and reported on 142 individuals with a followup of 6 years $^{143}$. This was the only study in which the H.pylori status of the included subjects was reported. The authors were however unable to study the strength of any association between atrophy and H.pylori as virtually all included subjects were infected. The annual increase in prevalence of atrophic body gastritis 
in this population was $1.25 \%$. The study by Kuipers ${ }^{63}$ is thus the first study to provide strong direct evidence that H.pylori may be an important factor in the aetiology of gastric cancer.

The prevalence of $\mathrm{H}$. pylori infection in patients with pernicious anaemia is low; in several reports ranging from $3.5 \%$ to $21 \%^{144-146}$. It contrasts strongly with a prevalence of $71 \%$ in the age-, race-, and sex-matched controls. This suggests that the pathological process in pernicious anaemia prevents the gastric mucosa from colonization by H.pylori. In type B gastritis, H.pylori is present in about $95 \%$ of subjects, and serum IgG or IgA antibodies to H.pylori will be present.

If transition from type B gastritis to type A gastritis could take place, achlorhydria will develop and H.pylori will disappear from the stomach. However it would be unlikely that antibodies against $H$.pylori would also disappear, and that there would be a change in histology from atrophy of the antrum mucosa (as occurs in type B gastritis) to a normal antrum mucosa (as in type A gastritis).

It is also unlikely that H.pylori may act as a triggering mechanism for the autoimmune response in type $A$ gastritis. In a recent study ${ }^{147}$ it was found that autoantibodies against gastric $\mathrm{H}, \mathrm{K}$-ATPase, a major auto-antigen in type A gastritis, and antibodies against $H$.pylori recognize different epitopes. This renders a joint pathogenesis less probable. Neither can H.pylori explain the elevated titres of nongastric auto-antibodies and other autoimmune phenomena in type A gastritis ${ }^{148}$.

There seem to be at least two possibilities of bacterial association with gastric cancer, one in achlorhydric atrophic body gastritis and one in normo-secretory atrophic antral gastritis; their frequency ratio seems to be about 1:3. In the first group various bacteria, in the latter H.pylori and, in addition, various other bacteria may play a role in gastric carcinogenesis.

\section{Gastrin and enterochromaffine-like cells}

Long-lasting reduction of gastric acid secretion has been shown to induce antral gastrin-producing $(\mathrm{G})$ cell hyperplasia accompanied by hypergastrinaemia ${ }^{149-152}$. As gastrin constitutes a powerful trophic factor for the argyrophilic enterochromaffinlike (ECL) cells of the oxyntic mucosa, ECL-cell hyperplasia, and even dysplasia and carcinoid tumour formation, may be a consequence of hypergastrinaemia ${ }^{153-158}$ In man, gastric carcinoid tumours derived from hyperplastic ECL-cells have been seen in patients with pernicious anaemia ${ }^{159,160}$, or with the Zollinger-Ellison syndrome, particularly when it is part of the multiple endocrine neoplasia type I 
(MEN D) syndrome ${ }^{161}$. In both instances there is considerable hypergastrinaemia. In the study by Borch et al. ${ }^{160}$, in 123 patients with pernicious anaemia, gastric carcinoid tumours were found by endoscopy in $5(4 \%)$ who had a diagnosis of pernicious anaemia for a mean duration of 19 years. Thus, massive hypergastrinaemia for many years appears to be necessary for tumours to develop in humans. In the sporadic Zollinger-Ellison syndrome, ECL cell proliferation is usually limited to hyperplastic lesions of the simple or linear type ${ }^{162-164}$. In contrast, in patients with the MEN-1 syndrome and chronic atrophic gastritis type A (pernicious anaemia), ECL cell lesions are frequently dysplastic or overtly carcinoid in nature ${ }^{16 !}$. Factors other than hypergastrinaemia seem therefore be involved in ECL cell transformation. In the MEN-1 syndrome, the loss of a suppressor oncogene in $11 \mathrm{q} 13$ may be related ${ }^{165}$. In atrophic gastritis, either the achlorhydria or the alterations in biology of the associated mucosa may be involved in the ECL cell transformation ${ }^{166}$.

In experimental conditions, rats treated for a long period with histamine-2-receptor (H2) blockers ${ }^{150,167,168}$, or proton-pump inhibitors ${ }^{150,169}$, or those subjected to partial fundectomy ${ }^{170}$ developed ECL-cell hyperplasia leading to carcinoid tumour formation in up to $30 \%$ of the female population ${ }^{150}$. From a considerable number of clinical studies it is apparent that in man the hypergastrinaemia related to profound gastric inhibition stabilizes with time and has mostly a moderate range $\mathrm{e}^{155,171-173}$.

Waldum et al. ${ }^{174,175}$ found evidence of ECL cell-derived tumour cells in $40 \%$ of the diffuse gastric carcinomas. They concluded that a proportion of the diffuse gastric carcinomas originate from ECL cells. Moreover, they suggested that - given the slow-growing rate of such malignancies - even modest gastrin elevations over many years may exert a biologically relevant effect ${ }^{176}$.

None of the information available at present allows us to precisely define the magnitude of the risk related to long-term hypergastrinaemia induced by drugs in humans ${ }^{177,178}$.

Of particular interest is possibly the combination of hypergastrinaemia with H.pylori gastritis ${ }^{179}$. In a large multicenter, cohort-study, Kuipers et al. ${ }^{180}$ showed that long-term acid suppressive therapy with omeprazole is associated with a persistent increase in inflammation of the corpus and with the development of atrophic gastritis and argyrophil-cell hyperplasia in H.pylori positive patients, but not in those who are H.pylori negative.

Summarizing, it seems most likely that there are multiple aetio-pathogenetic factors in gastric carcinogenesis, the relative importance of which may differ in the course of time and according to the geographic area.

Detection and surveillance of achlorhydric atrophic gastritis on the one hand, and 
reduction of the infection rate of $H$.pylori on the other, may prove suitable means in the prevention of gastric cancer mortality.

In this context, reliable diagnostic methods are mandatory concerning potential risk factors such as atrophic gastritis, intragastric bacterial flora, $\mathrm{N}$-nitroso compounds and their precursors, as well as hypergastrinaenia. 


\section{Aims of the study}

The aims of the study were:

- to investigate the frequency of autoimmune-associated conditions in a retrospective series of gastric cancer patients and to compare this to the frequency of a history of peptic ulcer disease, which is strongly associated with intragastric H.pylori infection.

- to compare gastric acid inhibition by three different drug treatments that are used in the short- and long-term treatment of acid related disorders.

- to evaluate the effects of the three regimens of acid inhibition in a double-blind, placebo controlled, multiple cross-over study to elucidate the mechanisms leading to the formation of $\mathrm{N}$-nitroso compounds.

- to elucidate the effects of acid inhibition on serum gastrin and serum pepsinogen levels.

- to elucidate the effects of acid inhibition on serum gastrin and plasma chromogranin A levels, the latter known as a marker for the presence and growth of enterochromaffin-like cell tumours.

- to study in a large series of patients with gastric cancer at the time of diagnosis, to what proportion H.pylori and non-H.pylori intragastric bacterial flora were present at this ultimate stage of gastric carcinogenesis. 


\section{References}

1 Parkin D, Laara E, Muir C. Estimate of the worldwide frequency of sixteen major cancers in 1980. Int J Cancer 1988:41:184-97.

2 Muir C, Waterhouse $J$, Mack $T$ et al. Cancer incidence in five continents, Vol 5. IARC Scientific Publications, 1987. No. 88. IARC, Lyon.

3 Munoz N. Descriptive epidemiology of gastric cancer. In Gastric Carcinigenesis (eds Reed P, Hill M); Excerpta Medica, Amsterdam 1988;51-69.

4 Howson $C_{\text {, Hiyama }} \mathrm{T}$, Wynder $\mathrm{E}$. The decline in gastric cancer: epidemiology of an unplanned triumph. Epidemiol Rev 1986;8:1-27.

5 Devesa S, Silverman D. Cancer incidence and mortality trends in the United States: 1935-74. J Natl Cancer Inst 1978;60:545-71.

6 Pollack $E$, Horm $J$. Trends in cancer incidence and mortality in the United States", 1969-76. J Natl Cancer Inst 1980;64:1091-1103.

7 Viste A, Soreide O, Glattre E. Stomach cancer: major trends in incidence during introduction of gastroscopy service in Norway. Scand J Gastroenterol 1985;20:99-108.

8 Breaux J, Bringaze W, Chappuis C, Cohn I. Adenocarcinoma of the stomach: A review of 35 years and 1,710 cases. World J Surg 1990;14:580-6.

9 Nobrega $\mathbb{F}$, Sedlack $J$, Sedlack R et al. A decline in carcinoma of the stomach. A diagnostic artefact? Mayo Clin Proc 1983;58:255-60.

10 Lauren $P$. The two histological main types of gastric carcinoma: diffuse and som called intestinal-type carcinoma. Acta Path Microbiol Scand 1965;64:31-49.

11 Yang P, Davis S. Epidemiological characteristics of the adenocarcinoma of gastric cardia and distal stomach in the United States, 1973-1982. Int J Epidemiol 1988; 17:293-7.

12 Powell $\mathrm{J}, \mathrm{McC}$ Conkey $\mathrm{C}$. Increasing incidence of adenocarcinoma of the gastric cardia and adjacent sites. Br J Cancer 1990;62:440-3.

13 Blot W, Devesa S, Kneller R. Fraumeni J. Rising incidence of adenocarcinoma of esophagus and gastric cardia. JAMA 1991;265:1287-9.

14 Correa P, Chen V. Gastric cancer. Cancer Surv 1994;19-20:55-76.

15 Munoz N, Asvall $\mathrm{J}$. Time trends of intestinal and diffuse types of gastric cancer in Norway. Int I Cancer 1971;8:144-57.

16 Munoz $N$, Connelly $\mathbb{R}$. Time trends of intestinal and diffuse types of gastric cancer in the United States. Int J Cancer 1971;8:158-64.

17 Amorosi $A$, Bianchi $S$, Buiatti $E$ et al. Gastric cancer in a high risk area in Italy.Histopathologic patterns according to Lauren's classification. Cancer 1988;62:2191-6.

18 Forman D. The etiology of gastric cancer. In: Relevance to Human Cancer of N-Nitroso Compounds, Tobacco Smoke and Mycotoxins (eds O'Neill I, Chen J, Bartsch H.); International Agency for Research on Cancer, Lyon, 1991;22-32. 
19 Buiati $E$, Palli D, Decarli A et al. A case-control study of gastric cancer and diet in Italy. Int J Cancer 1989;44:611-6.

20 Hansson $L$, Nyren $O$, Bergstrom $R$ et al. Diet and risk of gastric cancer. A population-based case-control study in Sweden. Int I Cancer 1993;55:181-9.

21 Ramon J, Serra L, Cerdo C. Oromi J. Dietary factors and gastric cancer risk. A case-control study in Spain. Cancer 1993;71:1731-5.

22 Kinlen $\mathrm{L}$, Willows $\mathrm{A}$, Goldblatt $\mathrm{P}$, Yudkin J. Tea consumption and cancer. $\mathrm{Br} J$ Cancer 1988;58:397-401.

23 Risch $H$, Jain $M$, Choi $N$, et al. Dietary factors and the incidence of cancer of the stomach. Am J Epidemiol 1985;122:947-59.

24 Levin $B$. The rolle of dietary factors and chemoprevention in gastrointestinal malignancy. Curr Opin Oncol 1995;7:377-80.

25 Correa $P$, Cuello $C$, Fajardo $L$ et al. Diet and gastric cancer: nutrition survey in a high risk area. J Nall Cancer Inst 1983;70:673-8.

26 Joossens J, Geboers J. Nutrition and gastric cancer. Nutr Cancer 1981; 2: 250-61.

27 Stehr $P$, Gloninger $M_{*}$ Kuller $L$ et al. Dietary vitamin $A$ deficiencies and stomach cancer. Am J Epidemiol 1985;121:65-70.

28 Carr B. Chemical carcinogens and inhibitors of carcinogenesis in human diet. Cancer 1985;55:218-24.

29 Weilsberger $J$, Wynder $E$, Horn $C$ et al. Nutritional factors and etiologic mechanisms in the causation of gastrointestinal cancers. Cancer 1982; 50: 2541-9.

30 Newell G. Nutrition and diet. Cancer 1983;51:2420-5.

31 Sobala $G$, Schorah $C$, Sanderson $M$ et al. Ascorbic acid in the human stomach. Gastroenterology 1989;97:357-63.

32 Cuello $C$, Correa $P$, Haenszel W et al. Gastric cancer in Columbia. I. Cancer risk and suspected environmental agents. J Natl Cancer Inst 1976;57:1015-20.

33 Tannenbaum S, Moran D, Rand W et al. Gastric cancer in Columbia. IV. Nitrite and other ions in gastric contents of residents from a high-risk region. J Natl Cancer Inst $1979 ; 62 ; 9-12$.

34. Haenszel $W$. Cancer mortality and incidence among the foreign born in the United States. J Natl Cancer Inst $1961 ; 26 ; 37-132$.

35 Haenszel W, Kurihara M. Studies of Japanese migrants. I. Mortality from cancer and other diseases among Japanese in the United States. I Natl Cancer Inst $1968 ; 40: 43-68$.

36 Hoey J, Montvernay C, Lambert R. Wine and tobacco: risk factors for gastric cancer in France. Am J Epidemiol 1981;113:668-74.

37 Wu-Williams A, Yu M, Mack T. Life-style, workplace, and stomach cancer by subsite in young man of Los Angles County. Cancer Res 1990;50:2569-76.

38 Siurala M, Varis K, Wiljasalo M. Studies of patients with atrophic gastritis: a 10-15 year follow-up. Scand J Gastroenterol 1966;1:40-8. 
39 Sipponen $\mathrm{P}$, Kekki M, Haapakoski J et al. Gastric cancer risk in chronic atrophic gastritis: statistical calculations of cross sectional data. Int I Cancer 1985;35:173-7.

40 Siuralia M, Thamaki $T$, Lehtola $M$. Atrophic gastritis and its sequelae. Scand J Gastroenterol 1974;9:441-6.

41 Testoni $P$, Masci $E$, Marchi $R$ et al. Gastric cancer in chronic atrophic gastritis. Associated gastric ulcer adds no further risk. J Clin Gastroenterol 1987:9:298 302.

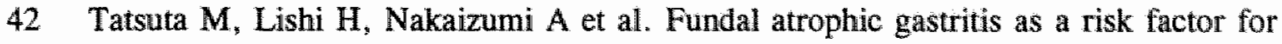
gastric cancer. Int J Cancer 1993;53:70-74.

43 Cheli $R$, Santi L, Ciancamerla G, Cancianni G. A clinicall and statistical follow-up of atrophic gastritis. Am J Digest Dis 1973;18:1061-6.

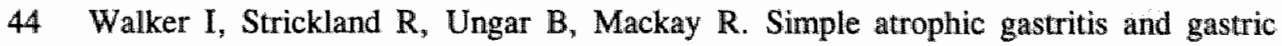
carcinoma. Gut 1971;12:906-9.

45 Strickland $R$, Mackay I. A reappraisal of the nature and significance of chronic atrophic gastritis. Dig Dis 1973;18:426-40.

46. Glass G, Pitschumoni C. Atrophic gastritis. Hum Pathol 1975;6:219-50.

47 Tannenbaum $\mathrm{S}$. $\mathrm{N}$-nitroso compounds: a perspective on human exposure. Lancet 1983;i:629-31.

48 Reed $\mathrm{P}$, Smith $\mathrm{P}$, Haines $\mathrm{K}$ et al. Effect of cimetidine on gastric juice N-nitrosamine concentration. Lancet 1981;ii:553-6.

49 Lijnski W. Nitrosamines and nitrosamides in the aetiology of gastrointestinal cancer. Cancer 1977;2446-9.

50 Reed P, Smith $\mathrm{P}$, Haines $\mathrm{K}$ et al. Gastric juice $\mathrm{N}$-nitrosamines in health and gastroduodenal disease. Lancet 1981;ii:550-2.

51 Ruddell W, Bone $\mathrm{E}$, Hill $\mathrm{M}$, Walters $\mathrm{C}$. Pathogenesis of gastric cancer in pernicious anaemia. Lancet 1978; ii:521-3.

52 Ruddell W, Bone $\mathrm{E}$, Hill $\mathrm{M}$ et al. Gastric juice nitrate. A risk factor for cancer in the hypochlorhydric stomach? Lancet 1976;ii:1037-9.

53 Elder J, Ganuli P, Gillespie I. Cimetidine and gastric cancer. Lancet 1979; i: 1005-6.

54 Ruddell $W$, Axon A, Findlay $J$ et al. Effect of cimetidine on the gastric bacterial flora. Lancet 1980;i:672-4.

55 Stockbrügger $\mathbf{R}$, Cotton $\mathrm{P}$, Eugenides $\mathrm{N}$ et al. Intragastric nitrites, nitrosamines and bacterial owergrowth during cimetidine treatment. Gut 1982;23:1048-54.

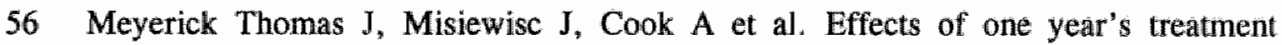
with ranitidine and of truncal vagotomy on gastric contents. Gut 1987;28:726-38.

57 Stockbrügger $\mathrm{R}$, Cronstedt $\mathbf{J}$, Dotevall $\mathrm{G}$ et al. The intragastric milieu during gastric ulcer treatment with pirenzepine $50 \mathrm{mg}$ b.i.d. or cimetidine $400 \mathrm{mg}$ b.i.d. Scand J Gastroenterol 1988;26:685-8.

58 Sharma B, Santana I, Wood E et al. Intragastric bacterial activity and nitrosation before, during and after treatment with omeprazole. Br Med J 1984;289;717-9.

59 Verdu E, Viani F, Armstrong D et al. Effect of omeprazole on intragastric bacterial count, nitrate, nitrites and N-nitroso compounds. Gut 1994;35:445-460. 
60 O'Connor $H$, Axon A, Dixon M. Campyllobacter-like organisms unusual in type $A$ (pernicious anaemia) gastritis. Lancet $1984 ;$ ii: 1091 .

61. Wyatt J, Dixon M. Chronic gastritis: a pathogenetic approach. J Pathol $1988 ; 154: 113-24$.

62 International Agency for Research on Cancer. IARC Mono-graphs on the ewaluation of carcinogenic risks to humans, Vol 61. Schistosomes, liver flukes and Helicobacter pylori. Lyon: 1994.

63 Kuipers $\mathrm{E}$, Uyterlinde $\mathrm{A}$, Nelis $\mathrm{G}$ et al. Long term follow up of Helicabacter associated gastritis. Lancet $1995 ; 345: 1525-28$.

64 Correa P. Chronic gastritis: a clinico-pathological classification. Am J Gastroenterol 1988:83:504-9.

65 Christiansen $\mathrm{P}$. The incidence of achlorhydria and hypo-chlorhydria in healthy subjects and patients with gastrointestinal diseases. Scan J Gastroenterol $1968 ; 3: 497-508$.

66 Bins $M$, Burgers $\mathrm{P}$, Selbach $\mathrm{S}$ et al. The relation between basal gastric $\mathrm{pH}$ and serum gastrin. Digestion 1982;23:271-3.

67 Kuster G, Remine W, Dockerty M. Gastric cancer in pernicious anaemia and in patients with and without achlorhydria. Ann Surg 1972;175:783-9.

68 Whitehead R, Truelove S, Gear M. The histological diagnosis of chronic gastritis in fiber-optic gastroscope biopsy specimens, J Clin Pathol 1972;25:1-11.

69 Owen D. Gastritis and duodenitis. In: Appelman H, editor. Pathology of the esophagus and duodenum. Contemporary Issues in Surgical Pathology, $1984 ; 4: 37-77$.

70 Barwick K. Chronic gastritis. The pathologist's role. In: Rosen P, Fechner R, editors. Pathology annual, 1987;22:223-51.

71 McGuigan J, Trudeau W. Serum gastrin concentrations in pernicious anaemia. N Engl J Med 1970;282:358-60.

72 Gianella $R$, Broitman $S$, Zamchek $N$. Gastric acid barrier to ingested microorganisms in man: studies in vivo and in vitro. Gut 1972;13:251-6.

73 Howden C, Hunt R. Relationship between gastric secretion and infection (progress report). Gut 1987;28:96-107.

74 Hill M. Gastric carcinogenesis: luminal factors. In: Reed P, Hill M, editors. Gastric carcinogenesis, Amsterdam: Elsevier, 1988:187-99.

75 Stockbrigger $\mathbb{R}$. Bacterial overgrowth as a consequence of reduced gastric acidity. Scan J Gastroenterol 1985; Supll 111:7-16.

76 Calmels $\mathrm{S}$, Oshima $H_{4}$ Vincent $\mathrm{P}$ et al ${ }^{\prime}$ Screening of microorganisms for nitrosation catalysis at $\mathrm{pH} 7$ and kinetic studies on nitrosamine formation from secondary amines by $\mathbf{E}$. Coli strains. Carcinogenesis 1985;6:911-915.

77 Leach S, Thompson M, Hill M. Bacterially catalysed N-nitrosation in the human stomach. Carcinogenesis 1987;8:1907-12.

78 Sander J. Nitrosaminsynthese durch Bakterien. Hoppe Seyler's Z Physiol Chem $1968 ; 349: 429-32$. 
79 Jones S, Davies P, Savage A. Gastric-juice nitrite and gastric cancer. Lancet 1987 ; i: 1355 .

80 Hall $C$, Cook A, Darkin D et al. Evaluation of the nitrosamine hypothesis of gastric carcinogenesis in man. Clin Sci 1984;66:34P-5P.

81 Mortensen N, Thomas W, Jones S, Savage A. Endoscopic screening for premalignant changes 25 years after gastrectomy: results of a five-year prospective study. Br J Surg 1984;71:363-7.

82 Blackburn E, Callender S, Dacie J. Possible association between pernicious anmemia and leukaemia: a prospective study of 1,625 patients with a note on the very high incidence of stomach cancer. Int $\mathrm{J}$ Cancer $1968 ; 3: 163-70$.

83 Borch $\mathrm{K}$. Kullman $\mathrm{E}$, Hallhagen $\mathrm{S}$ et al. Increased incidence of pancreatic neoplasia. in pernicious anaemia. World J Surg 1988;12:866-70.

84 Brinton $L$, Gridley $G$, Hrubec $\mathrm{Z}$ et al. Cancer risk following pernicious anaemia. $\mathrm{Br}$ J Cancer 1989;59:810-3.

85 Talley $\mathrm{N}$, Chute $\mathrm{C}$, Larson $\mathrm{D}$. Risk of colorectal adenocarcinoma in pernicious anaemia. A population based cohort study. Ann Int Med 1989;111;738-42.

86 Caygill C, Knowles R, Hill M. Relationship between pernicious anaemia and gastric cancer. Deutsche Zeit Onkol 1990;22:120-2.

87 Magee $P$. The experimental basis for the role of nitroso compounds in human cancer. Cancer Surv 1989;8:207-39.

88 Magee P. Nitrosamines and human cancer: introduction and overview. Eur II Cancer Prev 1996;5 Suppl 1:7-10.

89 Caygill C, Hill M, Hall C et al. Increased risk of cancer at multiple sites after gastric surgery for peptic ullcer. Gut 1987;28:924-8.

90 Caygill $C$, Hill $M$. Malignancy following surgery for benign peptic disease: a review. Ital J Gastroenterol 1992;24:218-24.

91 Reed P. Studies of stable N-nitroso compounds in human gastric juice - a review. Eur J Cancer Prev 1996;5 Suppl 1:75-82.

92 den Hartog $G$, Jansen $J$, Schaardenburg $D$ et al. Plasma gastrin responses to bombesin and antral gastrin concentrations in patients with the intestinal type of gastric cancer. Cancer Res 1988;48:2296-8.

93 Correa P. Human gastric carcinogenesis: a multistep and multifactorial process. First American Cancer Society Award Lecture on Cancer Epidemiology and Prevention. Cancer Res 1992;52:6735-40.

94 Stockbrügger $\mathbf{R}$, Menon $\mathrm{C}$, Beilby $\mathbf{J}$ et al. Gastroscopic screening in 80 patients with pernicious anaemia. Gut $1983 ; 24: 1141-7$.

95 Zanghieri G, Di Gregorio C, Sachetti C et al. Familial occurrence of gastric cancer in the 2-year experience of a population base registry. Cancer 1990;66:2047-51.

96 La Vecchia C, Negri E, Franceschi $S$, Gentile A. Family history and the risk of stomach and colorectal cancer. Cancer 1992;70:50-5.

97 Correa P, Shiao Y. Phenotypic and genotypic events in gastric carcinogenesis. Cancer Res 1994;54:1941S-3. 
98 Mckie A, Filipe $M$, Lemoine $N$. Abnormalities affecting the APC and MCC tumour suppressor gene loci on chromosome $5 q$ occur frequently in gastric cancer but not in pancreatic cancer. Int J Cancer 1993;55:598-603.

99 Uchino $S$, Tsuda $H$, Noguchi $M$ et al. Frequent loss of heterozygosity at the DCC locus in gastric cancer. Cancer Res 1992;52:3099-102.

100 Seruca R, David L, Holm R et al. p53 mutations in gastric carcinogenesis. Br J Cancer 1992;65:798-10.

101 Bottcher. Dorpater Medischinische Zeitschrift 1874;5:48.

102 Kreinitz W. Ueber das Auftreten von Spirochaeten verschiedener Form in Mageninhalt bei Carcinoma venticuli. Dtsch Med Wochenschr 1906;32:872.

103 Goodwin C. Helicobacter pylori: 10th anniversary of its culture in april 1982. Gut 1993;34:293-4.

104 Warren J, Marshall B. Unidentified curved bacillus on gastric epithelium in active chronic gastritis. Lancet 1983;i:1273-5.

105 Goodwin C, Armstrong J, Chilvers $\mathrm{T}$ et al. Transfer of Campylobacter pyloridis and Campylobacter mustulae to Helicobacter gen. nov, as Helicobacter pylori comb. nov. and Helicobacter mustulae comb. nov, respectively. Int J Syst Bacteriol 1989;39:2378-9.

106 Parsonnet J, Friedman G, Vandersteen D et al, Helicobacter pylori infection and the risk of gastric carcinoma. N Engl J Med 1991;325:1127-31.

107 Nomura A, Stemmerman G, Chyou P et al. Helicobacter pylori infection and gastric carcinoma among Japanese Americans in Hawaii. $N$ Engl $J$ Med 1991;325:1132-6.

108 Forman D, Newell D, Fullerton $F$ et al. Association between infection with H.pylori and risk of gastric cancer: evidence from a prospective investigation. $\mathrm{Br}$ Med J 1991;302;1302-5.

109 Forman D, Webb P, Parsonnet J. Helicobacter pylori and gastric cancer. Lancet 1994;343:243-4.

110 Kikuchi S, Wada O, Nakajima $\mathrm{T}$ et al. Serum anti-Helicobacter pylori antibody and gastric carcinoma among young adults. Cancer 1995;75:2789-93.

111 Talley N, Zinsmeister A, Weaver A et al. Gastric adenocarcinoma and Helicobacter pylori infection. J Natl Cancer Inst 1991;83:1734-9.

112 Forman D. The prevalence of Helicobacter pylori in gastric cancer. Aliment Pharmacol Ther 1995;9 (Suppl 2):71-76.

113 Karnes W, Samloff I, Siurala $M$ et al. Positive serum antibody and negative tissue staining for Helicobacter pylori in subjects with atrophic body gastritis. Gastroenterology 1991;101:167-74.

114 Kuipers E, Gracia-Casanova M, Pena A et al. Helicobacter pylori serology in patients with gastric carcinoma. Scand J Gastroenterol 1993;28:433-7.

115 Varia D, Miglio M, Menegatti $M$ et al. Relationship between gastric carcinoma and Helicobacter pylori. Acta Gastroenterol Belg 1993;56 Suppl:62. 
116 Sierra R, Munoz N, Pena A et al. Antibodies to Helleobacter pylori and pepsinogen levels in children from Costa Rica: comparison of two areas with different risks for stomach cancer. Cancer Epidemiol Biomarkers Prev 1992;1:449-54.

117 Palli $\mathbb{D}$, Decarli $A$, Cipriani $\mathbb{F}$ et al. Helicobacter pylori antibodies in areas of Italy at varying gastric cancer risk. Cancer Epidemiol Biomarkers Prev 1993;2:37-40.

118 Fukao A, Komatsu S, Tsubono $\mathrm{Y}$ et al. Helicobacter pylori infection and chronic atrophic gastritis among Japanese blood donors: a cross-sectional study. Cancer Causes Control 1993;4:307-12.

119 Craanen $M$, Dekker W, Blok P et al. Intestinal metaplasia and Helicobacter pylori. An endoscopic bioptic study of the gastric antrum. Gut 1992;33:16-20.

120 Blaser M, Chyou P, Nomura A. Age at establishment of Helicobacter infection and gastric carcinoma, gastric ulcer, and duodenal ulcer risk. Cancer Res $1995 ; 55: 562-5$.

121 Guarner J, Mohar A, Parsonnet J, Halperin D. The association of H.pylori with gastric cancer lesions in Chiapas, Mexico. Cancer 1993;71:297-301.

122 Buruk F, Berberog $\| u$ U, Pak. I et al. Gastric cancer and Helicobacter pylori infection. Br J Surg 1993;80:378-9.

123 Nogeira A, Ribeiro $G$, Rodriguez $M$ et al. Prevalence of Helicobacter pylori in Brazilian patients with gastric cancer. Am J Clin Pathol 1993;100:236-9.

124 Loffeld R, Willems I, Flendrig J, Arends J. Helicobacter pylori and gastric carcinoma. Histopathology 1990;17:537-41.

125 Wee A, Kang J, Teh M. Helicobacter pylori and gastric cancer: correlation with gastritis, intestinal metaplasia and tumour histology. Gut 1992;33:1029-32.

126 Sipponen $\mathrm{P}$, Kosunen $\mathrm{T}$, Valle $\mathrm{J}$ et al. Helicobacter pylori infection and chronic gastritis in gastric cancer. J Clin Pathol 1992;45:319-23.

127 Hansson L, Engstrand L, Nyren O, Lindgren A. Prevalence of Helicobacter pylori infection in subtypes of gastric cancer. Gastroenterol $1995 ; 109: 885-8$.

128 Sobala G, Axon A, Dixon M. Morphology of chronic antral gastritis: relationship to age, Helicobacter pylori status and peptic ulceration. Eur J Gastroenterol Hepatol $1992 ; 4: 825-9$.

129 Solcia $\mathrm{E}$, Fiocca $\mathbf{R}$, Luinetti $\mathrm{O}$ et al. Intestinal and diffuse gastric cancers arise in at different background of Helicobacter pylori gastritis through different gene involvement. Am J Pathol 1996;20 (Suppl 1):S8-S22.

130 Fenoglio-Preiser C, Noffsinger A, Belli I, Stemmermann N. Pathologic and phenotypic features of gastric cancer. Sem Oncol 1996;23:292-306.

131 Rautelin $\mathrm{H}$, Blomberg B, Fredlund $\mathrm{H}$ et al. Incidence of Helicabacter pylori strains activating neutrophils in patients with peptic ulcer disease. Gut 1993;34:599-603.

132 Davies G, Simmonds $\mathrm{N}$, Stevens $\mathrm{T}$ et al. Helicabacter pylori stimulates antral mucosal reactive oxygen metabolite production in vivo. Gut 1994;35:179-85.

133 Gotz J, van Kan C, Verspaget H et al. Gastric mucosal superoxide dismutases in Helicobacter pylori infection. Gut 1996;38:502-6. 
134 Correa P, Fontham S, Ruiz B et al. Gastric juice ascorbic acid after intravenous imjection: effect of ethnicity, $\mathrm{pH}$, and Helicobacter pylori infection. I Nall Cancer Inst $1995 ; 87: 52-3$.

135 Mirvish $S$. Effects of vitamin $\mathbb{C}$ and $E$ on $N$-nitroso compound formation, carcinogenesis, and cancer. Cancer 1986;58 Suppl:1842-50.

136 Kyrtopoulos $\mathrm{S}$. Ascorbic acid and the formation of $\mathrm{N}$-nitroso compounds: possible role of ascorbic acti in cancer prevention. Am J Clin Nutr 1987;45:1344-50.

137 Block $\mathrm{G}$. Vitamin $\mathrm{C}$ and cancer prevention: the epidemiologic evidence. Am J Clin Nutr $1991 ; 53: 270$ S-82S.

138 Haenszel $W$, Kurhara $M$, Sigi $M$, Lee $R$. Stomach cancer among Japanese in Hawaii. JNCI 1972;49:969-88.

139 Graham $S_{*}$ Schotz $W$, Martino P. Alimentory factors in the epidemiology of gastric cancer. Cancer 1972;30:927-38.

140 Bjelke $E$. Epidemiological studies of cancer of the stomach, colon and rectum, with special emphasis on the role of diet. Scand J Gastroenterol 1979;9 Suppl:1-235.

141 Ihamaki $T$, Kekki $M$, Sipponen $P$, Siurala $M$. The sequelae and course of chronic gastritis during a 30 to 34 year bioptic follow-up study. Scand J Gastroenterol 1985;20:485-91.

142 Correa $\mathrm{P}$, Haenszel W, Cuello $\mathrm{C}$ et al. Gastric precancerous process in at high risk population: cohort follow-up. Cancer Res 1990;50:4737-40.

143 Villako $K$, Kekki $M$, Maaroos $H$ et al. Chronic gastritis: progression of inflammation and atrophy in a six-year endoscopic follow-up of a randlom sample of 142 Estonian urban subjects. Scand J Gastroenterol 1991;26 (Suppl 186):135-41.

144 Fong T, Dooley $C_{\text {, Dehesa }} \mathrm{M}$ et al. Helicobacter pylori infection in pernicious anaemia: a prospective controlled study. Gastroenterology 1991;100:328-32.

145 Flejou J, Bahane P, Smith A et al. Pernicious anaemia and Campylobacter-like organisms: is the gastric antrum resistant to colonisation? Gut 1989;30:60-4.

146 Gonzalez J, Sancho F, Sainz $S$ et al. Campylobacter pylori and pernicious anaemia. Lancet 1988; i:57.

147 Mardh S, Ma J, Janzon L, Borch K. H,K-ATPase auto-antibodies in patients with pernicious anaemia: Gastroenterology 1994;106:A-729.

148 Houben G, Hooi J, Hameeteman W, Stockbrügger $R$. The frequency of Helicobacter pylori-associated peptic ulcer disease and autoimmune associated conditions in gastric and renal cancer: a retrospective comparison in 267 patients. Eur J Cancer Prev 1994;3 (Suppl 2):75-9.

149 Dayal $\mathrm{Y}$, DeLellis $\mathbb{R}$, Wolfe $H$. Hyperplastic lesions of the gastro-intestinal endocrine cells. Am J Surg Pathol 1987;11 (Suppl 1):87-101.

150 Larsson $H$, Carlsson $E$, Mattson $H$ et al Plasma gastrin and gastric enterochromaffinmlike cell activation and proliferation:studies with omeprazole and ranitidine in intact and antrectomized rats. Gastroenterology 1986;90:391-9.

151 Lechago J, Correa P. Prolonged achlorhydria and gastric neoplasia: is there a causal relationship? Gastroenterology 1993;104:1554-7. 
152 Lind $T$, Cederberg $C$, Forssel $H$ et al. Relationship between reduction of acid secretion and plasma gastrin concentration during omeprazole treatment. Scand $f$ Gastroenterol 1988;23:1259-66.

153 Creutzfeldt W. The achlorhydria-carcinoid sequence: role of gastrin. Digestion 1988;39:61-79.

154 Creutzfeldt $W$, Lamberts $\mathbb{R}$ et al. Inter-relationship between serum gastrin levels, gastric mucosal histology and gastric endocrine cell growth. Digestion 1992;51 (Suppl 1):76-81.

155 Lamberts $\mathrm{R}$, Creutzfeldt $W_{\text {, Struber }} \mathrm{H}$ et al. Longterm omeprazole treatment therapy in peptic ulcer disease: gastrin, endocrine cell growth and gastritis. Gastroenterology 1993; 104:1356-70.

156 Solcia E, Fiocca R, Havu $\mathrm{N}$ et al. Gastric endocrine cells and gastrin in patients receiving long-term omeprazolle treatment. Digestion 1992;51 (Suppl 1):82-92.

157 Hakanson $R$, Chen D, Tielemans $Y$ et al ECL-cells: biology and pathobiology. Digestion 1994;55 (Suppl 3):38-45.

158 Hakanson R, Sundler F. Proposed mechanism of induction of gastric carcinoids: The gastrin hypothesis. Eur J Clin Invest 1990;20 (Suppl 1);65-71.

159 Hodges $J$, Isaacson $\mathbb{P}$, Wright $\mathbb{R}$. Diffuse enterochromaffin-like (ECL) cell hyperplasia and multiple gastric carcinoids: a complication of pernicious anaemia. Gut $1981 ; 22: 237-41$.

160 Borch $\mathrm{K}$, Renval』 $\mathrm{H}$, Liedberg $\mathrm{G}$. Gastric endocrine cell hyperplasia and carcinoid tumours in pernicious anaemia. Gastroenterology 1985;88:638-48.

161 Solcia E, Capella C, Fiocca R et al. Gastric argyrophil carcinoidosis in patients with Zollinger-Ellison syndrome due to Type 1 multiple endocrine neoplasia. A newly recognized association. Am J Surg Pathol 1990;14:503-13.

162 Solcia E, Bordi $C$, Creutzfeldt W et al. Histopathological classification of nonantral gastric endocrine growth in man. Digestion 1988;41:185-200.

163 Helander $H$, Rutgersson $\mathrm{K}$, Helander $\mathbf{K}$. Stereologic investigations of human gastric mucosa. 2. Oxyntic mucosa from patients with Zollinger-Ellison syndrome. Scand J Gastroenterol $1992 ; 27 ; 875-83$.

164 Lehy $T$, Cadiot $M$, Ruszniewski $P$, Bonfils $S$. Influence of multiple endocrine neoplasia type I on gastric endocrine cell in patients with Zollinger-Ellison syndrome. Gut 1992;33:1275-79.

165 Larsson $C$, Skogseid B, Oberg $\mathrm{K}$ et al. Multiple endocrine neoplasia type 1 gene maps to chromosome 11 and lost in insulinoma. Nature $1988 ; 332: 85-7$.

166 Solcia E, Rindi G, Fiocca $R$ et al. Distinct patterns of chronic gastritis associated with carcinoid and cancer and their role in tumorigenesis. Yale $\mathrm{J}$ Biol Med $1992 ; 65: 793-804$.

167 Havu N, Mattson H, Ekman L, Carlsson E. Enterochromaffin cell carcinoids in rat gastric mucosa following long-term administration of ranitidine. Digestion $1990 ; 45: 189-195$. 
168 Poynter $D$, Pick $C$, Harcourt $R$ et al. Association of long lasting unsurmountable histamine $\mathrm{H} 2$ blockade and gastric carcinoid tumours in rat. Gut 1985;26:1284-95.

169 Havu N. Enterochromaffin-like cell carcinoids of gastric mucosa in rats after lifelong unhibition of gastric acid secretion. Digestion 1986;35:42-55.

170 Mattson $\mathrm{H}_{*}$ Havi $\mathrm{N}$, Brautigam $J$ el al. Partial gastric corpectomy results in hypergastrinaemia and development of gastric enterochromaffin-like-cell carcinoids in the rat. Gastroenterology 1991;100:311-9.

171 Lamberts $\mathrm{R}$, Creutzfeldt $\mathrm{W}$, Stockmann $\mathrm{F}$ et al. Long-term omeprazole treatment in man: effects on gastric endocrine cell populations. Digestion 1988;39:126-35.

172 Klinkenberg-Knol E, Festen $H$, Jansen J et al. Long-term treatment with omeprazole for refractory reflux esophagitis: efficacy and safety. Annals of Internal Medicine 1994;121:161-7.

173 D'Adda $T$, Pilato $F$, Lazzaroni $M$ et al. Ultrastructural morphometry of gastric endocrine cells before and after omeprazole. A study in the oxyntic mucosa of duodenall ulcer patients. Gastroenterology 1991;100:1563-70.

174 Waldum $\mathrm{H}$, Haugen $\mathrm{O}$, Isaksen $\mathrm{R}$ et al. Enterochromaffin-like cells in the diffuse but not the intestinal type of gastric carcinomas. Scand J Gastroenterol 1991;26 (Suppl 180): 165-9.

175 Waldum H, Brenna E, Kleveland P, Sandvik A. Gastrin physiological and pathophysiological role: clinical consequences. Dig Dis 1995;13:25-38.

176 Waldum $\mathrm{H}$, Brenna $\mathrm{E}$, Kleveland $\mathrm{P}$ et al. Review article: the use of gastric acidinhibitory drugs - physiological and pathophysiological considerations. Aliment Pharmacol Ther 1993;7:589:96.

177 Modlin I, Tang L. The gastric enterochromaffin-like cell: an enigmatic cellular link. Gastroenterology 1996;111:783-810.

178 Maton P. Risks of hypergastrinaemia. Dig Dis 1995;13:1-2.

179 Solcia E, Villani L, Luinetti O, Fiocca R. Proton pump inhibitors, enterochromaffin-like cell growth and Helicobacter pylori gastritis. Aliment Pharmacol Ther 1993;7 (Suppl 1):25-8.

180 Kuipers E, Lundell L, Klinkenberg-Knol E et al. Atrophic gastritis and Helicobacter pylori infection in patients with reflux esophagitis treated with omeprazole or fundoplication. N Engl J Med 1996;334:1018-22. 


\section{Chapter II}

\section{The frequency of helicobacter pylori associated peptic ulcer disease and of autoimmune- associated conditions in gastric and renal cancer: a retro-spective comparison in 267 patients}

GMP Houben, J Hooi, W Hameeteman, RW Stockbrügger 


\section{Abstract}

Autoimmune atrophic gastritis and associated diseases are known as conditions related to gastric cancer. There is discussion whether Helicobacter pylori (H.pylori) associated gastritis, which is common in peptic ulcer disease (PUD), could be a precursor lesion for the development of gastric cancer. We investigated the frequency of a history of PUD, documented by endoscopy or radiology, and of autoimmune-associated conditions in patients with gastric and renal cancer.

Methods/patients: In a retrospective study the hospital records of 150 patients with gastric cancer $(78 \mathrm{~m}, 72 \mathrm{f}$; mean age $69.1+/-12.0$ (SD) years) were screened for duodenal ulcers (DU), gastric ulcers (GU), peptic ulcers of location not specified, and for the frequency of thyroid diseases, diabetes mellitus, and pernicious anaemia. They were compared with 117 patients with renal cancer $(75 \mathrm{~m}, 42 \mathrm{f}$; mean age $64.5+1-13.9$ (SD) years), who served as controls.

Results: In the gastric cancer group there were 25 patients with peptic ulcers (DU: $n=2$; GU: $n=13$; PU of location not specified: $n=10$ ). In the renal cancer group there were 14 patients with peptic ulcers (DU: $n=6$; GU: $n=2$; PU of location not specified: $n=6$ ). GU was significantly more frequent in patients with gastric cancer compared with renal cancer $(p=0.01)$. Patients with diabetes mellitus and thyroid disease were more frequent in the gastric than in the renal cancer group ( 20 vs. $5(\mathrm{p}=0.01)$ and 9 vs. $1(\mathrm{p}=0.02)$, respectively). One patient with pernicious anaemia was found in the gastric cancer group.

Summary/conclusions: DU (nearly 100\% colonisation with H.pylori) is not, but GU (lower frequency of H.pylori colonisation) is positively correlated to gastric cancer. Autoimmune-associated conditions are significantly more frequent in gastric cancer than in control patients with renal cancer. Autoimmune phenomena appear to be at least as important as H.pylori in gastric carcinogenesis. 


\section{Introduction}

Worldwide well over half a million people die from gastric cancer each year, and in terms of cancer mortality, gastric cancer is second in importance to lung cancer ${ }^{1}$. In the period 1981 - 1986 , there was a more than six - fold difference in international mortality rate from gastric cancer, from $32.2 / 100,000$ males in Japan, to $5.7 / 100,000$ in the USA. Even larger national differences are known ${ }^{2}$.

More remarkable, however, has been the recent consistent decline in incidence in gastric cancer mortality, seen in nearly all countries. In search for the causes of gastric cancer, therefore, we can conclude that causative agents are likely to be widespread, variable in prevalence between populations, and declining in importance, or that protective agents are widespread, variable, and increasing in prevalence $^{3}$.

The stomach occupies a critical position in the digestive tract, as ingested products remain there for a significant amount of time in a relatively crude form. It is therefore easy to imagine that environmental factors, especially ingested carcinogens, co-carcinogens, and protective factors play an important role in gastric carcinogenesis.

\section{Atrophic gastritis}

Atrophic gastritis is known to be one of the precursor lesions in gastric cancer ${ }^{4-9}$. Before the introduction of the Sydney classification, atrophic gastritis was traditionally divided into three types: type $\mathrm{A}$, type $\mathrm{B}$, and type $\mathrm{AB}^{10,11}$.

Type A atrophic gastritis is located in the body and the fundus of the stomach and is associated with achlorhydria or severe hypochlorhydria. This condition can lead to bacterial overgrowth in the stomach, with aerobic and anaerobic flora, enabling the conversion of nitrate to nitrite and further to $\mathrm{N}$-nitroso compounds. $\mathrm{N}$-nitroso compounds constitute one of the most potent carcinogens known to induce gastric cancer, especially the intestinal type of gastric carcinoma ${ }^{12-15}$.

Type A chronic gastritis is frequently associated with the presence of parietal cell antibodies in the serum, and can lead to pernicious anaemia ${ }^{10}$. Helicobacter pylori colonisation is uncommon in type A gastritis ${ }^{16}$.

Type B atrophic gastritis is located predominantly in the antrum of the stomach, 
with the possibility of expanding into the corpus, and is associated with normo- or hypersecretion of gastric acid and with peptic ulceration. So far this type of gastritis had been considered idiopathic, although exogenous irritants such as hot drinks, spices, alcohol, and tobacco, and endogenous irritants like bile reflux, were suggested causes: Nowadays, H.pylori is thought to be the major cause of type B gastritis ${ }^{17}$.

Type $\mathrm{AB}$ atrophic gastritis consists of patchy gastritis in both antral and body mucosa, and is associated with an increased incidence of gastric ulceration, dysplasia, and gastric cancer. A high prevalence of this multifocal gastritis is observed in populations consuming a diet excessive in salty foods and deficient in fresh fruits and fresh leafy vegetables ${ }^{18}$. Patients with this condition have a gradual decrease in hydrochloric acid secretion, and an increase in gastric pH. As a consequence this condition can also lead to bacterial overgrowth. Autoantibodies to parietal cells are not present.

\section{Helicobacter pylori}

Epidemiological, biochemical, morphological and retrospective/prospective followup studies are being performed to study the role of H.pylori as a causative factor in the aetiology of gastric cancer.

Epidemiological studies indicate a moderately increased risk for gastric cancer in H.pylori positive subjects compared with H.pylori-negative controls ${ }^{19.22}$.

In morphological studies, H.pylori seems to be linked to mucosal atrophy and intestinal metaplasia ${ }^{23}$. Intestinal metaplasia was found more often in H.pyloripositive patients than in H.pylori-negative patients. This suggests that H.pylori related gastritis may evolve into intestinal metaplasia. Since the time of colonization with H.pylori appears to be a crucial factor, the occurrence of H.pylori related gastritis at a young age might render an individual at a greater risk for developing intestinal metaplasia and gastric cancer of the intestinal type than those infected with H.pylori at older age or not at all.

One of the biochemical pathways by which H.pylori influences gastric carcinogenesis may be via ascorbic acid ${ }^{24}$. Ascorbic acid, the reduced form of vitamin $\mathrm{C}$, acts as an anti-oxidant, converting nitrite to nitrous oxide, and is therefore potentially important in the prevention of gastric cancer ${ }^{25,26}$. Gastric levels 
of total vitamin C and ascorbic acid are substantially lower in patients with type B chronic gastritis, compared with patients with a normal gastric mucosa. Subjects with hypochlorhydria have significantly lower total vitamin $\mathrm{C}$ concentrations in gastric juice and extremely low ascorbic acid concentrations when compared with subjects with a low $\mathrm{pH}$. Lowered intragastric vitamin C/ascorbic acid levels were also seen in bacterial overgrowth of the stomach and after H.pylori infection. After H.pylori eradication increasing levels were observed.

The strongest evidence for a connection between H.pylori and gastric cancer would be provided by prospective follow-up studies. In such a study by Kuipers et al. ${ }^{27}$, the study population was divided into two groups, H.pylori-negative and H.pyloripositive at the first endoscopic/histological investigation. A progression of gastric atrophy and intestinal metaplasia associated with H.pylori presence was seen at a follow-up endoscopy 11.5 years (mean) later.

\section{Autoimmune disorders}

It has been established that there is a high incidence of atrophic gastritis and pernicious anaemia in patients with autoimmune endocrine disorders such as primary hypothyroidism ${ }^{28,29}$, thyrotoxicosis ${ }^{4.5}$ and idiopathic Addison's disease ${ }^{30}$.

It has long been known that there is more than random coincidence between pernicious anaemia and diabetes mellitus ${ }^{31,32}$. Diabetics frequently have hypochlorhydria or achlorhydria ${ }^{33}$. It also has been shown that insulin-dependent diabetics have a statistically significant over-representation of parietal cell and thyroid antibodies ${ }^{34,35}$.

The aim of this study was to look for possible factors associated with gastric cancer. We investigated the frequency of peptic ulcer disease in patients with gastric cancer, because H.pylori is common in this condition. Furthermore, we investigated the frequency of autoimmune-associated conditions in the same patients.

\section{Patients and methods}

We have retrospectively studied a consecutive series of 267 patients: 150 with gastric cancer ( 78 men and 72 women) and, as controls, 117 with renal cancer ( 75 
men and 42 women), who had their first diagnosis between 1987 and 1991 . The mean age in the renal cancer group was 69.1 years (SD 12.0 years) and in the gastric cancer group 64.5 years (SD 13.9 years) (NS).

We made a survey of hospital records, looking for the following data: age; age at which cancer diagnosis was made; duodenal ulcer in the history; gastric ulcer in the history; peptic ulcer location not specified in the history (the presence of ulcers had to be documented by radiology, endoscopy or at operation); atrophic gastritis; pernicious anaemia; achlorhydria; antibodies against parietal cells; anti-thyroid antibodies; diabetes mellitus; autoimmune thyroid disease; and vitiligo.

The search in the hospital records was done by one of the investigators (JH), who was not biased by a knowledge about the various hypotheses concerning gastric carcinogenesis. The work was supervised by a medical specialist $(\mathrm{GH})$.

Renal cancer patients were chosen as controls, as there are no known common factors in the aetiology of renal and gastric cancer. Furthermore, the prevalence of renal and gastric cancer is similar.

Statistical analysis of differences between the two populations was performed using the Chi-square test.

\section{Results}

The results for peptic ulcer disease are given in Table II.1, and for autoimmune disorders in Table II.2.

Table UI.1 Peptic ulcer disease (percentages) among 150 patients with gastric cancer and 117 patients with renal cancer

\begin{tabular}{lllll}
\hline & Duodenal & Gastric & Peptic ulcer & Total \\
\hline Gastric cancer & $2(1.3)$ & $13(8.6)$ & $10(6.6)$ & $25(16.6)$ \\
Renal cancer & $6(5.1)$ & $2(1.7)$ & $6(5.1)$ & $14(11.9)$ \\
& NS & P $=0.001$ & $\mathrm{NS}$ & $\mathrm{NS}$ \\
\hline
\end{tabular}


Autoimmune disorders among 150 patients with gastric cancer and 117 with renal cancer

\begin{tabular}{lcccccc}
\hline & $\begin{array}{c}\text { Diabetes } \\
\text { mellitus }\end{array}$ & $\begin{array}{c}\text { Thyroid } \\
\text { disease }\end{array}$ & $\begin{array}{c}\text { Pernic. } \\
\text { anaemia }\end{array}$ & $\begin{array}{c}\text { Atroph. } \\
\text { gastr. }\end{array}$ & $\begin{array}{c}\text { Anti- } \\
\text { body }\end{array}$ & Total \\
\hline $\begin{array}{l}\text { Gastric } \\
\text { cancer }\end{array}$ & 20 & 9 & 1 & 2 & 1 & 29 \\
$\begin{array}{l}\text { Renal } \\
\text { cancer }\end{array}$ & 5 & 1 & 0 & 0 & 0 & 6 \\
& $\mathrm{P}=0.01$ & $\mathrm{P}=0.02$ & & & & $\mathrm{P}=0.001$ \\
\hline
\end{tabular}

Gastric ulcers were significantly more common among patients with gastric cancer than patients with renal cancer. For duodenal ulcers there was no significant difference. The proportion gastric/duodenal ulcers in the gastric cancer group was 6.50 and in the renal cancer group, 0.33 .

Patients with diabetes mellitus and thyroid disease were more frequent in the gastric than in the renal cancer group. In the gastric cancer group there were two patients with insulin- dependent diabetes mellitus and 18 with non-insulin-dependent diabetes mellitus. All the five patients with diabetes mellitus in the renal cancer group were non-insulin-dependent diabetics.

In the gastric cancer group there was one patient with hypothyroidism, three patients with a hyperthyroidism, and five patients with toxic multinodular struma colloidalis. The one patient in the renal cancer group had toxic multinodular struma. Pernicious anaemia, antibodies against parietal cells, and atrophic gastritis of type A were only seen in the gastric cancer group, and not in the renal cancer group.

In the gastric cancer group there were two patients who had both thyroid disease and diabetes mellitus; the patient with the pernicious anaemia had antibodies against parietal cells and atrophic gastritis. In total, there were 29 patients with 33 autoimmune conditions.

\section{Discussion}

Until recently, epidemiological, biochemical and morphological studies have given mainly indirect evidence for the role of H.pylori as a causal factor in gastric 
carcinogenesis. A recent prospective follow up study by Kuipers et al ${ }^{27}$ provided some direct evidence that $H$.pylori may be an important factor in the aetiology of atrophic gastritis leading to gastric cancer.

We tried to elucidate to which proportion H.pylori associated conditions and autoimmune phenomena - both suggested to be related to gastric cancer - occurred in a consecutive patient series of gastric cancer, compared with a control population of patients with renal cancer.

The study was retrospective, with all the typical limitations of such a study. However, the study population is large, and it is investigated in a recent period.

In this study the condition which is closest associated with H.pylori (duodenal ulcer) was not correlated with gastric cancer, which seems to exclude a direct carcinogenic effect of the bacterium. Gastric ulcer, which in different studies is associated with H.pylori in $70-80 \%$, was positively correlated to gastric cancer. It is worth noting that in the renal cancer group the gastric/duodenal ulcer rate is that known for the normal population, but in the gastric cancer group it is nearly 20 times higher.

The explanation for this difference is not obvious, and possibilities include: a varying virulence of different $H$.pylori types determining the progression of gastritis; an independent factor that makes antrum gastritis B proceed into pangastritis $\mathrm{AB}$ with gastric ulcer and gastric cancer; or, finally, H.pylori as an epiphenomenon which is more frequent in type $B$ gastritis with high acid secretion compared with type $\mathrm{AB}$ gastritis with normal or low acid secretion.

Autoimmune phenomena have long been associated with gastric cancer. The classic example is pernicious anaemia. Pernicious anaemia and type $A$ gastritis are connected with autoimmune endocrine disorders such as thyroid diseases, idiopathic Addison's disease, and diabetes mellitus. Our study gives evidence that this correlation is still as strong as previously described ${ }^{4,5,28-32,34,35}$.

The general desire for a uniform hypothesis about the pathogenesis of gastric cancer is understandable, and the statistical evidence of H.pylori association has therefore been welcome. However, it appears over-rated. The present study has shown that autoimmune-associated conditions are as frequent as $H$.pylori associated conditions in gastric cancer patients. 
There are many questions to be answered about the aetiopathogenesis of gastric cancer. In order to elucidate the relative importance of various elements, a clinical/pathological investigation of a consecutive series of gastric cancer, similar to that of Kuster et al. ${ }^{36}$, seems to be necessary. Such a study is now underway in our unit. We hope to be able to contribute further information about the relative importance of H.pylori and autoimmune-associated phenomena, respectively, in gastric carcinogenesis. 


\section{References}

1 Parkin $\mathrm{D}_{\text {, Earat }} \mathrm{E}$, Muir C. Estimate of the worldwide frequency of sixteen major cancers in 1980. Int J Cancer 1988;41:184-197.

2 Munoz N. Descriptive epidemiology of gastric cancer. In Reed and Hill, eds, Gastric carcinogenesis, Amsterdam, Excerpta Medica 1988:51-69.

3 Forman D. The etiology of gastric cancer. In: O'Neill, Chen, Bartsch, eds. Relevance to human cancer of $\mathrm{N}$-nitroso compounds, tobacco smoke and mycotoxins, Lyon, International Agency for Research on Cancer 1991:22-32.

4 Siurala $M$, Varis $K$, Wiljasalo $M$. Studies of patients with atrophic gastritis: a 10 15 year follow up. Scand J Gastroenterol 1966;1:40-48.

5 Siurala M, Julkunen H, Lamberg B. Follow-up of patients with atrophic gastritis. Scand J Gastroenterol 1966;1:79.

6 Siurala M, Thamaki T, Lehtola M. Atrophic gastritis and its sequelae. Scand J Gastroenterol 1974;9:441-446.

7 Sipponen $\mathrm{P}$, Kekki $\mathrm{M}$, Haapakoski J et al. Gastric cancer risk in chronic atrophic gastritis: statistical calculations of cross sectional data. Int $J$ Cancer $1985 ; 35: 173-177$.

8 Testoni $\mathrm{P}$, Masci E, Manchi R et al. Gastric cancer in chronic atrophic gastritis. Associated gastric ulcer adds no further risk J Clin Gastroenterol 1987;9:298-302.

9 Tatsuta M, Lishi H, Nakaizumi et al. Fundal atrophic gastritis as a risk factor for gastric cancer. Int J Cancer 1993;53:70-74.

10 Strickland $R$, Mackay I. A reappraisal of the nature and significance of chronic atrophic gastritis. Dig Dis 1973;18:426-440.

11 Glass G, Pitchumoni. Atrophic gastritis. Hum Pathol 1975;6:219-250.

12 Lijinski W. Nitrosamines and nitrosamides in the aetiology of gastrointestinal cancer. Cancer 1977;49:2446-2449.

13 Reed P, Smith P, Haines $K$ et al. Effect of cimetidine on gastric juice $\mathrm{N}$-nitrosamine concentration. Lancet 1981;ii:553-556.

14 Reed P, Smith P, Haines $\mathrm{K}$ et al. Gastric juice $\mathrm{N}$-nitrosamides in health and gastroduodenal disease. Lancet 1981 ;ii:550-552.

15 Tannenbaum S. N Nintroso compounds: a perspective on human exposure. Lancet $1983 ; i: 629-631$.

16 O'Connor $\mathrm{H}$, Axon A, Dixon M. Campylobacter-like organisms unusual in type A (pernicious anaemia) gastritis. Lancet 1984;ii: 1091.

17 Wyatt J, Dixon M. Chronic gastritis, a pathogenic approach. J Pathol 1988;154:113-124.

18 Correa P. Chronic gastritis: A clinico-pathological classification. Am J Gastroenterol 1988;83:504-509.

19 Forman D, Newell D, Fullerton F et al. Association between infection with Helicobacter pylori and risk of gastric cancer: evidence from a prospective investigation. BMJ 1991;302:1302-1305. 
20 Nomura A, Stemmerman G, Chyou $P$ et al. Helicobacter pylori infection and gastric carcinoma among Japanese Americans in Hawaii. $\mathbb{N}$ Engl $J$ Med $1991 ; 325: 1132-1136$.

21 Parsonnet $\mathbf{J}$, Friedman $\mathrm{G}$, Vandersteen $\mathrm{D}$ et al. Helicobacter pylori infection and the risk of gastric carcinoma. $\mathrm{N}$ Engl J Med 1991;325:1127-1131.

22 Talley $\mathbf{N}$, Zinsmeister $\mathrm{A}$, Weaver $\mathrm{A}$ et al. Gastric adenocarcinoma and Helicobacter pylori infection. J Nat』 Cancer Inst 1991;83:1734-1739.

23 Craanen M, Dekker W, Blok P et al. Intestinal metaplasia and Helicobacter pylori. An endoscopic bioptic study of the gastric antrum. Gut 1992;33:16-20.

24 Sobala G, Schorah C, Sandarson M et al. Ascorbic acid in the human stomach. Gastroenterol 1989;97:357-363.

25 Mirvish S. Effects of Vitamin $\mathrm{C}$ and $\mathrm{E}$ on $\mathrm{N}$-nitroso compound formation, carcinogenesis, and cancer. Cancer 1986;58 (Suppl):1842-1850.

26 Kyrtopoulos S. Ascorbic acid and the formation of $\mathrm{N}$-nitroso compounds: possible role of ascorbic acid in cancer prevention. Am J Clin Nutr 1987;45:1344-1350.

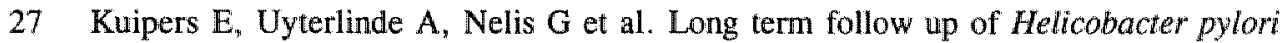
associated gastritis. Gastroenterol 1994;106: A-355.

28 Tudhope G, Wilson G. Anaemia in hypothyroidism. Incidence, pathogenesis, and response to treatment. Quart J Med 1960;29:513.

29 Irvine $W$, Davies $S$, Teitelbaum $S$ et al. Thyroid disease and autoimmunity, Ann $N$ Y Acad Sci 1965; 124:657.

30 Irvine W, Barnes E. Adrenocortical insufficiency. Clin. Endocr. Metab 1972;1:549.

31 Weinberg F. Diabetes mellitus and pernicious anaemia. Amer J Digest Dis 1950;17:398.

32 Sundberg A, Grönberg A. Diabetes mellitus and pernicious anaemia. Acta Med Scand 1960;166:147.

33 Dotevall $G$. Gastric secretion of acid in diabetes melllitus during basal conditions and after maximal histamine secretion. Acta Med Scand 1961;170:59.

34 Whittingham S, Mathews J, Mackay I et al. Diabetes mellitus, autoimmunity and ageing. Lancet $1971 ; 1: 763$.

35 Irvine W. Autoimmunity to thyroid, gastric mucosa and adrenal cortex. In: Bastenie and Gepts (eds). Immunity and autoimmunity in diabetes mellitus. Excerpta Medica, Amsterdam New York, 1974.

36 Kuster G, Remine $W$, Dockerty $M$. Gastric cancer in pernicious anaemia and in patients with and without achlorhydria. Amn Surg 1972;175:783-789. 


\section{Chapter III}

\section{Twenty-four-hour intragastric acidity: $\mathbf{3 0 0} \mathrm{mg}$ ranitidine b.d., $20 \mathrm{mg}$ omeprazole o.m., $40 \mathrm{mg}$ omeprazole o.m. versus placebo}

GMP Houben, J Hooi, W Hameeteman, RW Stockbrügger 


\section{Abstract}

Background: There is considerable controversy about the degree of acid suppression that is optimal for the treatment of peptic disorders.

Aim: To compare the effects of three different regimens that are reported to strongly inhibit acid secretion.

Methods: Intragastric 24-hour pH monitoring was performed in 11 healthy subjects in a randomised, multiple, cross-over, double-blind study. Each subject received four dose regimens, each for 2 weeks, in a random order. The regimens were: $300 \mathrm{mg}$ ranitidine b.d., $20 \mathrm{mg}$ omeprazole $0 . \mathrm{m}$., $40 \mathrm{mg}$ omeprazole $0 . \mathrm{m}$., and placebo.

Results: The decrease in gastric acidity during the daytime and during the total 24-hour period by all three treatments was significantly greater than after placebo; a significant difference in acid inhibition was found between ranitidine and $40 \mathrm{mg}$ omeprazole, but not between ranitidine and $20 \mathrm{mg}$ omeprazole, nor between the two doses of omeprazole. During the night-time the decrease in gastric acidity by all three treatments was significantly greater than after placebo; no difference was seen between the two doses of omeprazole and ranitidine. For the time of $\mathrm{pH}$ greater than 3 we found no statistical difference between the various acid decreasing regimens. The $\mathrm{pH}$ remained significantly longer above 4 after ranitidine and the two doses of omeprazole compared with placebo, and also longer above 4 after $40 \mathrm{mg}$ omeprazole compared with ranitidine, but not after $20 \mathrm{mg}$ omeprazole compared with ranitidine, nor after the two different doses of omeprazole.

Conclusions: Dosing with $300 \mathrm{mg}$ ranitidine b.d., $20 \mathrm{mg}$ omeprazole or $40 \mathrm{mg}$ omeprazole is superior in gastric acid inhibition compared with placebo, when measured using 24-hour pH monitoring. 


\section{Introduction}

Gastro-oesophageal reflux-disease (GORD), gastric ulcer and duodenal ulcer are acid related diseases. Modern acid inhibitory drugs, such as proton pump inhibitors and histamine-2-receptor antagonists, the latter in high doses, are able to profoundly reduce gastric acid secretion ${ }^{1-3}$. The $\mathrm{H}_{2}$-antagonists decrease reduce basal acid secretion effectively but are not potent enough to inhibit meal-stimulated acid secretion, as meals constitute an integrated stimulus for acid secretion, acting through histamine as well as through gastrin and cholinergic receptors ${ }^{4.5}$. Proton pump inhibitors block the final pathway of acid secretion within the parietal cell and are hence effective against all kinds of stimuli for acid secretion ${ }^{6-8}$.

Though many have sought to define the degree of acid suppression that is optimal for the treatment of peptic disorders, there is considerable controversy. Some investigators have attempted to define the degree of acid suppression necessary to achieve the healing of peptic ulcers and reflux oesophagitis", while others have sought to identify the degree of acid suppression which might be associated with potentially adverse effects ${ }^{10}$.

From studies with 24-h monitoring of intragastric $\mathrm{pH}$ we know that the primary determinants of the healing of duodenal ulcers ${ }^{11}$ as well as oesophagitis, are the degree and the duration of acid suppression within the 24-h period ${ }^{12}$. The data from such studies on duodenal ulcer healing suggest that $100 \%$ of duodenal ulcers would heal if a pH $>3$ were maintained for 18 to 20 of the $24 \mathrm{~h}$, and that there is little benefit from more extensive suppression". In GORD, however, the critical $\mathrm{pH}$ threshold is 4 , and more than $80 \%$ of patients with Grade III to IV disease are expected to have their oesophagitis healed within 8 weeks of therapy when the intragastric pH is maintained above 4 for about 16 of $24 \mathrm{~h}$. For $100 \%$ healing it is necessary to elevate the $\mathrm{pH}$ above 4 for approximately 22 of the $24 \mathrm{~h}^{12,43}$. More inhibition of the acid secretion is needed in treatment of GORD compared to duodenal ulcer disease.

More recently there has been an interest in the combination of antisecretory drugs and antibiotics for the eradication of Helicobacter pylori infection, aimed at curing peptic ulcer disease ${ }^{14-16}$. It has been suggested that the $\mathrm{pH}$ threshold for such combination therapy is even higher and should be above $5^{17}$.

On the negative side of strong gastric acid inhibition, the following must be mentioned: the risk of bacterial overgrowth in the proximal digestive $\operatorname{tract}^{18-20}$, and 
hypergastrinaemia with the possibility of ECL-cell hyperplasia and the development of carcinoid tumours ${ }^{21,22}$. Thus, an optimal inhibition of gastric acid secretion has to be found. This means on the one hand providing a high or even $100 \%$ healing rate of the target lesions, but on the other hand avoiding side-effects of such treatment as much as possible. The development of side- effects may depend upon the period of time during which strong acid inhibition is given. For peptic ulcer disease and for Helicobacter pylori eradication " acid inhibition will be given for about 4 weeks, but for GORD, lifelong acid inhibition may be necessary.

Concerning this aspect we evaluated the effects of three different regimens of supposedly strong acid inhibition (300 $\mathrm{mg}$ ranitidine $\mathrm{mg}$ b.d., $20 \mathrm{mg}$ omeprazole o.m., $40 \mathrm{mg}$ omeprazole $\mathrm{o} . \mathrm{m}$.) compared with placebo by means of ambulant 24-hour intragastric $\mathrm{pH}$ monitoring. These drug doses are used as standard therapy in acid-related disorders. With the various ways of acid suppression we also calculated the percentages of time for $\mathrm{pH}$ above 3 and $\mathrm{pH}$ above 4 . To our knowledge, a direct comparison of these three drug regimens has not been published.

\section{Subjects and methods}

This study was a randomized, multiple cross-over, double-blind, single centre study in 11 healthy volunteers ( 7 females, 4 males; age 20-41 years). Each subject received four drug regimens in random order. The regimens were: $300 \mathrm{mg}$ ranitidine b.d., $20 \mathrm{mg}$ omeprazole o.m., $40 \mathrm{mg}$ omeprazole o.m., and placebo. Each regimen lasted for 2 weeks. There were waslh-out periods of 2 weeks between the dosing regimens.

Intragastric acidity was measured by means of a nasogastric antimony electrode connected to a portable Synectics Medical Digitrapper (ED) on the last day of each treatment period, after an overnight fast, starting at 09.00 hours in the morning. The $\mathrm{pH}$ data were stored in a computer using the Gastrosoft EsopHogram software (Synectics) after the 24-h period. A hard copy of the single investigation data was printed immediately after storage. Evaluation of the $\mathrm{pH}$ data was performed using the software Statphac II/pharma, Version January 2nd, 1990 (Synectics).

Electrodes and recorders were calibrated in vitro at $22^{\circ} \mathrm{C}$ using commercial buffer solutions of $\mathrm{pH} 1.07$ and $\mathrm{pH} 7.01$ (Synectics). After calibration, the electrode was passed transnasally and positioned in the body of the stomach. The position of the 
$\mathrm{pH}$ electrode was at $60 \mathrm{~cm}$ from the nostril. After $5 \mathrm{~min} \mathrm{pH}$ was measured: if $\mathrm{pH}$ was less than 6.0 for at least $5 \mathrm{~min}$, the position was accepted; if $\mathrm{pH}$ was more than 6.0 , an abdominal plain film was performed to check the position of the electrode. The distance of the electrode position from the nares was recorded for each subject and kept constant on all test days.

During the test days the subjects were ambulatory throughout the $\mathrm{pH}$ recording and could follow their normal pattern of life. However, meals and drinks were standardized and provided during the 24-h period. Smoking and resting periods had to be recorded on the diary cards by the study subject.

Variables used for calculations were the individual median $\mathrm{pH}$-values covering the entire 24-h period and for the episodes from 9.00 to 24.00 hours and from 0.00 to 06.00 hours, respectively. Furthermore, the fraction of the total recording period with a $\mathrm{pH}$ above 3 and above 4 were calculated.

Statistical analysis was performed using the Friedman's two-way analysis of variance by ranks with Bonferroni correction; further, the Wilcoxon signed ranks test was used to examine paired or unpaired differences; $\mathrm{P}<0.05$ was considered to be significant.

The study was approved by the Ethics Committee of the Academic Hospital Maastricht, and written informed consent was obtained from each subject, prior to entering the study.

\section{Results}

A total of 12 healthy volunteers started the study. After the first study period one volunteer decided not to participate any further in the study, because of a sore throat during 24-h pH measurement. All the other subjects tolerated the experiments well, and no adverse reaction was reported. The group median values of the individual median intragastric $\mathrm{pH}$ values during the four different dosing regimens are given in Table III.1, for the total 24 -h period, the daytime period from 09.00 to 24.00 hours, and the night-time period from 0.00 to 06.00 hours.

\section{Daytime measurement}

During the daytime period the decrease in gastric acidity was significantly stronger after ranitidine $(\mathrm{P}<0.05), 20 \mathrm{mg}$ omeprazole $(\mathrm{P}<0.001)$ and $40 \mathrm{mg}$ omeprazole $(\mathrm{P}<0.001)$ administration compared with placebo. We found no statistically 
significant difference in the decrease in gastric acidity between the effect of ranitidine and $20 \mathrm{mg}$ omeprazole $(P=0.08)$, however between ranitidine and $40 \mathrm{mg}$ omeprazole we found a statistically significant difference in the decrease in gastric acidity $(P=0.01)$. Furthermore we found no difference between omeprazole $20 \mathrm{mg}$ and omeprazole $40 \mathrm{mg}$ in inhibiting gastric acidity.

Table III. 1: Median values and ranges for the $24 \mathrm{mr}$ period, night-thme, and daytime. $P$ values indicatic overall significancy with Manova

\begin{tabular}{|c|c|c|c|c|c|}
\hline & Placebo & $\begin{array}{l}\text { Ramitidine } \\
300 \mathrm{mg} \text { bid }\end{array}$ & $\begin{array}{l}\text { Omeprazole } \\
20 \mathrm{mg} \mathrm{om}\end{array}$ & $\begin{array}{l}\text { Omeprazolle } \\
40 \mathrm{mg} \text { om }\end{array}$ & $\mathbf{P}$ \\
\hline $\mathrm{pH} 9.24 \mathrm{hr}$ & $1.7(0.9-5.6)$ & $3.2(1.9-6.8)^{\mathrm{a}}$ & $5.1(1.3-8.8)^{b}$ & $6.0(2.3-7.2)^{b, c}$ & $<0.001$ \\
\hline $\mathrm{pH} \mathrm{0-6} \mathrm{hr}$ & $1.7(0.9-5.6)$ & $3.9(1.2-8.5)^{d}$ & $4.9(1.4-8.8)^{e}$ & $4.5(1.6-7.7)^{*}$ & $<0.01$ \\
\hline ph $24 \mathrm{hrs}$ & $1.7(0.9-4.2)$ & $3.7(1.9-6.8)^{4}$ & $4.5(1.4-7.6)^{6}$ & $5.5(2.1-7.1)^{b .5}$ & $<0.01$ \\
\hline
\end{tabular}

${ }^{-P}<0.05$ compared to placebo; ${ }^{\circ} \dot{P}<0.001$ compared to placebo;

P $\mathbf{P}<0.01$ compared to ranitidine; ${ }^{\prime} \mathbf{P}<0.01$ compared to placebo;

" $\mathrm{P}<0.005$ compared to placebo" " $\mathrm{P}<0.05$ compared to ranitidine.

\section{Nighttime measurement}

During the night-time period the decrease in gastric acidity by all three treatments was stronger than after placebo $(20 \mathrm{mg}$ and $40 \mathrm{mg}$ omeprazole: $\mathrm{P}<0.005$; ranitidine: $\mathrm{P}=0.01$ ). No significant difference was seen between the two doses of omeprazole and ranitidine.

\section{Total 24-h (daytime and night-time) measurement}

The decrease in overall 24-h gastric acidity was significantly stronger after ranitidine $(\mathrm{P}<0.01), 20 \mathrm{mg}$ omeprazole $(\mathrm{P}=0.001)$ and $40 \mathrm{mg}$ omeprazole $(\mathrm{P}<0.001)$ than after placebo. We found no statistically significant difference in acid inhibition between ranitidine and $20 \mathrm{mg}$ omeprazole $(P=0.15)$, however between ranitidine and $40 \mathrm{mg}$ omeprazole we found a statistically significant difference in acid inhibition $(\mathrm{P}<0.05)$. Once again we found no significant statistical difference between the two doses of omeprazole. 
The median 24-h pH curves of the four treatments are given in Figure III. 1a to III. Id, illustrating amongst others that there seems to be a "physiological" dip in gastric $\mathrm{pH}$ between midnight and early morning hours independent of the type of medication.

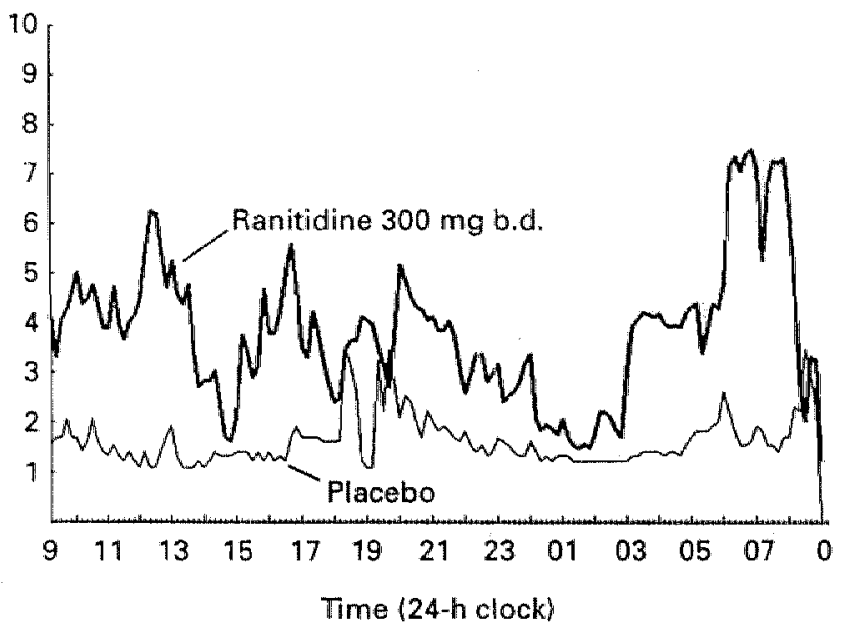

Figure III.1a: Median 24-H pH curves for placebo and ranitidine $300 \mathrm{mg}$ b.i.d.

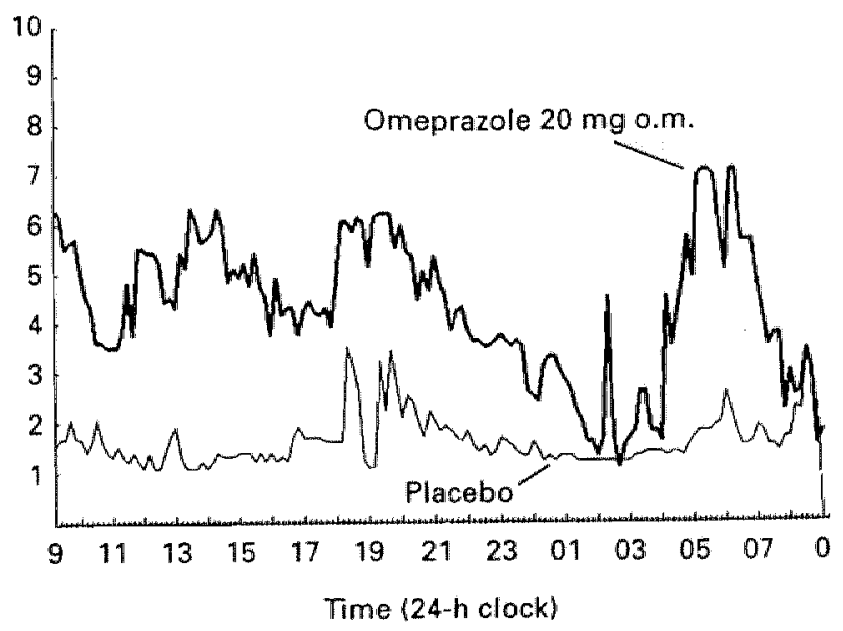

Figure III.1b: Median 24-H pH curves for placebo and omeprazole $20 \mathrm{mg} \mathrm{o.m.}$ 


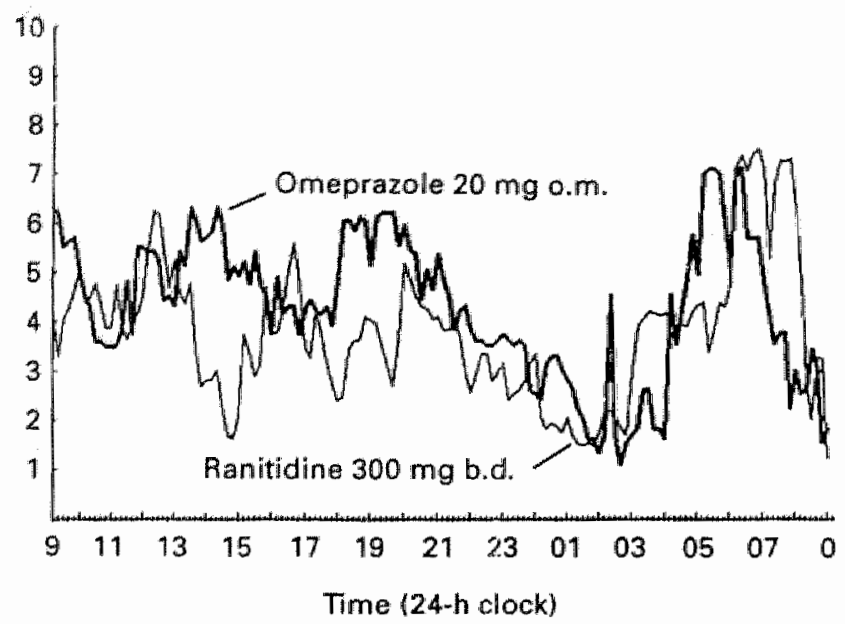

Figure III.1c: Median 24-H pH curves for ranitidine $300 \mathrm{mg}$, b.i.d, and omeprazole $20 \mathrm{mg} 0 . \mathrm{m}$.

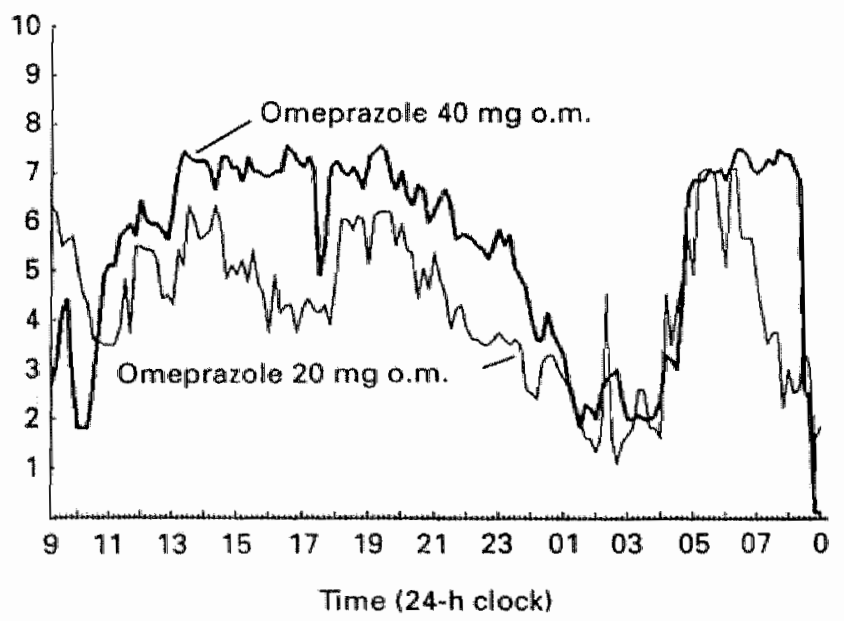

Figure III.1d: Median 24-H pH curves for omeprazole $20 \mathrm{mg} \mathrm{0.m.} \mathrm{and}$ omeprazole $40 \mathrm{mg}$ o.m. 
The median percentages of time for intragastric $\mathrm{pH}$ above 3 and $\mathrm{pH}$ above 4 are given in Table III.2. We found no statistically significant difference between the various treatments including placebo for the proportion of time $\mathrm{pH}$ above 3 . However, the results were statistically different from each other $(P<0.005)$ for the percentage of time $\mathrm{pH}$ above 4 : the $\mathrm{pH}$ remained significantly longer above 4 after ranitidine and $20 \mathrm{mg}$ omeprazole $(P<0.005)$, and $40 \mathrm{mg}$ omeprazole $(P<0.001)$ than after placebo. The $\mathrm{pH}$ was significantly longer above 4 after $40 \mathrm{mg}$ omeprazole than after ranitidine $(\mathrm{P}<0.05)$, but not after $20 \mathrm{mg}$ omeprazole compared with ranitidine $(\mathrm{P}=0.15)$. Once more there was no difference between the two doses of omeprazole.

Table III.2: $\quad$ Median values and ranges (percentages) $\mathrm{pH}$ above 3 and 4. $\mathrm{P}$ values indicate overail significancy with Manova. For the differences between the various treatments: see RESULTS.

\begin{tabular}{cccccc}
\hline & Placebo & $\begin{array}{c}\text { Ranitidine } \\
\text { 300 } \mathbf{~ m g ~ b i d ~}\end{array}$ & $\begin{array}{c}\text { Omeprazole } \\
\mathbf{2 0} \mathbf{~ m g ~ o m ~}\end{array}$ & $\begin{array}{c}\text { Oneprazole } \\
\mathbf{4 0} \mathbf{~ m g ~ o m ~}\end{array}$ & P \\
\hline $\mathrm{pH}>3$ & $18.3(7.9-99.5)$ & $59.1(21.6-100)$ & $65.2(18.7-100)$ & $78.7(34.2-100)$ & NS \\
$\mathrm{pH}>4$ & $11.4(3.0-69.1)$ & $40.4(9.2-100)$ & $55.9(10.3-94.6)$ & $68.0(22.1-97.2)$ & $<0.01$ \\
\hline
\end{tabular}

\section{Discussion}

The variety of drugs inhibiting acid secretion is large. Nowadays a number of histamine-2-receptor antagonists and proton pump inhibitors are used in clinical practice. Efficacy of the different drugs determines the choice in case of a specific disease. The acid inhibiting capacity of drugs in various doses is measured by secretion tests, of which the $24-\mathrm{h} \mathrm{pH}$ monitoring reflects the state of gastric acid secretion the most accurately ${ }^{13,23}$.

Recently a number of studies of patients with oesophagitis or peptic ulcer disease and of healthy volunteers have been reported, in which 24-h $\mathrm{pH}$ monitoring was applied during treatment with various doses of the acid inhibiting drugs, similar to those used in this study ${ }^{2-5,24-27}$. Chiverton et al. ${ }^{2}$ compared the effect of placebo with $20 \mathrm{mg}$ omeprazole, given either in the morning or in the evening, on 24-h gastric acidity in duodenal ulcer patients. The $24-\mathrm{h}$ mean $\mathrm{pH}$ for placebo, omeprazole morning dosing, and omeprazole evening dosing were: $1.7,3.9(\mathrm{P}<0.01)$ and 2.9 (N.S.). Patel et al. ${ }^{3}$ studied the effects of $300 \mathrm{mg}$ ranitidine at night and $300 \mathrm{mg}$ 
ranitidine twice daily on 24 -h intragastric acidity in a placebo-controlled study in healthy subjects. There was a significant increase in median intragastric $\mathrm{pH}$ during treatment with ranitidine: from 1.4 to $2.8(300 \mathrm{mg}$ at night, $\mathrm{P}<0.01)$ and 3.8 ( $300 \mathrm{mg}$ twice daily, $P<0.01$ ). No difference in decrease of nocturnal acidity was seen between the two different doses of ranitidine. Daytime acidity was reduced only $45.4 \%$ after $300 \mathrm{mg}$ ranitidine at night, compared with $75.6 \%$ after ranitidine $300 \mathrm{mg} \mathrm{b.d}$ :

Lind et al..$^{5}$ compared the decrease in intragastric acidity during treatment with either $40 \mathrm{mg}$ omeprazole in the morning or $300 \mathrm{mg}$ ranitidine twice daily in patients with reflux oesophagitis. Omeprazole decreased 24 -h intragastric acidity by $96 \%$ and ranitidine by $66 \%(\mathrm{P}<0.001)$. Omeprazole decreased intragastric acidity equally during daytime $(99 \%)$ as during night-time $(95 \%)$, whereas ranitidine showed a different pattern, with a decrease of intragastric acidity during daytime of $57 \%$ vs. $76 \%$ during night-time, comparable with the results of Patel et al. In accordance with these results we also found that the decrease in gastric acid secretion after ranitidine, given twice daily, was most marked at night.

Merki et al. ${ }^{25-27}$ and Savarino et al..$^{28}$, comparing the effect of various histamine-2receptor antagonists and placebo on intragastric acidity in healthy volunteers and duodenal ulcer patients, found a decrease in the median 24-h acidity from $79.4 \mathrm{mmol} / 1$ on placebo to $3.6 \mathrm{mmol} / 1$ on $300 \mathrm{mg}$ ranitidine b.d. ${ }^{27}$. Walt et al. comparing the effect of $150 \mathrm{mg}$ ranitidine b.d. and $300 \mathrm{mg}$ ranitidine b.d. on intragastric acidity in duodenal ulcer patients found no difference between these two doses ${ }^{29}$. The rise in median $24-\mathrm{h} \mathrm{pH}$ with $300 \mathrm{mg}$ ranitidine b.d. in our study from 1.7 to 3.7 is similar to that reported by Merki et al. ${ }^{27}$;

We found, in agreement with others ${ }^{2,5}$, that omeprazole decreased gastric acidity during both daytime and night-time. However, in absolute terms inhibition was stronger during the day (median $\mathrm{pH}$ after $20 \mathrm{mg}$ omeprazole and $40 \mathrm{mg}$ omeprazole, respectively, during daytime 5.1 and 6.0 and during night-time 4.9 and 4.5 ). Similarly Chiverton et al. ${ }^{2}$ showed that $20 \mathrm{mg}$ orneprazole given in the morning gives a mean morning $\mathrm{pH}$ of 4.2 , a mean afternoon $\mathrm{pH}$ of 4.6 , a mean evening $\mathrm{pH}$ of 3.7 , and a mean nocturnal $\mathrm{pH}$ of 3.7 . In our study the median $\mathrm{pH}$ during night-time did not reach $\mathrm{pH} 5$, neither with $20 \mathrm{mg}$ omeprazole nor with $40 \mathrm{mg}$ omeprazole given once daily. When giving omeprazole $20 \mathrm{mg}$ or $40 \mathrm{mg}$ twice daily Labenz et al. ${ }^{24}$ found a continuous rise in $\mathrm{pH}$ above 5 . We found no significant difference in acid inhibition between the two different doses of omeprazole given o.m., neither did Labenz et al. ${ }^{24}$ in the recent report concerning omeprazole $20 \mathrm{mg} \mathrm{b.d.} \mathrm{and} 40 \mathrm{mg}$ b.d. in duodenal and gastric ulcer patients. 
Therapeutically the consequence seems to be that, in patients with severe peptic ulcer disease or reflux oesophagitis, omeprazole should preferably be given twice daily instead of doubling the morning dose.

By using Burget's criteria from meta-analysis concerning optimal dosing of antisecretory drugs in healing acid-related disorders ${ }^{9}$, we found out that the decrease in gastric acid secretion achieved with $300 \mathrm{mg}$ ranitidine twice daily or $20 \mathrm{mg}$ omeprazole $0 . \mathrm{m}$. is not sufficient for the $100 \%$ healing of peptic ulcers within 4 weeks as indicated. However, $40 \mathrm{mg}$ omeprazole in the morning fulfils these criteria.

Bell et $\mathrm{al}^{12}$ indicated in their meta-analysis that there is a correlation between the healing rate of oesophagitis and the time that the intragastric $\mathrm{pH}$ is maintained above 4: for a $80 \%$ healing within 8 weeks the pH should be kept above 4 for 16 of every $24 \mathrm{~h}$ ( $66 \%$ of time). For a $100 \%$ healing it is necessary to obtain the $\mathrm{pH}$ above 4 for more than $22 \mathrm{~h}$. As our results show, the decrease in gastric acid secretion achieved with $300 \mathrm{mg}$ ranitidine twice daily or $20 \mathrm{mg}$ omeprazole o.m. is suboptimal for the treatment of moderate or severe reflux oesophagitis, which is also illustrated by the clinical results of Lundell et al. ${ }^{30}$. Again, our study shows that with a pH above 4 during $68 \%$ of the $24 \mathrm{~h}, 40 \mathrm{mg}$ omeprazole would result in healing $80 \%$ of the time, but not $100 \%{ }^{12}$.

From the studies mentioned above it is clear that to maintain intragastric $\mathrm{pH}$ above 5 , needed for the eradication of Helicobacter pylori, such a strong and prolonged acid inhibition can only be obtained by omeprazole given twice daily. The results of our study and of other studies mentioned above are important as they give an indication for the possible result of therapy in the treatment of peptic ulcer disease and oesophageal reflux disease.

We have only dealt with the effect of ranitidine and omeprazole on gastric acid secretion. Further comparisons of these drug doses need to be performed on the possible side-effects of acid inhibition, such as bacterial overgrowth and hypergastrinaemia. Defining a dose range, which on one hand gives a sufficient decrease in gastric acid secretion, and on the other hand avoids major interference with physiological mechanisms, would be desirable. 


\section{References}

1 Sharma BK, Walt RP, Pounder RE et al. Optimal dose of oral omeprazole for maximall 24 hour decrease of intra-gastric acidity. Gut 1984:25:957-964.

2 Chiverton SG, Howden CW, Burget DW, Hunt RH. Omeprazole (20 mg) daily given in the morning or evening: a comparison of effects on gastric acidity, and plasma gastrin and omeprazole concentration. Aliment Pharmacol Therap $1992 ; 6 \times 103-111$.

3 Patel $N$, Ward UM, Brown AK et al. The effect of ranitidine $300 \mathrm{mg}$ at night, ranitidine $300 \mathrm{mg}$ twice daily and placebo on 24 -h intragastric $\mathrm{pH}$ and 24 -h plasma gastrin in healthy subjects. Eur J Gastroenterol Hepatol 1993,5:161-164.

4 Lanzon-Miller S, Pounder RE, Hamilton et al. Twenty-four-hour intragastric acidity and plasma gastrin concentration before and during treatment with either ranitidine or omeprazole. Aliment Pharmacol Therap 1987;1:239-251.

5 Lind T, Cederberg C, Idström et al. 24-hour intragastric acidity and plasma gastrin during long-term treatment with omeprazole or ranitidine in patients with reflux esophagitis. Scand J Gastroenterol 1991;26:620-626.

6 Lindberg P, Nordberg P, Alminger $T$ et al. The mechanism of action of the gastric acid secretion inhibitor omeprazole. J Med Chem 1986;29:1327-1329.

7 Lind $T$, Cederberg C, Ekenved $G$ et al. Effect of omeprazole - a gastric protonpump inhibitor on pentagastrin stimulated acid secretion in man. Gut $1983 ; 24: 270-276$.

8 Lind $\mathbb{T}$, Cederberg $\mathrm{C}$, Ekenved $\mathrm{G}$ et al. Inhibition of basal and betazole- and shamfeeding induced acid secretion by omeprazole in man. Scand $J$ Gastroenterol $1986 ; 21: 1004-1010$.

9 Burget DW, Chiverton SG, Hunt RH. Is there a optimal degree of acid suppression for healing of duodenal ulcers? Gastroenterology 1990;99:345-351.

10 Verdu E, Viani F, Armstrong D et al. Effect of omeprazole on intragastric bacterial counts, nitrates, nitrites, and $\mathrm{N}$-nitroso compounds. Gut 1994;35:445 460 .

11 Jones DB, Howden $C W$, Burget DW et al. Acid suppression in duodenal ulcer: a meta-analysis to define optimal dosing with antisecretory drugs. Gut 1987;28: $1120-1127$.

12 Bell $\mathrm{NJ}$, Burget D, Howden $\mathrm{C}$ et al. Appropriate acid suppression for the management of gastro-oesophageal reflux disease. Digestion 1992;51 (Suppl 1): 59-67.

13 Pounder RE, Fraser AG. Gastric acid secretion and intragastric acidity: measurement in health and disease. Baillieres Clin Gastroenterol 1993;7(1):55-80.

14 Bayerdörffer $E$, Mannes $G$, Sommer $A$ et al. High dose omeprazole treatment combined with amoxicillin eradicates Helicobacter pylori. Eur J Gastroenterol Hepatol. 1992;4:697-702. 


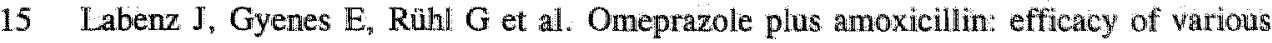
treatment regimens to eradicate Hellicobacter pylori. Am I Gastroenterol $1993 ; 88: 491-495$.

16 Unge $\mathrm{P}$, Gad A, Eriksson $\mathrm{K}$ et al. Amoxicillin added to omeprazole prevents relapse in the treatment of duodenal ulcer patients. Eur $J$ Gastroenterol Hepatol $1993 ; 5: 325-331$.

17 Hunt RH. $\mathrm{pH}$ and Hp, gastric acid secretion and Helicobacter pylori: implications for ulcer healing and eradication of the organism. Am $J$ Gastroenterol $1993 ; 88: 481-483$.

18 Howden CW, Hunt RH. Relationship between gastric secretion and infection. Gut 1987;28:96-107.

19 Stockbrügger RW, Cotton PB, Eugenicles $\mathrm{N}$ et al. Intragastric nitrites, nitrosamines, and bacterial overgrowth during cimetidine treatment. Gut 1982;23:1048-1054.

20 Houben G, Stockbrügger RW. Bacteria in the aetio-pathogenesis of gastric cancer. Scand J Gastroenterol 1995;30 Suppl 212:13-18.

21 Borch $\mathrm{K}$, Rewall $\mathrm{H}$, Lieberg $\mathrm{G}$. Gastric endocrine cell hyperplasia and carcinoid tumors in pernicious anaemia. Gastroenterology $1985 ; 88: 638-648$.

22 Harvey RF, Bradshaw MJ, Davidson CM et al. Multi-focal gastrin carcinoid tumours, achlorhydria, and hyper-gastrinaemia. Lancet 1985;1:951-953.

23 Pounder RE, Lanzon-Miller S, Smith JT et al. Royal Free Hospital protocol for 24-hour intragastric acidity and plasma gastrin concentration. Dig Dis 1990;8 Suppl 1:10-17.

24 Labenz J, Jorias I, Sollböhmer M et al. Gastrale 24-Stunden-pH-Profile unter 2 x $20 \mathrm{mg}$ und $2 \times 40 \mathrm{mg}$ Omeprazol bei Patienten mit Helicobacter-pylori-assozierter gastro-duodenaler Ulkuskrankheit. Z Gastroenterol 1994;32:436-440.

25 Merki HS, Witzel L, Walt RP et al. Double blind comparison of the effects of cimetidine, ranitidine, famotidine, and placebo on intragastric acidity in 30 normal volunteers. Gut 1988;29:81-84.

26 Merki HS, Fimmel CJ, Walt RP et al. Pattern of 24-hour intragastric acidity in active duodenal ulcer disease and in healthy controls. Gut $1988 ; 29: 1583 * 1587$.

27 Merki HS, Witze] $\mathbb{L}$, Walt RP et al. Comparison of ranitidine $300 \mathrm{mg}$ twice daily, $300 \mathrm{mg}$ at night and placebo on 24-hour intragastric acidity of duodenal ulcer patients. Aliment Pharmacol Therap 1987;1:217-223.

28 Savarino V, Mela G, Scalabrini $\mathrm{P}$ et al. Continuous 24-hour intragastric pH monitoring in the evaluation of the effect of a nightly dose of famotidine, ranitidine and placebo on gastric acidity of patients with duodenal ulcer. Digestion $1987 ; 37: 103-109$.

29 Walt RP, Male P-J, Rawlings $J$ et al. Comparison of the effects of ranitidine, cimetidine and placebo on the 24 hour intragastric acidity and nocturnal acid secretion in patients with duodenal ulcer. Gut 1981;22:49-54. 
30 Luindell L, Backman L, Ekstrom $P$ et al. Omeprazole or high-dose ranitidine in the treatment of patients with reflux oesophagitis not responding to "standard doses" of H2-receptor antagonists. Aliment Pharmacol Therap 1990;4:145-155. 


\section{Chapter IV}

\section{Intragastric bacterial growth, nitrates, nitrites and $\mathbf{N}$-nitroso compounds after $300 \mathrm{mg}$ ranitidine b.d., $20 \mathrm{mg}$ omeprazole, $40 \mathrm{mg}$ omeprazole and placebo}

GMP Houben, J Hooi, R-JM Brummer, EE Stobberingh, RW Stockbrügger 


\section{Abstract}

Background: Decreased gastric acidity is known to cause intragastric bacterial colonisation and increase of intragastric nitrite and $\mathrm{N}$-nitroso compound (NOC) concentrations.

Aim: We evaluated the effects of three regimens of acid inhibition in a double-blind, placebo-controlled multiple cross-over study to elucidate the mechanisms leading to the formation of $\mathrm{N}$-nitroso compounds.

Methods: Intragastric 24-hour $\mathrm{pH}$ monitoring, and gastric juice sampling for bacteriological culture and determination of nitrate, nitrite and NOC concentrations were performed in 11 healthy subjects. Each subject received $300 \mathrm{mg}$ ranitidine b.d., $20 \mathrm{mg}$ omeprazole o.m. $40 \mathrm{mg}$ omeprazole o.m., and placebo, for 2 weeks.

Results: $300 \mathrm{mg}$ ranitidine b.d., $20 \mathrm{mg}$ omeprazole and $40 \mathrm{mg}$ omeprazole all decreased 24-hour gastric acidity significantly when compared to placebo, $40 \mathrm{mg}$ omeprazole significantly more than $300 \mathrm{mg}$ ranitidine b.d. All three acid inhibiting treatments resulted in a significant and similar increase of the bacterial flora in the gastric juice, mainly of Gram-positive bacteria. For the nitrate, nitrite and NOC concentrations, no differences were found. Positive correlations were found between decrease of intragastric acidity and bacteria, between bacteria and nitrite, and between nitrite and NOC formation. No direct correlations were found between reduction of intragastric acidity and formation of nitrites. Nitrosation of amines was favoured by normal intragastric acidity.

Conclusions: Both moderate and profound acid inhibition lead to bacterial nitrate reduction. Intragastric nitrite concentration is the determining factor for the nitrosation of amines, which in man can occur at physiological $\mathrm{pH}$ levels. 


\section{Introduction}

Gastro-oesophageal reflux disease (GORD), gastric ulcer and duodenal ulcer are acid related diseases. Modern drugs, such as histamine-2-receptor antagonists (H2RAs) and proton pump inhibitors (PPI), give moderate to profound inhibition of gastric acid secretion ${ }^{1-3}$.

There is still considerable controversy about the degree of acid suppression which is optimal for the treatment of peptic disorders. Although gastric acid in man is not essential to life, it is important for many digestive processes such as the activation of pepsinogens, the absorption of dietary iron and calcium, and the stimulation of pancreatic secretion ${ }^{4}$. Furthermore gastric acid is an important primary bactericidal barrier to protect the small intestine against microbial contamination ${ }^{5-7}$.

Decreased gastric acidity because of age ${ }^{8}$, gastric surgery ${ }^{9,10}$, or the administration of antacids ${ }^{11,12}, \mathrm{H} 2$-receptor antagonists ${ }^{9.11,13,14}$, and proton pump inhibitors ${ }^{15,16}$ has previously been reported to increase gastric bacterial colonisation and this has been proposed to induce the formation of potentially carcinogenic $\mathrm{N}$-nitroso compounds $(\mathrm{NOC})^{14,15,17-19}$.

Optimal therapeutic inhibition of gastric acid secretion should confer high healing rates of the target lesions and avoid treatment-associated adverse effects, particularly in long-lasting treatment.

In most previous studies intragastric bacterial overgrowth was related to momentary intragastric $\mathrm{pH}$. In this study the effect of $300 \mathrm{mg}$ ranitidine b.d., $20 \mathrm{mg}$ omeprazole o.m., $40 \mathrm{mg}$ omeprazole o.m., and placebo, on intragastric bacteria and intragastric concentrations of NOCs and their precursors nitrate and nitrite were related to 24-hour intragastric $\mathrm{pH}$-profilles, in order to evaluate the potential negative side-effects of profound acid inhibition. Furthermore we wanted to elucidate which intragastric factors determined the formation of NOC. To our knowledge, a direct comparison of the effects and side-effects of these three drugregimens has not been published so far.

\section{Subjects and methods}

This study had a randomised, multiple cross-over, double-blind, single centre design. Eleven healthy volunteers ( 7 females, 4 males; age 20-41 years) 
participated. Each subject received four courses of treatment in random order: $300 \mathrm{mg}$ ranitidine b.d., $20 \mathrm{mg}$ omeprazole o.m. postprandial, $40 \mathrm{mg}$ omeprazole o.m. postprandial, and placebo. Each treatment period lasted for two weeks. Between the treatment periods, wash-out periods of two weeks were maintained.

\section{Test procedure}

In the morning of the last day of each treatment period, after overnight fasting, a throat swab was taken for microbiological culture. Thereafter a nasogastric tube was positioned with its tip in the gastric body, and a gastric juice sample of at least $2 \mathrm{ml}$ was aspirated for microbiological and biochemical investigations. If the amount of the sample did not exceed $10 \mathrm{ml}$, the sample volume was diluted up to $10 \mathrm{ml}$, and a correction factor was used for the final calculation of the concentrations.

\section{Microbiology}

After sampling, throat swabs and gastric juice were immediately transported to the bacteriological laboratory and processed within two hours. Throat swabs were rubbed - while rotating - over about one third of the surface of each of two agar plates, i.e. a blood agar plate for total bacterial count, and a selective agar plate for staphylococci and streptococci only, and further diluted with a sterile loop. The plates were incubated aerobically at $37^{\circ} \mathrm{C}$ for two days. The presence of microorganisms was reported semiquantitatively as,,++++++ , or no growth.

Gastric juice samples were diluted $1: 100$ and $1: 10000$ in phosphate buffered saline. Dilutions of the gastric juice samples $(1 \mu \mathrm{l}, 10 \mu \mathrm{l}, 100 \mu 1)$ as well as the undiluted samples were streaked out over one third of each of six agar plates and further diluted with a sterile loop. The agar plates comprised a blood agar plate for the total bacterial count, a CLED agar plate for Gram negative rods, and selective plates for yeasts, Pseudomonas, staphylococci/streptococci and for Helicobacter pylori. For the last species a CAM/CHOC agar plate was used, which was incubated under microaerophilic conditions (carbon dioxide 10\%, oxygen $5 \%$ ) at $37^{\circ} \mathrm{C}$ for $4-7$ days. All other plates were incubated aerobically at $37^{\circ} \mathrm{C}$ for 2 days.

Bacterial growth was assessed quantitatively as $\log _{10}$ colony forming units (cfu) per $\mathrm{ml}$ gastric juice, with a lowest detection limit of $10^{1} \mathrm{cfu} / \mathrm{ml}$ and an upper detection limit of $10^{7} \mathrm{cfu} / \mathrm{ml}$.

For the identification of the microorganisms standard microbiological methods were used. For the analysis of the micro-biological data, microorganisms were 
subdivided in Gram positive and Gram negative, further identified onto the species level, and finally grouped into "faecal-jike" (i.e. enterobacteraecae, faecall enterococci) and "throat-like" (i.e. streptococci, staphylococci) bacteriae.

\section{Biochemistry}

Gastric juice samples of $5 \mathrm{ml}$ were kept in tubes containing $0.2 \mathrm{ml} \mathrm{NaOH} 10 \mathrm{~mol} / \mathrm{l}$ as a conservating agent. The samples were immediately deep frozen in liquid mitrogen and stored at $-80^{\circ} \mathrm{C}$.

Nitrates were measured (BCO, Breda, The Netherlands) by reduction to NO, removal of this in a stream of argon and quantification by a thermal energy analysis detector based on the chemi-luminescent reaction with ozone $\mathrm{e}^{20}$. Nitrite was measured by acidification and quantifying the evolved $\mathrm{NO}$ as above ${ }^{20}$. Nitrate and nitrite concentrations were expressed as $\mu \mathrm{mol} / 1$. The upper normal limit of nitrite was $15 \mu \mathrm{mol} / 1$.

For estimations of total NOCs, further gastric juice samples of $5 \mathrm{ml}$ were obtained in tubes containing amidosulfonic acid $\left(\mathrm{H}_{2} \mathrm{~N}-\mathrm{SO}_{3} \mathrm{H}\right) 2 \%$ (weight/volume). The samples were immediately deep frozen in liquid nitrogen and stored at $-80^{\circ} \mathrm{C}$. Measurements were performed by CERBIA Laboratory Douai, France, within 5 days, with the method previously described by Pignatelli ${ }^{21}$, by denitrosating with $\mathrm{HBr}$, drawing off the $\mathrm{NO}$ and measuring this as described above. Interference by nitrite was avoided by pre-treatment of the samples with sulphanic acid which destroys the nitrite; interference by nitrate was avoided by the presence of sulphanilic acid in the denitrosation system. Volatile $\mathrm{N}$-nitrosamines were measured by extracting them into organic solvent, and gas-chromatography with thermal decomposition of the nitrosamines, as they emerge from the chromatogram to $\mathrm{NO}$, which was quantitated as above. Some non-volatile nitrosamines could be estimated, if required, by converting them to volatile derivatives and treating these as volatile nitrosamines. The upper limit of normal for the NOC concentrations was $1.8 \mu \mathrm{mol} / \mathrm{l}$.

\section{4-hour pH-monitoring}

After gastric juice aspiration, intragastric $\mathrm{pH}$ was measured by means of nasogastric antimony electrodes connected to a portable $\mathrm{pH}$ Synectics Medical Digitrapper (ED). After the 24-hour monitoring period the $\mathrm{pH}$ data were stored in a computer using the Gastrosoft EsopHogram software (Synectics). Evaluation of the $\mathrm{pH}$ data was performed using the software Statphac II/pharma, Version January 2nd, 1990 (Synectics). 
Electrodes and recorders were calibrated in vitro at $22^{\circ} \mathrm{C}$ using commercial buffer solutions of $\mathrm{pH} 1.07$ and $\mathrm{pH} 7.01$ (Synectics). After calibration, the electrode was passed transnasally and positioned in the body of the stomach, $60 \mathrm{~cm}$ from the nostril. After five minutes $\mathrm{pH}$ was measured. If $\mathrm{pH}$ was less than 6.0 for at least five minutes the position was accepted. If $\mathrm{pH}$ was more then 6.0 radioscopy was performed to check the position of the electrode. The distance of the electrode position from the nares was recorded for each subject at the first experiment and kept constant on all test-days.

During the test days the subjects were ambulatory throughout the whole $\mathrm{pH}$ recording and could follow their normal pattern of life. However, meals and drinks were standardised and provided for during the 24-hour period. Smoking and resting periods were recorded on diary cards by the study subjects.

The daytime period was defined as the period between 9 a.m. and midnight, the nighttime period as the period between midnight and 6 a.m.

\section{Statistical evaluation}

Bacteriological data were given as mean values. Statistical analysis on these data was performed using MANOVA (univariant approach) with Tuckey's correction for the six multiple comparisons.

The $\mathrm{pH}$ data, and the concentrations of nitrate, nitrite and NOC in the gastric juice are given as median values. Statistical analysis on these data was performed using the Friedman test and the Wilcoxon signed rank test; Bonforroni-Holm corrected $\mathrm{p}$-values were presented.

Spearman correlations were calculated between bacteriological and $\mathrm{pH}$ data, bètween nitrite and $\mathrm{pH}$ data, between NOCs and $\mathrm{pH}$ data, between bacteriological and nitrite data, between bacteriological data and NOCs, and between nitrite and NOCs.

Two sided P-values $<0.05$ were assumed to indicate statistical significance.

\section{Ethical considerations}

The study was approved by the Ethics Committee of the Academic Hospital Maastricht, and written informed consent was obtained from each subject before entering the study. 


\section{Results}

All eleven volunteers tolerated the experiments well, and no adverse reaction was reported. Gastric juice samples were available on all 44 test occasions, but from two samples the results of the $\mathrm{N}$-nitroso compound concentration were not available for technical reasons.

\section{pH data}

The group median values with the interquartile ranges (IQ) of the individual median intragastric 24-hour $\mathrm{pH}$ values, the night-time and the daytime during the four different treatment regimens are given in Table IV. 1.

Table IV.1: Median pH values and interquartile ranges for the 24-hour period, nightime, and daytime period, respectively. ( $P$ values indicate overall significancy with Manova. For the differences between warious treatments: see RESULTS)

\begin{tabular}{llllll}
\hline & Placebo & $\begin{array}{c}\text { Ranitidine } \\
\mathbf{3 0 0} \mathbf{~ m g ~ b i d ~}\end{array}$ & $\begin{array}{c}\text { Omeprazole } \\
\mathbf{2 0} \mathbf{~ m g ~ o m ~}\end{array}$ & $\begin{array}{c}\text { Omeprazole } \\
\mathbf{4 0} \mathbf{~ m g ~ o m ~}\end{array}$ & P \\
\hline pH 24 hrs & $1.7(0.9-4.2)$ & $3.7(1.9-6.8)$ & $4.5(1.4-7.6)$ & $5.5(2.1-7.1)$ & $<0.01$ \\
pH 9-24 hr & $1.7(0.9-5.6)$ & $3.2(1.9-6.8)$ & $5.1(1.3-8.8)$ & $6.0(2.3-7.2)$ & $<0.001$ \\
pH 0-6 hr & $1.7(0.9-5.6)$ & $3.9(1.2-8.5)$ & $4.9(1.4-8.7)$ & $4.5(1.6-7.7)$ & $<0.01$ \\
\hline
\end{tabular}

The decrease in 24-hour intragastric acidity after all three drug treatments was significant compared with placebo. No statistically significant difference was found in the decrease in 24-hour intragastric acidity between $300 \mathrm{mg}$ ranitidine b.d. and $20 \mathrm{mg}$ omeprazole, and between the two doses of omeprazole. However, $40 \mathrm{mg}$ omeprazole reduced acidity more than $300 \mathrm{mg}$ ranitidine b.d.

\section{Bacteriological data}

In Table IV.2 the results are given concerning the throat swabs (semiquantitatively) and the bacterial concentrations in the gastric juice. The latter were subdivided into: total bacteria; Gram positive bacteria; Gram negative bacteria; bacterial flora similar to that in the throat; and bacteria not identified in the throat.

For the throat swab we found no statistically significant difference between the various treatments. 
Table VI.2: Mean values and standard deviation (SD) for the bacterial concentrations in the throat stub (semiquartitutively), and the gagicic juice (quantitatively) as log of colony forming units (cfu)/ml. ( $P$ values indicate overal significancy with MANOVA. For the differences between vartous treatments: see RESULTS)

\begin{tabular}{|c|c|c|c|c|c|}
\hline & Placebo & $\begin{array}{l}\text { Ranitidine } \\
300 \mathrm{mg} \text { bid }\end{array}$ & $\begin{array}{c}\text { Omeprazole } \\
20 \mathrm{mg} \text { om }\end{array}$ & $\begin{array}{c}\text { Oneprazole } \\
40 \mathrm{mg} \text { om }\end{array}$ & $\mathbf{P}$ \\
\hline $\begin{array}{l}\text { Throat } \\
\text { swab }\end{array}$ & $\begin{array}{c}2.9 \\
(0.3)\end{array}$ & $\begin{array}{l}3.0 \\
(0.0)\end{array}$ & $\begin{array}{c}2.6 \\
(0.9)\end{array}$ & $\begin{array}{c}3.0 \\
(0.0)\end{array}$ & NS \\
\hline \multicolumn{6}{|c|}{ GASTRIC JUICE } \\
\hline $\begin{array}{l}\text { Total } \\
\text { Bact. }\end{array}$ & $\begin{array}{c}2.5 \\
(2.3)\end{array}$ & $\begin{array}{l}4.9 \\
(1.1)\end{array}$ & $\begin{array}{c}5.2 \\
(2.3)\end{array}$ & $\begin{array}{l}4.7 \\
(2.5)\end{array}$ & $<0.05$ \\
\hline $\begin{array}{c}\text { Gram pos. } \\
\text { Bact. }\end{array}$ & $\begin{array}{c}1.9 \\
(2.4)\end{array}$ & $\begin{array}{l}4.5 \\
(1.7)\end{array}$ & $\begin{array}{l}4.9 \\
(2.6)\end{array}$ & $\begin{array}{c}4.7 \\
(3.1)\end{array}$ & $<0.05$ \\
\hline $\begin{array}{c}\text { Gram neg. } \\
\text { Bact. }\end{array}$ & $\begin{array}{c}1.5 \\
(2.3)\end{array}$ & $\begin{array}{c}3.5 \\
(2.1)\end{array}$ & $\begin{array}{l}3.6 \\
(2.5)\end{array}$ & $\begin{array}{c}3.4 \\
(2.6)\end{array}$ & $<0.05$ \\
\hline $\begin{array}{l}\text { "Throat" } \\
\text { Bact. }\end{array}$ & $\begin{array}{c}2.1 \\
(2.6)\end{array}$ & $\begin{array}{l}4.9 \\
(1.1)\end{array}$ & $\begin{array}{l}5.0 \\
(2.6)\end{array}$ & $\begin{array}{l}4.7 \\
(3.3)\end{array}$ & $<0.05$ \\
\hline $\begin{array}{c}\text { "Non Throat" } \\
\text { Bact. }\end{array}$ & $\begin{array}{c}1.5 \\
(11.4)\end{array}$ & $\begin{array}{c}1.9 \\
(1.4)\end{array}$ & $\begin{array}{l}2.1 \\
(1.6)\end{array}$ & $\begin{array}{c}1.7 \\
(1.4)\end{array}$ & NS \\
\hline
\end{tabular}

After all forms of acid inhibition, a significant and similar increase of the total bacteria, Gram positive bacteria, Gram negative bacteria, and the bacterial flora emanating from the throat was found in the gastric juice. Regarding the small fraction of bacteria not emanating from the throat no significant difference was found between placebo and the various treatments.

In Table IV. 3 the bacterial species cultured, with their maximum concentrations, and the number of subjects with positive cultures on the different treatments are given. 
Table IV.3: The bacterial species, with their maximum concentrations (log cfu/nil) and the numbers of subjects with positive cultures after the different treatments. (Throat-bacteria are not included in this table).

\begin{tabular}{|c|c|c|c|}
\hline PLACEBO & $\begin{array}{l}\text { RANITIDINE } \\
300 \mathrm{mg} \text { bid }\end{array}$ & $\begin{array}{l}\text { OMEPRAZOLE } \\
20 \mathrm{mg} \text { om }\end{array}$ & $\begin{array}{l}\text { OMEPRAZOLE } \\
40 \mathrm{mg} \text { om }\end{array}$ \\
\hline \multirow[t]{3}{*}{$\begin{array}{l}\text { Staph. aureus }(4.0) \\
\text { in } 4 \text { subjects }\end{array}$} & $\begin{array}{l}\text { Staph. aureus }(5.0) \\
\text { in } 5 \text { subjects }\end{array}$ & $\begin{array}{l}\text { Staph. aureus ( } 4.0) \\
\text { in } 7 \text { subjects }\end{array}$ & $\begin{array}{l}\text { Staph. aureus ( } 5.0) \\
\text { in } 6 \text { subjects }\end{array}$ \\
\hline & $\begin{array}{l}\text { Staph. epidermidis }(6.0) \\
\text { in } 2 \text { subjects }\end{array}$ & & $\begin{array}{l}\text { Staph. epidermidis }(3.0) \\
\text { in } 1 \text { subject }\end{array}$ \\
\hline & $\begin{array}{l}\text { Streptococci spp }(3.0) \\
\text { in } 1 \text { subject }\end{array}$ & & \\
\hline \multirow{3}{*}{$\begin{array}{l}\text { Einterobacter }(1.0) \\
\text { in } 1 \text { subject } \\
\text { Bacteroides }(3.0) \\
\text { in } 1 \text { subject }\end{array}$} & $\begin{array}{l}\text { Enterobacter (1.3) } \\
\text { in } 1 \text { subject }\end{array}$ & $\begin{array}{l}\text { Enterobacter }(2.0) \\
\text { in } 1 \text { subject }\end{array}$ & $\begin{array}{l}\text { Enterobacter }(2.0) \\
\text { in } \mathbb{1} \text { subject }\end{array}$ \\
\hline & & & \\
\hline & & $\begin{array}{l}\text { Pseudomonas ( } 3.0) \\
\text { in } 1 \text { subject: }\end{array}$ & $\begin{array}{l}\text { Pseudomonas }(2.0) \\
\text { in } 11 \text { subject }\end{array}$ \\
\hline $\begin{array}{l}\text { Candida ( } 3.0) \\
\text { in } 4 \text { subjects }\end{array}$ & $\begin{array}{l}\text { Candida (3.0) } \\
\text { in } 5 \text { subjects }\end{array}$ & $\begin{array}{l}\text { Candida (3.0) } \\
\text { in } 6 \text { subjects }\end{array}$ & $\begin{array}{l}\text { Candida ( } 3.7) \\
\text { in } 5 \text { subjects }\end{array}$ \\
\hline
\end{tabular}

\section{Nitrate, nitrite and $\mathbf{N}$-nitroso compounds (NOC)}

Table IV.4 shows the results of the intragastric concentrations of nitrate, nitrite and NOC. There were no significant differences between the various treatments for any of these.

Table IV.4: Median values and interquartile ranges for nitrate, nitrite and $\mathrm{N}$-nitroso compounds (NOC) in the gastric juice. (P values indicate overall significancy with MANOVA)

\begin{tabular}{cccccc}
\hline & Placebo & $\begin{array}{c}\text { Ranitidine } \\
\mathbf{3 0 0} \mathbf{~ m g} \text { bid }\end{array}$ & $\begin{array}{c}\text { Omeprazole } \\
\mathbf{2 0} \mathbf{~ m g ~ o m ~}\end{array}$ & $\begin{array}{c}\text { Omeprazole } \\
\mathbf{4 0} \mathbf{~ m g ~ o m ~}\end{array}$ & p \\
\hline Nitrate & 396 & 400 & 370 & 410 & NS \\
$\mu$ mol/l & $(280-1100)$ & $(160-2200)$ & $(59-2013)$ & $(200-1200)$ & \\
Nitrite & 13.2 & 24.0 & 22.1 & 9.8 & NS \\
$\mu$ mol/l & $(4.6-62)$ & $(9.0-220)$ & $(4.9-64)$ & $(4.6-360)$ & \\
NOC & 1.95 & 2.22 & 1.36 & 0.54 & NS \\
$\mu$ mol/l & $(0.08-24)$ & $(0.08-25.2)$ & $(0.16-4.5)$ & $(0.08-5.4)$ & \\
\hline
\end{tabular}


Correlations between intragastric acidity and gastric juice concentrations of bacteria, nitrite and $\mathrm{N}$-nitroso compounds

As Figure IV.1 shows, a positive correlation was found between the Gram positive bacteria and the median 24-hour $\mathrm{pH}(\mathrm{P}<0.05)$. This was also present for the daytime period $(\mathrm{P}=0.01)$ and the night-time period $(\mathrm{P}=0.05)$ separately. A positive correlation was also found between the Gram negative bacteria and the daytime period $(\mathrm{P}<0.05)$ (Figure IV.2); however, no correlation was found between the Gram negative bacteria and the night-time period and the median 24-hour $\mathrm{pH}$. For the total intragastric bacteria a positive correlation was only found between the bacterial concentration and the daytime period $(\mathrm{P}<0.05)$ (Figure IV.3), but not for the night-time period and the total 24 hours.

Intragastric nitrite concentrations were neither correlated with the total 24 -hour $\mathrm{pH}$, nor with the daytime and the night-time $\mathrm{pH}$ values, separately.

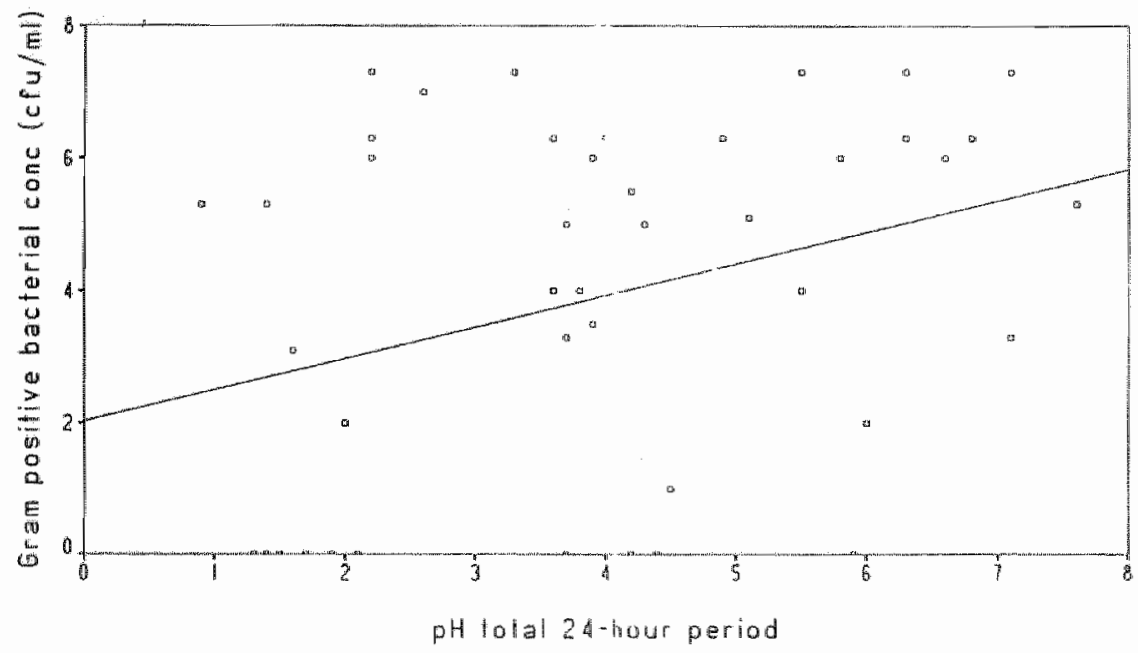

Figure IV.1: Correlation between Gram positive bacterial concentrations and median $\mathrm{pH}$ during the notal 24-hour period ( $\mathrm{P}<0.05)$ 


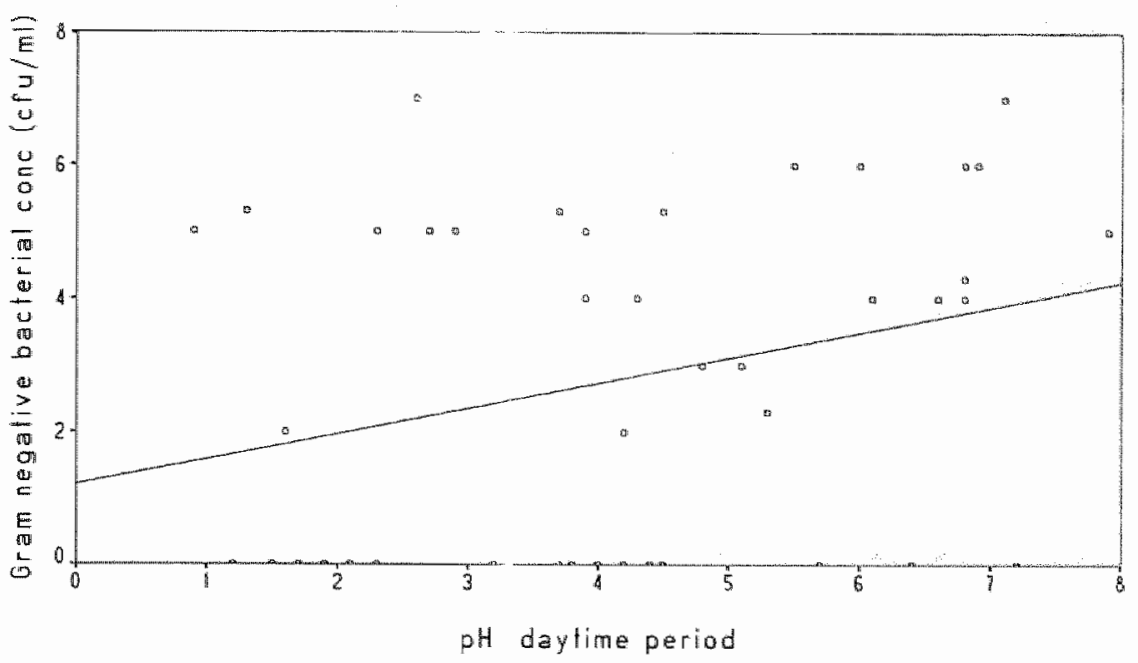

Figure IV.2: Correlation between Gram negative bacterial concentrations and median $\mathrm{pH}$ during the daytime period $(\mathbf{P}<0.05)$

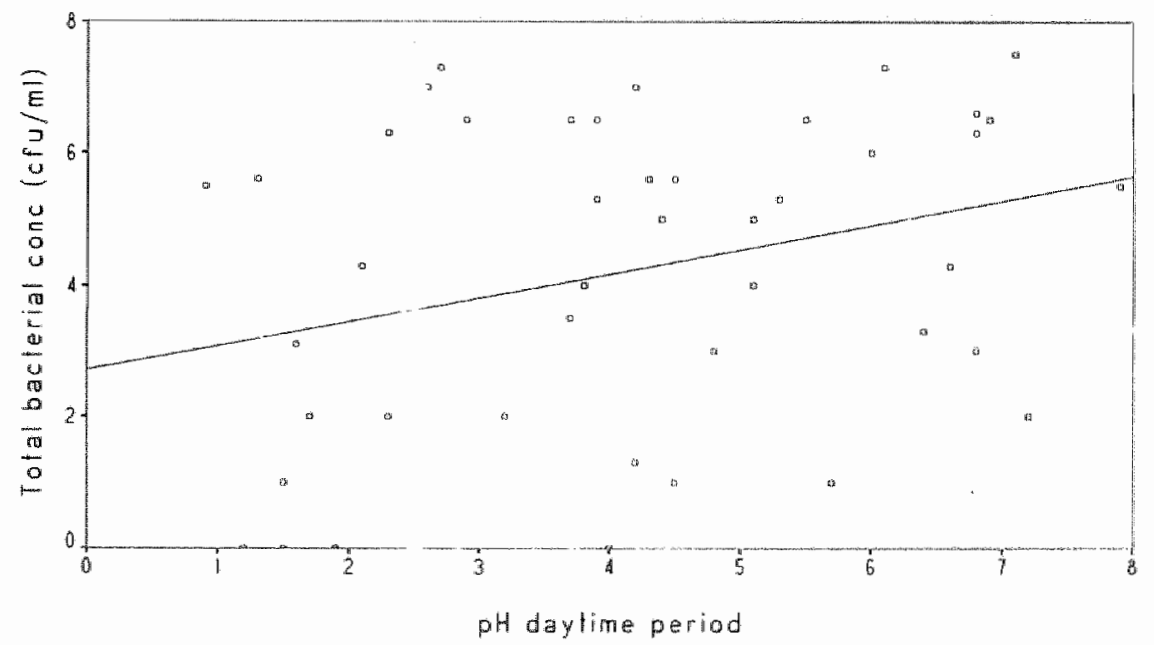

Figure IV.3: Correlation between total bacterial concentrations and median pH during the daytime period $(\mathrm{P}<0.05)$ 
However, a positive correlation was found between the intragastric nitrite concentrations and each of the following: Gram positive bacterial concentration $(P<0.001)$, Gram negative bacterial concentration $(P<0.001)$, and total bacterial concentration $(\mathrm{P}=0.001$ ) (Figure IV $4 \mathrm{a}-\mathrm{c}$ ).

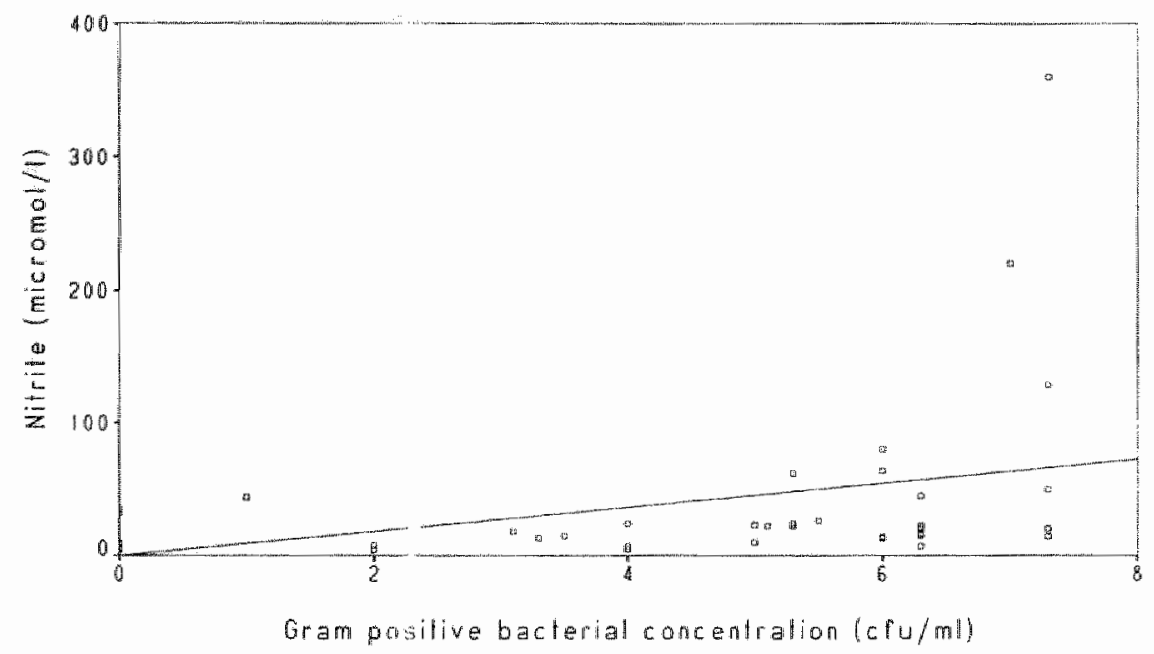

Figure IV.4a: Correlation between Gram positive bacterial concentrations and intragastric nitrite concentrations $(\mathrm{P}<0.001)$

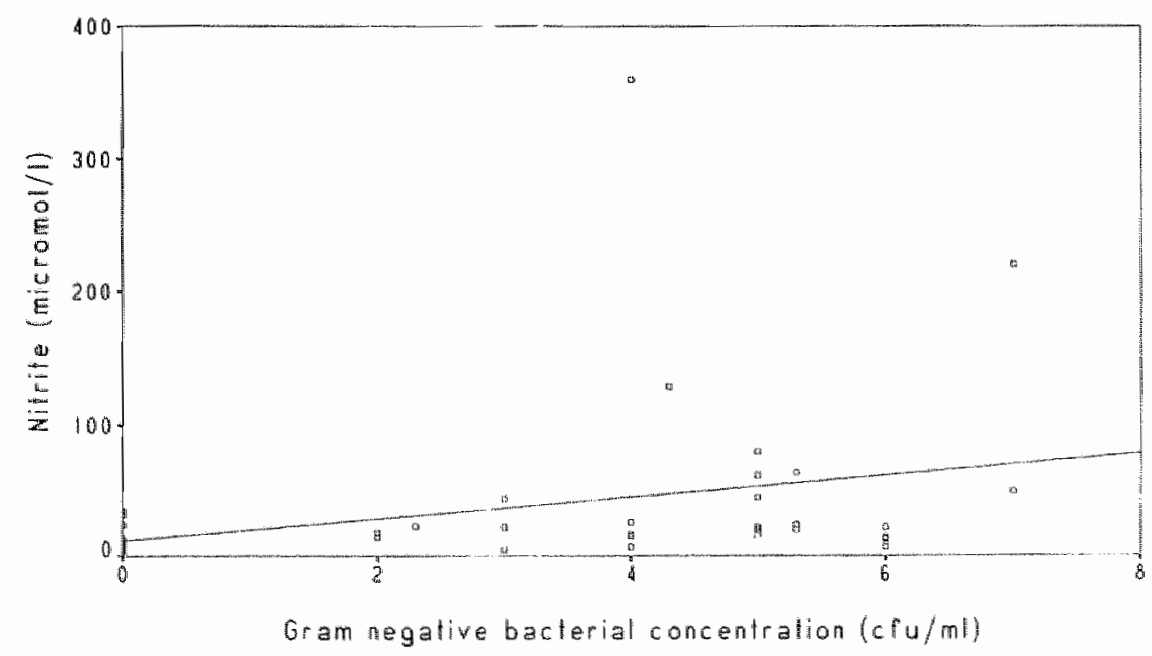

Figure IV.4b: Correlation between Gram negative bacterial concentrations and intragastric mitrite concentrations $(\mathrm{P}<0.001)$ 


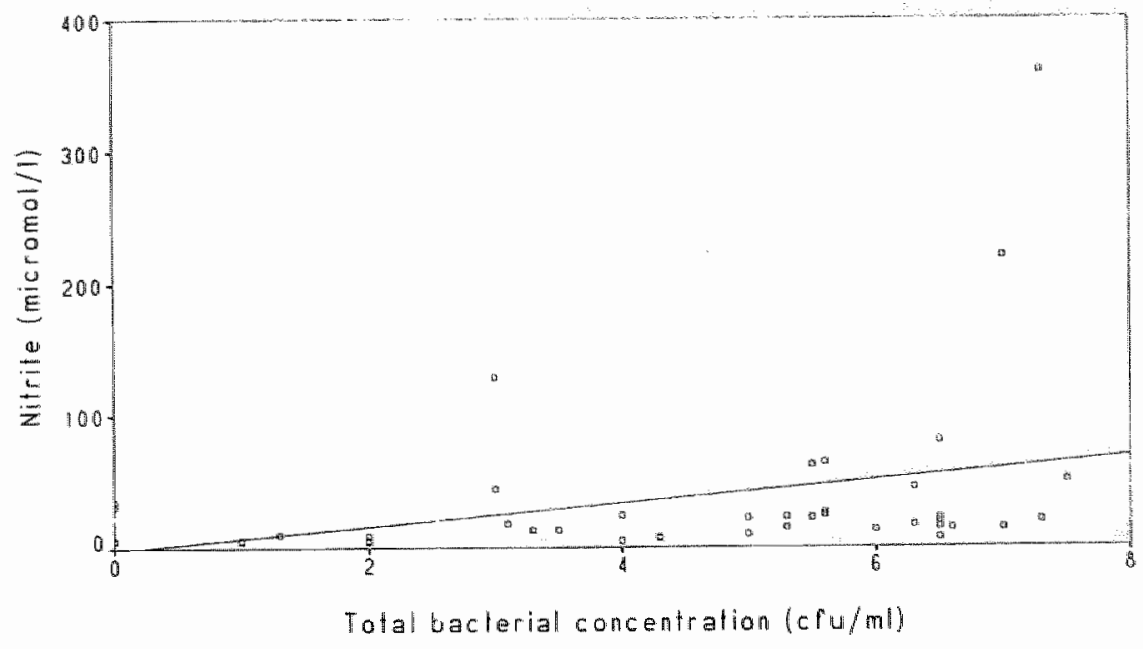

Figure IV.4c: Correlation between total bacterial concentrations and intragastric nitrite concentrations $(\mathrm{P}<0.001)$

In Figure IV.5a and $\mathrm{b}$ weak negative correlations are found between the intragastric NOC concentrations and the daytime $\mathrm{pH}(\mathrm{P}<0.05)$ and the median 24-hour $\mathrm{pH}$ $(\mathrm{P}=0.05)$ separately. There was no significant correlation shown between the NCO concentrations and the median night-time intragastric $\mathrm{pH}$.

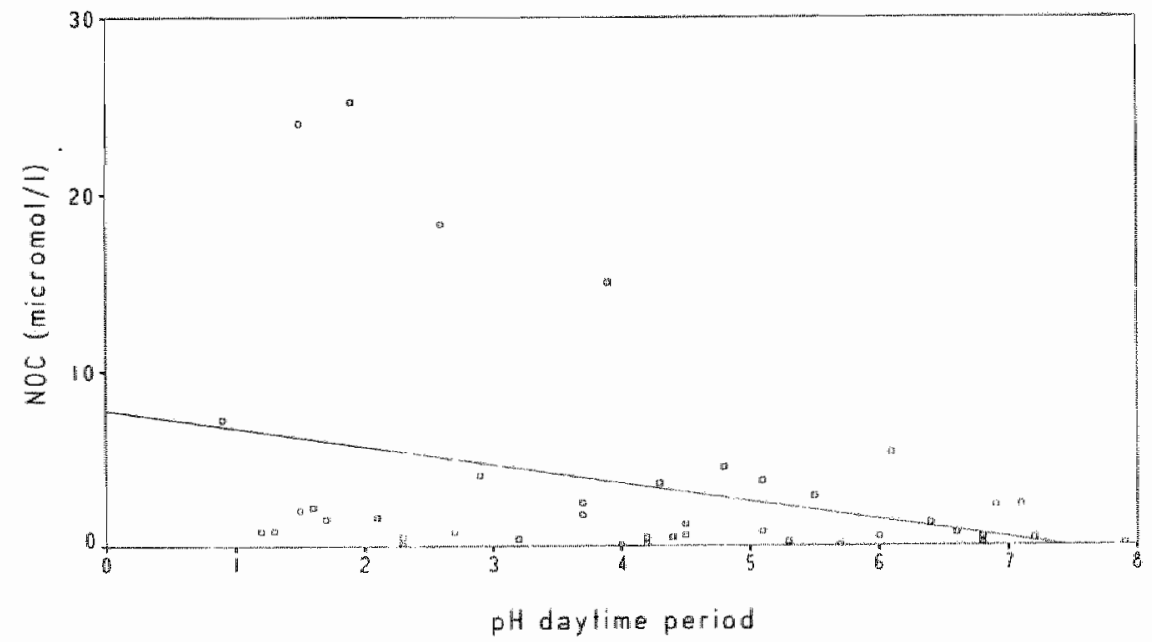

Fugure IV.5a: Negative correlation between intragastric $\mathbb{N}$-nitroso compounds and median pH during daytime period $(\mathrm{P}<0.05)$ 


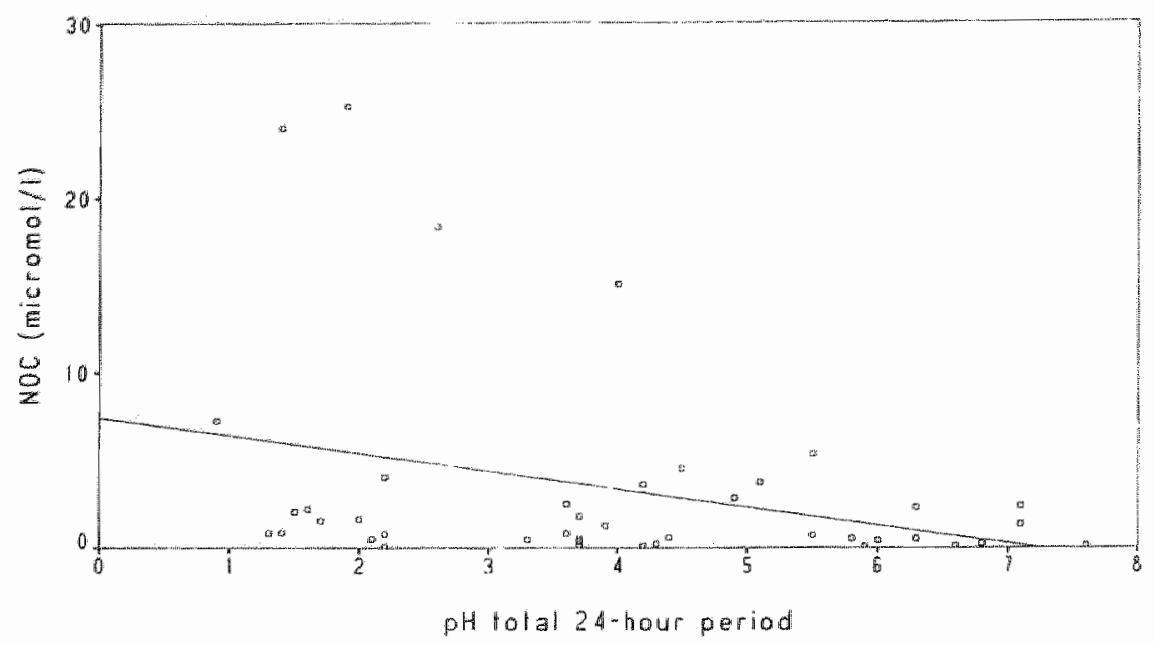

Figure IV.5b: Negative correlation between intragastric $\mathrm{N}$-nitroso compounds and median $\mathrm{pH}$ during the total 24 -hour period $(\mathrm{P}<0.05)$

No correlation was found between the NOC concentrations and the Gram positive bacterial concentrations, the Gram negative bacterial concentrations, and the total bacterial concentrations.

In Figure IV.6 the positive correlation between intragastric nitrites and NOC concentrations is shown $(\mathrm{P}<0.005)$.

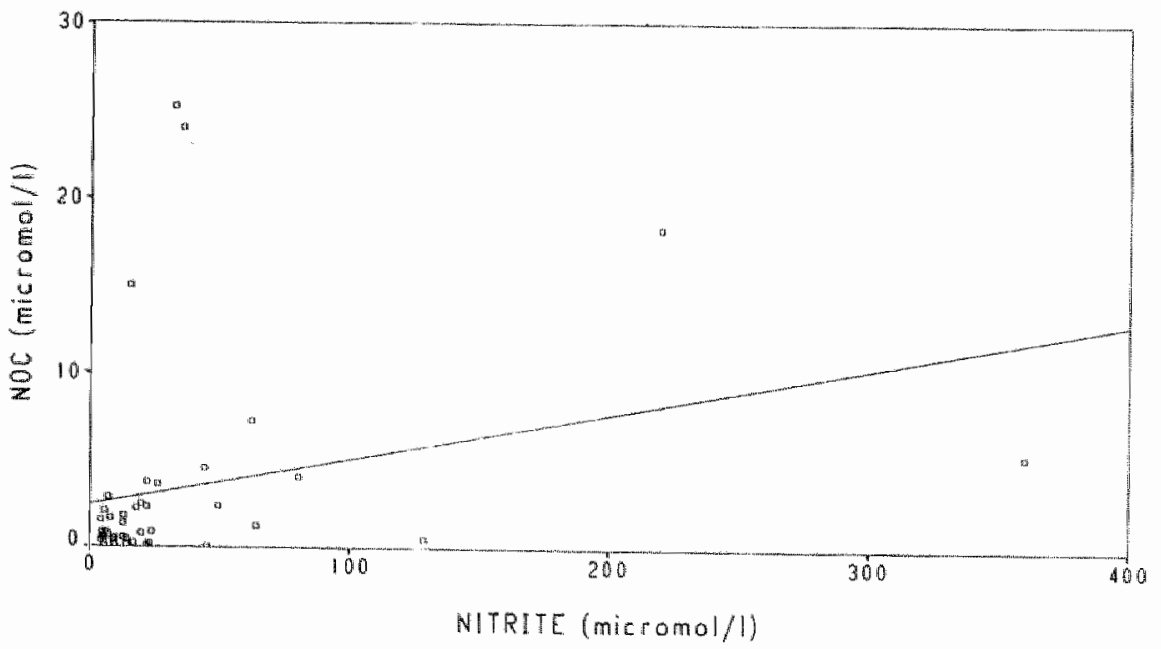

Figure IV.6: Correlation between intragastric $\mathrm{N}$-nitroso compounds and intragastric nitrite concentrations $(\mathbb{P}<0.005)$ 


\section{Discussion}

There is little doubt that intragastric formation of nitrites and $\mathrm{N}$-nitroso compounds is involved in gastric carcinogenesis and that these events are a consequence of intragastric bacterial colonisation due to reduced acid secretion in atrophic gastritis $^{22-27}$. There has been much debate, however, concerning the role of druginduced gastric hyposecretion in this respect as some groups could indicate increases of intragastric nitrite and NOC after antacids ${ }^{11,12}$ or H2RAs ${ }^{19,28-31}$, whereas others could not ${ }^{32}$. Omeprazole, as the first representative of the proton pump inhibitors, has been reported to cause bacterial overgrowth and formation of nitrite and NOC in healthy volunteers ${ }^{15}$, but only to a minor degree in patients with peptic disease $^{33}$. It was the aim of this study to elucidate the mechanisms of intragastric nitrite and NOC formation following various modes of medical gastric acid inhibition.

As previously reported in detail ${ }^{34}$, the three drug-treatment schedules applied in this study exerted a gradually increasing reduction of intragastric acidity. It was interesting to observe that the intragastric bacterial overgrowth resulting from this artificial hypochlorhydria - mainly consisting of Gram positive bacteria - was similar following all three drug regimens. It can be hypothesized that the moderate elevation of the median 24-hour pH exerted by $300 \mathrm{mg}$ ranitidine b.d. has already surpassed the threshold which is necessary for intragastric bacterial colonization to take place. Short-term stronger acid inhibition by $40 \mathrm{mg}$ omeprazole o.m. does not lead to further bacterial proliferation. This finding confirms previous reports in which intragastric bacterial overgrowth was reported already after therapeutic doses of H2RAs ${ }^{9.11 .13 .14}$, and others in which intragastric bacterial concentrations after 30 $\mathrm{mg}$ omeprazole $0 . \mathrm{m}$. were in the same range of magnitude ${ }^{15}$.

In this study it also became evident that intragastric bacterial overgrowth was mainly correlated to the hypochlorhydria present during the daytime period. This may indicate that bacteria cultured from fasting gastric juice are not just a consequence of nightly acid inhibition, disappearing after any incidental drop of intragastric $\mathrm{pH}$ in the subsequent daytime period, but represent a resident flora with some adherence to the gastric mucosa ${ }^{35}$.

Ruddell et al. have shown that many bacterial species are capable of reducing nitrate to nitrite ${ }^{36}$. In this study no further attempt was made to identify the proportion of nitrate-reducing bacteria, as this has already been done by others and by ourselves ${ }^{14,16,37,38}$. However, it could be demonstrated that intragastric nitrate- 
reduction was related to both Gram positive and Gram negative bacteria. In further studies on this subject it may therefore be sufficient to quantitate total intragastric bacterial flora without further subtyping.

Only on a few occasions were the intragastric nitrite concentrations reached after the three drug treatments elevated above the interquartile ranges of placebo treatment. However, in a few instances very high fasting intragastric nitrite concentrations were measured.

Assessment of intragastric NOCs has been a subject of much methodological and pathophysiological dispute. This discussion has recently been further advanced by the findings of Xu and Reed ${ }^{39,40}$, suggesting that only "bedside" analysis of gastric juice without addition of sulphamic acid would result in reliable results. The method used in our study is identical with the method described by Pignatelli et al ${ }^{21}$ and has been applied in a considerable number of studies in which increases of intragastric NOC due to acid inhibition and bacterial overgrowth could be demonstrated ${ }^{16,41}$. The method estimates mainly stable or non-volatile NOC. As the non-volatile NOC are a composite group of short-lived substances with fast and rather impredictable metabolization, any determination in human material will be little more than the documentation of a fugitive event. However, even if the method applied in this study might not be optimal in a biological and analytical sense, it will probably not overestimate the formation of NOC. Due to the controlled design of the study it will most probably correlate the NOC concentrations with the other changes of the intragastric milieu caused by the various forms of acid inhibition.

The event most closely correlated to the rise of intragastric NOOC concentration was the nitrite concentration of the gastric juice, rather than the concentration of intragastric bacteria itself. Nitrite formation - either bacterial or chemical - seems to be the determining factor for the NOC formation. Therefore, if in future studies the consequences of NOC formation during long-lasting hypochlorhydria or achlorhydria should be assessed, monitoring of intragastric nitrites seems to be an acceptable proxy for the cumbersome and expensive measurement of NOC concentrations.

It has been the subject of much discussion whether intragastric nitrosation of amines can only take place in an acidic milieu or whether it also can occur at the elevated $\mathrm{pH}$ levels that are favourable for bacterial proliferation and nitrate formation $^{42,43}$. Xu and Reed have indicated that this chemical reaction has two preferential $\mathrm{pH}$ areas, namely between $\mathrm{pH} 2$ to 3 and above $6^{40}$. This was recently 
corroborated by own studies regarding the formation of volatile intragastric $\mathrm{NOC}^{44}$. In the present study the inverse correlation of 24-hour $\mathrm{pH}$-values with the fasting intragastric NOC concentrations indicates that $\mathrm{N}$-nitrosation of amines can occur at all levels of intragastric acidity but has a preference for the acidic $\mathrm{pH}$ area in which this process is mainly biochemically and not bacterially induced.

In summary, already short-term moderate as profound medical inhibition of gastric acid secretion results in overgrowth of mainly Gram positive bacteria. This leads in a few cases to a significant reduction of intragastric nitrate to nitrite. Nitrite formation is then the limiting factor for the formation of $\mathrm{N}$-nitroso compounds, a reaction which tends to take place more easily at lower than at higher intragastric $\mathrm{pH}$-levels. In order to assess the risk between long-lasting gastric acid inhibition and gastric malignancy, monitoring of intragastric nitrite concentrations seems to be an adequate and relatively convenient alternative to estimations of intragastric NOC concentrations. 


\section{References}

1 Sharma BK, Walt RP, Pounder RE et all. Optimal dose of oral omeprazole for maximal 24 hour decrease of intra-gastric acidity. Gut 1984;25:957-964.

2 Chiverton SG, Howden CW, Burget DW, Hunt RH. Omeprazole (20 mg) daily given in the morning or evening: a comparison of effects on gastric acidity, and plasma gastrin and omeprazole concentration. Aliment Pharmacol Therap 1992;6:103-111.

3 Patel $\mathbb{N}$, Ward UM, Brown $A K$ et al. The effect of ranitidine $300 \mathrm{mg}$ at night, ranitidine $300 \mathrm{mg}$ twice dally and placebo on 24 -h intragastric $\mathrm{pH}$ and 24 -h plasma gastrin in healthy subjects. Eur J Gastroenterol Hepatol 1993;5:161-164.

4 Hunt RH. The protective role of gastric acid. Scand J Gastroenterol 1988;23 (Suppl. 146):34-39.

5 Gianella RA, Broitman SA, Zamchek N. Gastric acid barrier to ingested microorganisms in man: studies in vivo and in vitro. Gut 1972;13:251-256.

6 Cook GC. Infective gastroenteritis and its relationship to reduced gastric acidity. Scand J Gastroenterol 1985;20 (Suppl 111):17-22.

7 Howden CW, Hunt RH. Relationship between gastric secretion and infection (progress report). Gut 1987;28:96-107.

8 Husebye E, Skar V, Hoverstad T, Melby K. Fasting hypochlorhydria with Gram positive flora is highly prevalent in healthy old people. Gut 1992;33:1331-1337.

9 Meyerick Thomas J, Misiewicz JJ, Cook et al. Effects of one year's treatment with ranitidine and of truncal vagotomy on gastric contents. Gut 1987;28:726-738.

10 Enander LK, Nilsson F, Ryden AC, Schwan A. The aerobic and anaerobic microflora of the gastric remnant more than 15 years after Billroth II resection. Scand $J$ Gastroenterol 1982;17:715-720.

11 Snepar R, Proporad GA, Romano R et al. Effect of cimetidine and antacid on gastric microbial flora. Infect Immun 1982;36:518-524.

12 Du Moulin GC, Paterson DG, Hedley-Whyte $J$, Lisbon $J$. Aspiration of gastric bacteria in antacid-treated patients:" a frequent cause of postoperative colonisation of the airway. Lancet $1982 ; \mathrm{i}: 242-245$.

13 Milton-Thompson GJ, Lightfoot NF, Ahmet Z et al. Intragastric acidity, bacteria, nitrite, and $\mathrm{N}$-nitroso compounds before, during and after cimetidine treatment. Lancet $1982 ;$ i: $1091-1095$.

14 Stockbrügger RW, Cotton PB, Eugenides $\mathrm{N}$ et al. Intragastric nitrites, nitrosamines, and bacterial overgrowth during cimetidine treatment. Gut 1982;23:1048-1054.

15 Sharma BK, Santana IA, Wood EC et al. Intragastric bacterial activity and nitrosation before, during and after treatment with omeprazole. BMJ 1984;289:717-719.

16 Verdu E, Viani F, Armstrong D et al. Effects of omeprazole on intragastric bacterial counts, nitrates, nitrites, and N-nitroso compounds. Gut 1994;35:445-460.

17 Hall CN, Darkin D, Brimblecombe R et al. Evaluation of the nitrosamine hypothesis of gastric carcinogenesis in precancerous conditions. Gut 1986;27:491-498. 
18 Northfield TC, Hall CN. Carcinoma of the gastric stump: risks and pathogenesis. Gut $1990 ; 31: 1217-1219$.

19 Reed $P_{3}$ Smith $P_{*}$ Haines $\mathrm{K}$ et al. Effect of cimetidine on gastric juice $\mathrm{N}$-nitrosamine concentration. Lancet $1981 ;$ ii:553-556.

20 Green $L$, Wagner $D$, Glogowski $J$ et al. Analysis of nitrate, nitrite and $\llbracket 15 N]$ nitrate in biological fluids. Anal Biochem 1982;126:131-138.

21 Pignatelli B, Richard I, Bouragrade M, Bartch H. Improved group determination of total $\mathbb{N}$-nitroso compounds in human gastric juice by chemical denitrosation and thermal energy analysis. Analyst 1987;112:945-949.

22 Tannenbaum SR. N-nitroso compounds: a perspective on human exposure. Lancet $1981 ; \mathrm{ii}: 629-631$.

23 Lijinsky W. Nitrosamines and nitrosamides in the aetiology of gastrointestinal cancer. Cancer $1977 ; 40: 2446-2449$.

24 Reed $P_{*}$ Smith $\mathrm{P}$, Haines $\mathrm{K}$ et al. Gastric juice $\mathrm{N}$-nitrosamines in health and gastroduodenal disease. Lancet 1981 ;ii:550-552.

25 Ruddell W, Bone $\mathrm{E}$, Hill $\mathrm{M}$ et al. Gastric juice nitrate: a risk factor for cancer in the hypochlorhydric stomach ? Lancet 1976; ii: 1037-1039.

26 Jones S, Davies P, Savage A. Gastric-juice nitrite and gastric cancer. Lancet $1987 ; \mathrm{i}: 1355$.

27 Hall C, Cook A, Darkin D et al. Evaluation of the nitrosamine hypothesis of gastric carcinogenesis in man. Clin Sci 1984;66:34P-35P.

28 Hamilton $\mathbb{I}$, Wormsley $\mathrm{BW}, \mathrm{O}^{\prime}$ Connor HJ, Axon A. Effects of tripotassium dicitrato bismuthate (TDB) tablets or cimitidine in the treatment of duodenal ulcer. Gut $1983 ; 24: 1148-1151$.

29 Hillman KM, Riorden T, O'Farrell SM, Tabaqchali S. Colonization of the gastric contents in critically ill patients. Crit Care Med 1982;10:444-447.

30 Garvey BM, Mc Cambley JA, Tuxen DV. Effects of gastric alkalization on bacterial colonization in critically ill patients. Crit Care Med 1989;17:211-216.

31. Reusser $P$, Scheidegger D, Buser $M$ et al. Role of gastric colonization in nosocomial infections and endotoxemia: a prospective study in neurosurgical patients on mechanical ventilation. IInfect Dis 1989;160:414-421.

32 Muscroft T, Youngs DJ, Burden D, Keighley M. Cimetidine is unlikely to increase formation of intragastric $\mathrm{N}$-nitroso compounds in patients taking a normal diet. Lancet $1981 ; i: 408-410$.

33 Fried M, Siegrist $H$, Frei $R$ et al. Duodenal bacterial overgrowth during treatment in outpatients with omeprazole. Gut 1994;35:23-26.

34 Houben G, Hooi J, Hameeteman W, Stockbrugger R. Twenty-four-hour intragastric acidity: $300 \mathrm{mg}$ ranitidine b.d., $20 \mathrm{mg}$ omeprazole $0 . \mathrm{m} ., 40 \mathrm{mg}$ omeprazole $0 . \mathrm{m}$. vs placebo. Aliment Pharmacol Ther 1995;9:649-654.

35 Jonkers D, Stobberingh E, Stockbrugger $R$. Omeprazole inhibits growth of Grampositive and Gram-negative bacteria including Helicobacter pylori in vitro. J. Antimicr Chem Ther 1996;37:145-150. 
36 Ruddell $W$, Axon $A$, Findley $J$ et al. The effect of cimetidine on the gastric bacterial microflora. Lancet $1980 ; 1: 672-674$.

37 Stockbrugger RW. Bacterial overgrowth as a consequence of reduced gastric acidity. Scand J Gastroenterol 1985; Suppl.111:7-16.

38 Thomas I, Misiewicz J Cook A et al. Effect of one year's treatment with ranitidine and of truncal vagotomy on gastric contents. Gut $1987 ; 28: 726-738$.

39 Xu GP, Reed PI. Instability of N-nitroso compounds in gastric juice and preliminary results from analysis of fresh samples by using an improved analytical method. Eur $J$ Cancer Prev 1.993;2:381-386.

$40 \mathrm{Xu}$ GP, Reed PI. N-nitroso compounds in fresh gastric juice and their relation to intragastric $\mathrm{pH}$ and nitrite employing an improved analytical method. Carcinogenesis $1993 ; 14: 2547-2551$.

41 Pignatelli $\mathbb{B}$, Malaveille $\mathrm{C}$, Rogatka $\mathrm{A}$. et al. Mutagens, $\mathrm{N}$-mitroso compounds and their precursors in gastric juice from patients with and without precancerous lesions of the stomach. Eur J Cancer 1993;29A:2031-2039.

42. Calmels $S$, Oshima $H$, Vincent $P$ et al. Screening of microorganisms for nitrosation catalysis at pH 7 and kinetic studies on nitrosamine formation from secondary amines by E. Coli strains. Carcinogenesis 1985;6:911-915.

43 Leach $S$, Thompson $M$, Hill $M$. Bacterially catalysed $N$-nitrosation in the human stomach. Carcinogenesis 1987;8:1907-1912.

44 Dallinga J, Pachen D, Kleinjans J. Determination of volatile $\mathrm{N}$-nitrosamines in gastric juice and in urine by gas chromatography-mass spectometry. Eur $J$ Cancer Prev 1996;5(Suppl 1):63-66. 


\section{Chapter V}

Twenty-four-hour intragastric pH, basal and meal-stimulated serum gastrin, and serum pepsinogens $\mathrm{A}$ and $\mathrm{C}$ following $300 \mathrm{mg}$ ranitidine b.d., $20 \mathrm{mg}$ omeprazole o.m., $40 \mathrm{mg}$ omeprazole o.m. or placebo

GMP Houben, I Biemond, W Hameeteman, CBHW Lamers, RW Stockbrügger 


\section{Abstract}

Background: Gastric acid inhibition results in an increase of serum gastrin. Gastrin may be involved in the increased release of pepsinogen $\mathrm{A}$ and $\mathrm{C}$ during antisecretory therapy.

Aim: We evaluated the effects of three regimens of medical acid inhibition in a doubleblind, placebo-controlled multiple cross-over study to elucidate the effects of acid inhibition on serum gastrin and serum pepsinogen levels.

Methods: Intragastric 24-hour $\mathrm{pH}$ monitoring was performed, and basal and mealstimulated serum gastrin and serum pepsinogen $A$ and $C$ were measured in 11 healthy subjects. Each subject received for 2 weeks ranitidine $300 \mathrm{mg}$ b.d., $20 \mathrm{mg}$ omeprazole o.m., $40 \mathrm{mg}$ omeprazole o.m., and placebo, respectively.

Results: Ranitidine $300 \mathrm{mg}$ b.d., $20 \mathrm{mg}$ omeprazolle and $40 \mathrm{mg}$ omeprazole all decreased 24-hour gastric acidity significantly when compared to placebo, $40 \mathrm{mg}$ omeprazole significantly more than $300 \mathrm{mg}$ ranitidine b.d. In order of $300 \mathrm{mg}$ ranitidine b.d., $20 \mathrm{mg}$ omeprazole $0 . \mathrm{m}$., $40 \mathrm{mg}$ omeprazole $0 . \mathrm{m}$., each of the treatments produced a significant increase of basal, meal-stimulated and integrated meal-stimulated serum gastrin compared to the previous one and compared to placebo. Serum pepsinogen $A$ and $C$ levels were not increased after ranitidine compared to placebo, but higher after $20 \mathrm{mg}$ omeprazole and 40 mg omeprazole compared with both placebo and ranitidine $(\mathrm{p}<0.001)$, and higher after $40 \mathrm{mg}$ omeprazole than after $20 \mathrm{mg}$ omeprazole. Positive correlations were found between serum gastrin levels and serum pepsinogen $\mathrm{A}$ and $\mathrm{C}$ levels, respectively.

Conclusion: Increasing acid inhibition leads to basal and particularly meal-induced hypergastrinaemia and to hyperpepsinogenaemia, the latter possibly an expression of a proliferative action on the chief cell mass. 


\section{Introduction}

Gastro-oesophageal refluxdisease (GORD), gastric ulcer and duodenal ulcer are acid related diseases. Modern acid inhibitory drugs, such as proton pump inhibitors and histamine-2-receptor antagonists, the latter in high doses, are able to profoundly reduce gastric acid secretion ${ }^{1-3}$.

Profound acid inhibition results in increases in serum gastrin due to interaction in the feedback mechanism between intragastric acidity and antral gastrin release ${ }^{4.5}$. In rats, hypergastrinaemia induced by long-term administration of omeprazole has resulted in enterochromaffinlike-cell (ECL-cell) hyperplasia and, subsequently, gastric carcinoid formation ${ }^{6,7}$. Additional studies have shown that these effects are not restricted to omeprazole therapy but are also found during treatment with other proton pump inhibitors ${ }^{8}$ and high doses $\mathrm{H} 2$-receptor antagonists ${ }^{9-11}$, suggesting that these effects are secondary to long-term profound acid inhibition.

The finding that the effect of omeprazole on the ECL-cells was prevented by antrectomy points to a crucial role for hypergastrinaemia in ECL-cell hyperplasia and carcinoid formation'.

In patients with type A atrophic gastritis or with the Zollinger-Ellison syndrome, hypergastrinaemia is often accompanied by an increased incidence of gastric carcinoids ${ }^{12-16}$. Although carcinoids have not been observed during omeprazole therapy in man, the possibility cannot be excluded that long term pronounced hypergastrinaemia may increase the risk of carcinoid formation.

Human pepsinogen consists of two biochemically and immunologically different isozymogens, pepsinogen $\mathrm{A}$ and pepsinogen $\mathrm{C}$.

Pepsinogen $\mathrm{A}$ is secreted only by the chief-cells in the gastric fundic mucosa ${ }^{17}$, pepsinogen $\mathrm{C}$ by both fundic and antral mucosa and also in the proximal duodenum ${ }^{18}$. It is reported that short-term administration of omeprazole in unoperated subjects increases both pepsinogen $A$ and pepsinogen $C$ levels ${ }^{19-22}$. Long-term maintenance therapy with omeprazole in patients with reflux oesophagitis caused a marked increase in serum pepsinogen $\mathrm{A}$ and pepsinogen $\mathrm{C}$ levels after 3 months of treatment, after which period the serum pepsinogen levels stabilized $^{23}$. It has also been demonstrated that prolonged infusion of pentagastrin stimulates serum pepsinogen A levels ${ }^{24}$. Furthermore hypergastrinaemic duodenal ulcer patients, patients with gastrinoma and with antral G-cell hyperfunction usually have elevated serum pepsinogen level $\mathrm{s}^{25-27}$. These data suggest that gastrin may be involved in the increased release of pepsinogen $\mathrm{A}$ and pepsinogen $\mathrm{C}$ during 
antisecretory therapy.

Optimal inhibition of gastric acid secretion has to defined, providing a maximal healing rate of target lesions, but avoiding side-effects as much as possible. This is particularly important in disorders necessitating long-term treatment such as GORD. Concerning this aspect we evaluated the effects of three different regimens of supposedly strong acid inhibition (300 $\mathrm{mg}$ ranitidine b.d., $20 \mathrm{mg}$ omeprazole o.m., $40 \mathrm{mg}$ omeprazole o.m.) compared to placebo by means of ambulant 24-hour intragastric $\mathrm{pH}$ monitoring and measurements of basal and meal stimulated serum gastrin and basal serum pepsinogen $\mathrm{A}$ and pepsinogen $\mathrm{C}$ levels. To our knowledge, a direct comparison of these three commonly used drug regimens under this aspect has not been published so far.

\section{Subjects and methods}

This study was a randomized, double-blind, 4-way cross-over, single center study in 11 healthy volunteers ( 7 females, 4 males; age $20-41$ years). Each subject received four drug regimens in a random order, $300 \mathrm{mg}$ ranitidine b.d., $20 \mathrm{mg}$ omeprazole o.m., $40 \mathrm{mg}$ omeprazole o.m., and placebo. Each regimen was given for two weeks. Wash-out periods of 2 weeks between the dosing regimens were maintained.

Intragastric acidity was measured by means of a nasogastric antimony electrode connected to a portable pH Synectics Medical Digitrapper (ED). After the 24-hour monitoring period the $\mathrm{pH}$ data were stored in a computer using the Gastrosoft pHgram software (Synectics).

Electrodes and recorders were calibrated in vitro at $22^{\circ} \mathrm{C}$ using commercial buffer solutions of $\mathrm{pH} 1.07$ and $\mathrm{pH} 7.01$ (Synectics). After calibration, the electrode was passed transnasally and positioned in the body of the stomach, $60 \mathrm{~cm}$ from the nostril. After five minutes the $\mathrm{pH}$ was measured. If the $\mathrm{pH}$ was less than 6.0 for at least five minutes the position was accepted. If the $\mathrm{pH}$ was more then 6.0 radioscopy was performed to check upon and if necessary change the position of the electrode. The distance of the electrode position from the nares was recorded for each subject at the first experiment and kept constant on all test-days.

During the test-days the subjects were ambulatory throughout the whole $\mathrm{pH}$ recording and followed their normal pattern of life. Standard meals and drinks 
were provided during the 24 -hour test period. The study subject recorded smoking and resting periods on a diary card.

The daytime period was defimed as the period between 9 a.m. and midnight, the night-time period as the period between midnight and $6 \mathrm{a} . \mathrm{m}$.

Variables used for the calculations were the individual median $\mathrm{pH}$-value during the entire 24-hour period and the daytime and nighttime periods, respectively.

Serum gastrin was measured immediately before and 15,30 and 60 minutes after eating a standard breakfast containing two slices of white bread, $150 \mathrm{ml}$ of tea, 100 $\mathrm{g}$ of cheese, $16 \mathrm{~g}$ of sugar and $25 \mathrm{~g}$ of butter. Serum gastrin was measured by a sensitive and specific radioimmunoassay, as previously described ${ }^{28}$. The upper limit of normal for the fasting state was $40 \mathrm{pM}$ or $85 \mathrm{pg} / \mathrm{ml}$.

Serum pepsinogen $\mathrm{A}$ and $\mathrm{C}$ levels were only measured in the basal samples, as it has been shown that feeding has no influence on serum pepsinogen concentrations. Serum pepsinogen $A$ and $C$ were measured by a sensitive and specific radioimmunoassay as previously described ${ }^{29}$. The normal range of serum pepsinogen $A$ is $17-120 \mu \mathrm{g} / 1$. The upper limit of normal of serum pepsinogen $C$ is $40 \mu \mathrm{g} / 1$.

The pepsinogen $\mathrm{A} / \mathrm{C}$ ratio was calculated, and the lower limit of normal of the pepsinogen $\mathrm{A} / \mathrm{C}$ ratio is 1.6 .

All samples were measured in duplicate in the same assay.

Helicobacter pylori serology was performed in duplo with heat-inactivated serum samples by a commercial Western blotting for IgG (Helicoblot 2.0). Positive and negative controls were included when the test was performed.

\section{Statistical evaluation}

The $\mathrm{pH}$ data are given as median values. Statistical analysis was performed by means of the Friedman's two-way analysis of variance by ranks with Bonferroni correction; further, the Wilcoxon signed rank test was used to examine paired or unpaired differences.

Gastrin and pepsinogen $\mathrm{A}$ and $\mathrm{C}$ data are given as mean values. Integrated mealstimulated serum gastrin outputs were determined by calculating the area under the serum concentration time curve. Statistical analysis on these data was performed using MANOVA (univariant approach) with Tuckey's correction for the six multiple comparisons. 
Two sided $P$-values $<0.05$ are assumed to indicate statistical significance.

Spearman correlations were calculated between basal serum gastrin levels and serum pepsinogen $\mathrm{A}$ and $\mathrm{C}$ levels respectively, and between integrated serum gastrin levels and serum pepsinogen $\mathrm{A}$ and $\mathrm{C}$ levels respectively.

\section{Ethical considerations}

The study was approved by the Ethics Committee of the University Hospital Maastricht, and written informed consent was obtained from each subject before entering the study.

\section{Results}

All eleven subjects tolerated the experiments well, and no adverse reactions were reported.

\section{Intragastric acidity}

The group median values of the individual median intragastric $\mathrm{pH}$ values during the four different dosing regimens are given in Table V.1, for the total 24-hour period, the daytime period from 09.00 to 24.00 hours, and the night-time period from 00.00 to 06.00 hours.

The decrease in gastric acidity for all three treatments was significant compared to placebo; the significance of the differences between the various treatments is given in Table V.1.

'Thablit $V_{\text {"l: }}$ Median values and ranges for the 24-hr period, night-time, and daytime. $P$ values indicate overall significancy with Manova.

\begin{tabular}{lccccc}
\hline & Placebo & $\begin{array}{c}\text { Ranitidine } \\
\text { 300 mg bid }\end{array}$ & $\begin{array}{c}\text { Omeprazole } \\
\text { 20 mg om }\end{array}$ & $\begin{array}{c}\text { Omeprazole } \\
\text { 40 mg om }\end{array}$ & P \\
\hline pH 9-24 hr & $1.7(0.9-5.6)$ & $3.2(1.9-6.8)^{\mathrm{a}}$ & $5.1(1.3-8.8)^{b}$ & $6.0(2.3-7.2)^{\mathrm{b}, 5}$ & $<0.001$ \\
pH 0-6 hr & $1.7(0.9-5.6)$ & $3.9(1.2-8.5)^{\mathrm{d}}$ & $4.9(1.4-8.7)^{\circ}$ & $4.5(1.6-7.7)^{\mathrm{c}}$ & $<0.01$ \\
pH 24 hrs & $1.7(0.9-4.2)$ & $\mathbf{3 . 7}(1.9-6.8)^{\mathrm{d}}$ & $4.5(1.4-7.6)^{\mathrm{b}}$ & $5.5(2.1-7.1)^{\mathrm{b}, \mathrm{r}}$ & $<0.01$ \\
\hline
\end{tabular}

a $\mathrm{P}<0.05$ compared to placebo; ${ }^{b} \mathrm{P}<0.001$ compared to placebo; $\mathrm{P}<0.01$ compared to ranitidine;

" $\mathrm{P}<0.01$ compared to placebo; ${ }^{*} \mathrm{P}<0.005$ compared to placebo; ${ }^{*} \mathrm{P}<0.05$ compared to ranitidine. 


\section{Serum gastrin}

In the order of $300 \mathrm{mg}$ ranitidine b.d., $20 \mathrm{mg}$ omeprazole $0 . \mathrm{m}$., $40 \mathrm{mg}$ omeprazole o.m., each of the treatments produced a significant increase of basal and mealstimulated gastrin levels compared to the previous one and - indeed-compared to placebo. Thus even on $40 \mathrm{mg}$ omeprazole $0 . \mathrm{m}$. the basal and meal-stimulated gastrin increase was higher than that on $20 \mathrm{mg}$ omeprazole $0 . \mathrm{m} . \quad(P<0.05)$ (Figure V.1). The same was true when meal-stimulated serum gastrin levels were integrated over the period of one hour (Figure V.2).

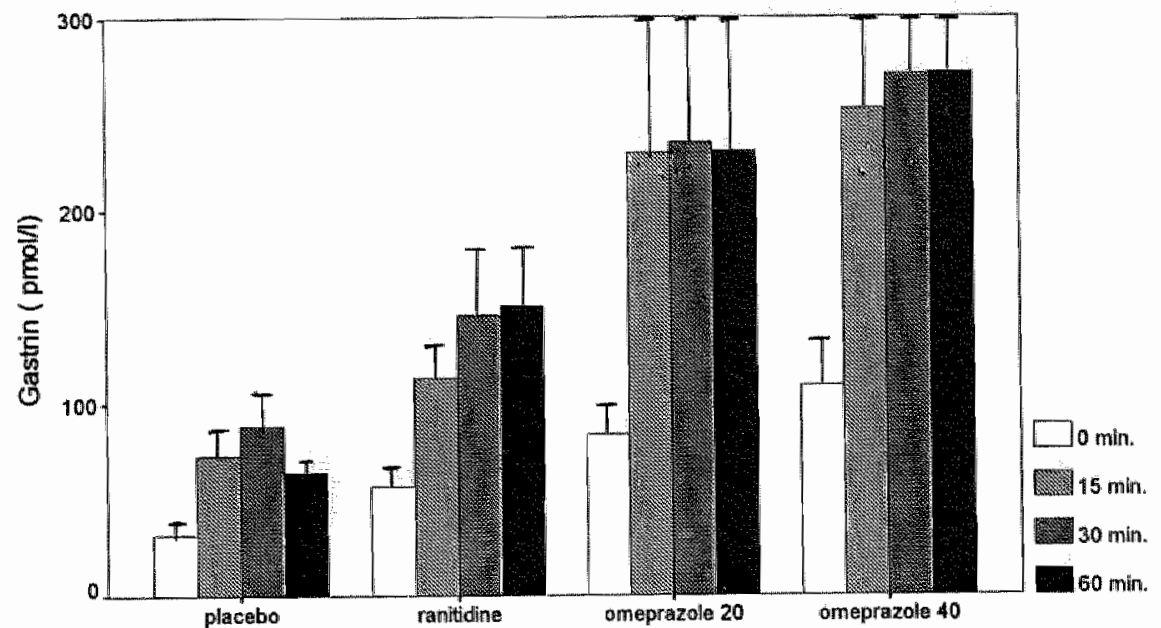

Figure $V_{.1}$ : Mean basal and meal-stimulated serum gastrin levels with SEM after the four different treatments

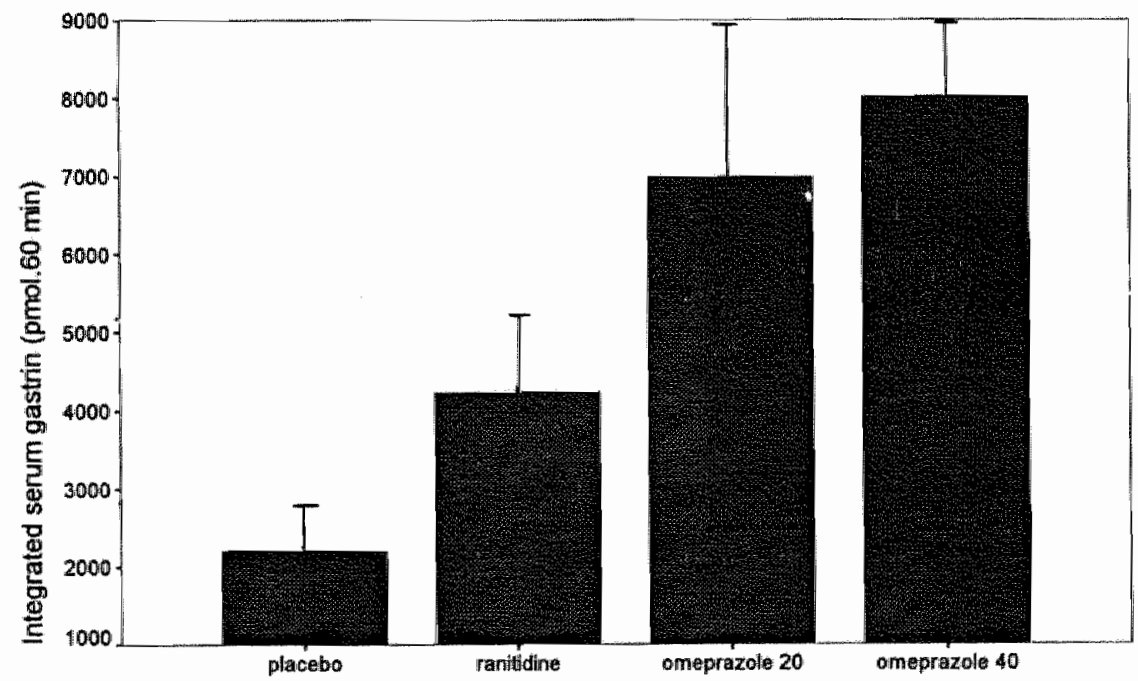

Figure V.2: Mean integrated meal-stimulated senum gastrin levels with SEM after the four different treatments 


\section{Serum pepsinogens}

Serum pepsinogen $A$ and pepsinogen $C$ levels were not increased after ranitidine compared to placebo, but were significantly higher on $20 \mathrm{mg}$ omeprazole and $40 \mathrm{mg}$ omeprazole compared to both placebo and ranitidine $(\mathrm{P}<0.001)$. Serum pepsinogen $A$ and pepsinogen $C$ levels were also significantly higher on $40 \mathrm{mg}$ omeprazole than on $20 \mathrm{mg}$ omeprazole $(\mathrm{P}<0.005$ ) (Figure V.3).

For the pepsinogen $\mathrm{A} / \mathrm{C}$ ratio no significant differences were found between the different treatments $(P=0.08)$.

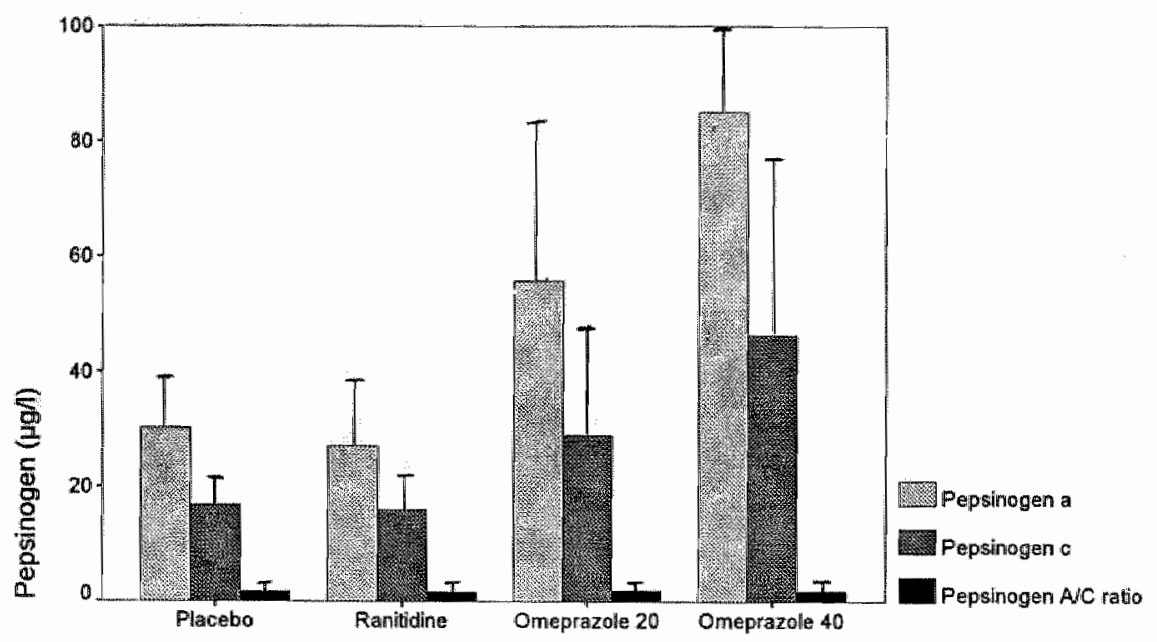

Figure V.3: Mean serum pepsinogen $A$ and senm pepsinogen $C$ levels, and pepsinogen $A / C$ ratio with SEM after the four different treatments

\section{Correlations between serum gastrin and serum pepsinogens}

A positive correlation was found between the integrated serum gastrin levels and the serum pepsinogen A levels $(r=0.40, P<0.01)$ (Figure V.4), and between the integrated serum gastrin levels and the serum pepsinogen $C$ levels $(r=0.50$, $P<0.001$ ), respectively (Figure V.5). 


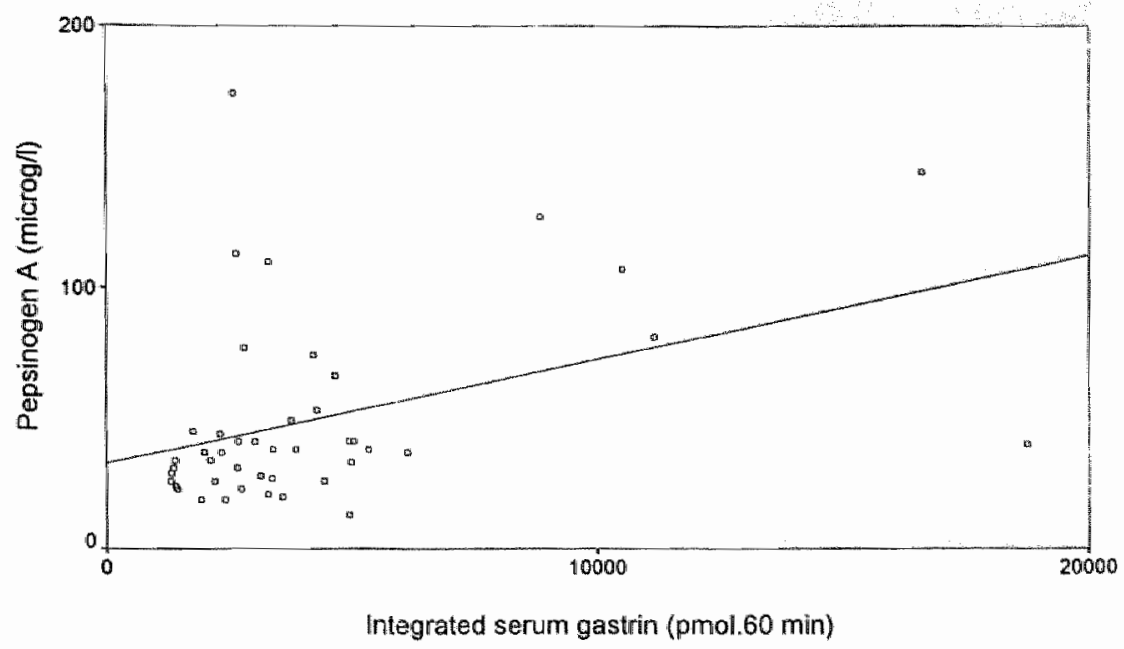

Figure V.4: Correlation between integrated serum gastrin levels and serum pepsinogen A levels $(r=0.40, P<0.01)$

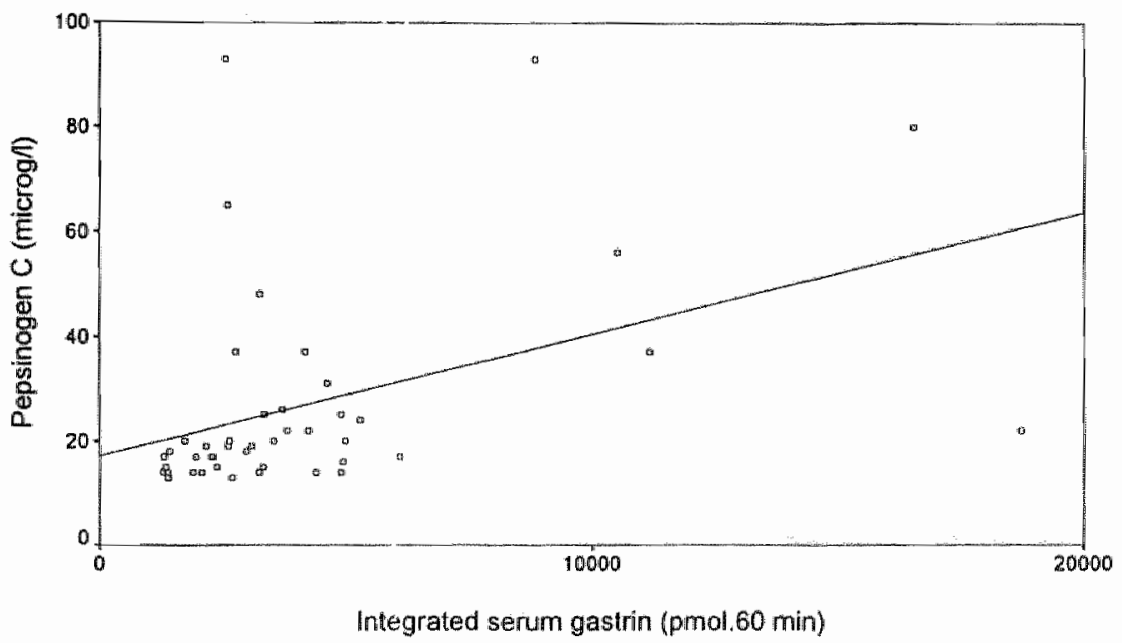

Figure V.5: Correlation between integrated serum gastrin levels and serum pepsinogen C levels $(r=0.50, P<0.001)$ 
As shown in Figure V.6 and V.7, a positive correlation was also found between the basal serum gastrin levels and the serum pepsinogen $A$ and serum pepsinogen $C$ levels $(\mathrm{P}<0.001)$, respectively.

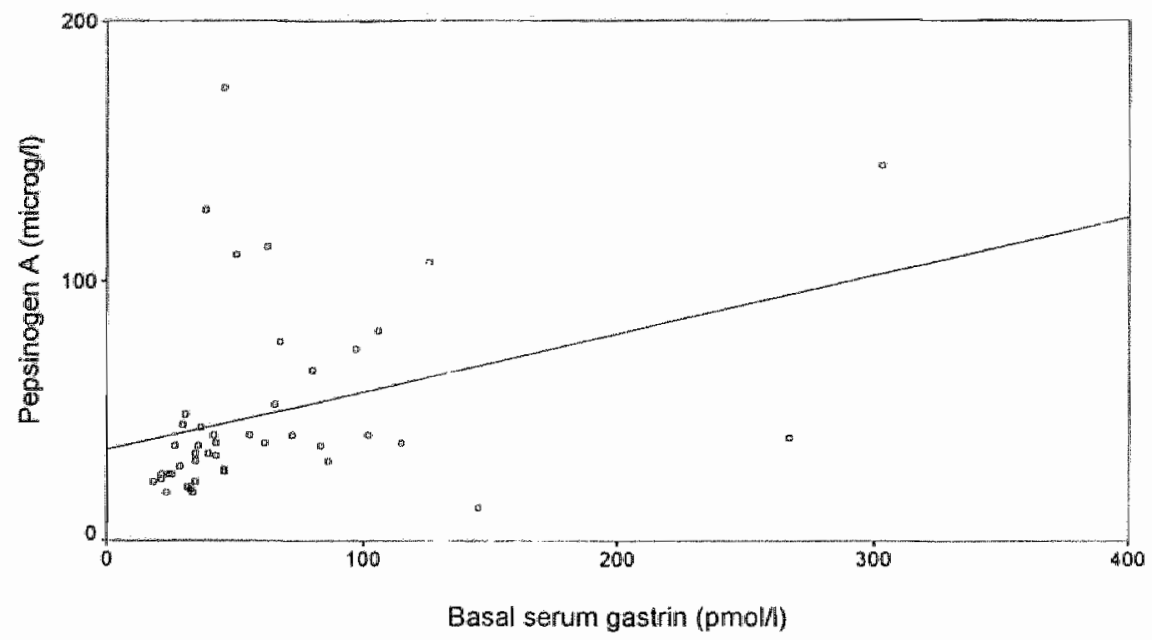

Figure V.6: Correlation between basal serum gastrin levels and senum pepsinogen A levels $(r=0.54, P<0.001)$

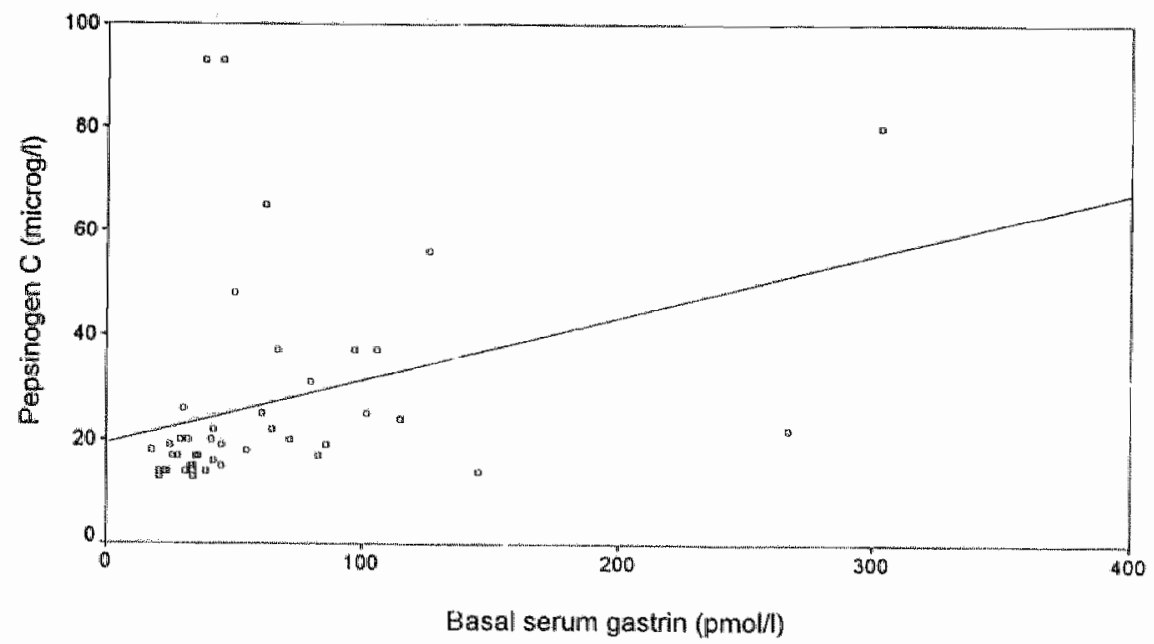

Figure Y.7: Correlation between basal serum gastrin levels and senum pepsinogen $C$ levels $(r=0.57, P<0.001)$ 


\section{Helicobacter pylori serology}

Using Western blotting, 1 of 11 subjects was found to be Helicobacter pylori positive, and 10 were Helicobacter pylori negative.

\section{Discussion}

When strong acid inhibitory drugs were introduced (such as cimetidine in 1976) several fears were expressed concerning possible side-effects of these drugs, such as: the risks of prolonged hypo- or achlorhydria; hypergastrinaemia due to the intervention with the feedback mechanism between intragastric acidity and antral G-cell mass ${ }^{30,31}$. After the introduction of the proton-pump-inhibitors (PPIs) hypergastrinaemia and ECL-cell hyperplasia as a consequence of strong acid inhibition have been extensively discussed ${ }^{\text {b-9.9}}$.

This study has shown for the first time that the increase of basall and mealstimulated serum gastrin follows almost linearly the degree of pharmacological acid inhibition with a difference even between $20 \mathrm{mg}$ omeprazole o.m. and $40 \mathrm{mg}$ omeprazole o.m. In this context it has to be realized that basal gastrin levels appeared only to be mildly or moderately elevated, whereas the integrated mealinduced gastrin levels on the highest dose of omeprazole reaches levels almost four times as high as on placebo.

In addition to its acid stimulating effect, gastrin also has a growth-promoting effect ${ }^{32,33}$. With this in mind, the gradual increase of pepsinogen $A$ as well as of pepsinogen $\mathrm{C}$ (which was correlated to the increase of gastrin levels) possibly reflects hyperplasia and/or hyperactivity of the gastric chief cell population ${ }^{34}$. On the other hand, during potent inhibition of gastric acid secretion the volume of gastric acid secretion is low, and, consequently, the concentration of non-secreted pepsinogens in the gastric gland may increase. The net result may be a backdiffusion of pepsinogens from the gastric mucosa into circulation ${ }^{20,22}$.

Long-term omeprazole therapy in Helicobacter pylori-positive individuals results in corpus gastritis $^{35}$. Gastritis may cause leakage of pepsinogens into the circulation by disintegrated cells. Overgrowth of bacteria other than Helicobacter pylori and subsequent mucosal inflammation may also cause such a leakage. However, because of the strong significant correlation we have found between serum gastrin and serum pepsinogen levels, it seems more probable that the increase pepsinogen levels are a reflection of hyperplasia and/or hyperactivity of the pepsinogen 
producing cells. As pepsinogen $\mathrm{C}$ producing cells are not predominant in the corpus of the stomach there is another argument against the leakage theory ${ }^{18}$.

Gastric acid inhibition lowers mucosal somatostatin not only in the gastric antrum but also in the gastric fundus ${ }^{36}$. Since somatostatin exerts inhibitory effects on the chief cells, it is possible that this is an other explanation for the hypergastrinaemia and hyperpepsinogenaemia ${ }^{3 T}$.

In conclusion, this study confirms that increasing acid inhibition results in basal and particularly meal-induced hypergastrinaemia and hyperpepsinogenaemia, the latter possibly being an expression of a proliferative action on the chief cell mass. It seems unlikely that these changes clinically are of importance in short- and medium-term profound acid inhibition. Whether surveillance of long-term acid inhibitory treatment is necessary can at present not be answered definitively. Recent reports about increased cancer rates in patients with elevated gastrin levels decades before the discovery of a malignant event gives rise to $\operatorname{concern}^{38}$. 


\section{References}

1 Sharma $\mathrm{BK}_{\text {, Walt } \mathrm{RP}}$, Pounder RE et al. Optimal dose of oral omeprazole for maximal 24 hours decrease of intra-gastric acidity. Gut 1984;25:957-64.

2 Chiverton SG, Howden CW, Burget DW, Hunt RW. Omeprazole (20 mg) daily given in the morning or evening: a comparison of effects on gastric acidity, and plasma gastrin and omeprazole concentration. Aliment Pharmacol Ther 1992;6:103-11.

3 Patel $\mathrm{N}$, Ward UM, Brown AK et al. The effect of ranitidine $300 \mathrm{mg}$ at night, ranitidine $300 \mathrm{mg}$ twice daily and placebo on $24 \mathrm{~m}$ intragastric $\mathrm{pH}$ and $24 \mathrm{~h}$ gastrin in healthy subjects. Eur J Gastroenterol Hepatol 1993;5:161-4.

4 Walsh $\mathbb{J H}$, Richardson CT, Fordtran IS. $\mathrm{pH}$ dependence of acid secretion and gastrin release in normal and ulcer subjects. J Clin Invest 1975;55:462-8.

5 Lind $\mathrm{T}$, Cederberg $\mathrm{C}$, Forssell $\mathrm{H}$ et al. Relationship between reduction of acid secretion and plasma gastrin concentration during omeprazole treatment. Scand J Gastroenterol 1988;23:1259-66.

6 Carlsson E, Larsson H, Mattsson $H$ et al. Pharmacology and toxicology of omeprazole, with special reference to the effects on the gastric mucosa. Scand $J$ Gastroenterol 1986;21 (Suppl. 118):31-8.

7 Tielemans Y, Hakanson R, Sundler R et al. Proliferation of enterchromaffinelike cells in omeprazole treated hypergastrinemic rats. Gastroenterology 1989;96:723-9.

8 Lee $H$, Hakanson $\mathrm{R}$, Karlsson $\mathrm{A}$ et al. Lanzoprazole and omeprazole have similar effects on plasma gastrin levels, enterochromaffine-like cells, gastric cells and somatostatin cells in the rat stomach. Digestion 1992;51:125-32.

9 Larsson $H$, Carlsson $E$, Mattsson $H$ et al. Plasma gastrin and gastric enterochromaffine-like cell activation and proliferation. Studies with omeprazole and ranitidine in intact and antrectomized rat. Gastroenterology 1986;90:391-9.

10 Ryberg B, Bishop AE, Bloom SR et al. Omeprazole and ranitidine, antisecretagogues with different modes of action, are equally effective in causing hyperplasia of enterochromaffin-like cells in rat stomach. Regul Pept $1989 ; 25: 235-46$.

11 Kimura K. Effect of somatostatin analogue (SMS 201-995) on antral gastrin cell hyperplasia and hypergastrinemia induced by a histamine H2-receptor antagonist. Scand J Gastroenterol 1993;28:413-7.

12 Borch K, Renvall H, Liedberg G. Gastric endocrine cell hyperplasia and carcinoid tumors in pernicious anemia. Gastroenterology 1985;88:638-48.

13 Carney J, Go V, Fairbanks V et al. The syndrome of gastric argyrophil carcinoid tumors and nonantral gastric atrophy. Ann Int Med 1983;99:761-6.

14 Rode J, Dhillon $A$, Papadaki $L$ et al. Pernicious anaemia and mucosal endocrine cell proliferation of the non-antral stomach. Gut 1986;27:789-98. 
15 Bardman L, Thomsen P, Stadil F. Gastric endocrine cells in omeprazole-treated and untreated patients with the Zollinger-Ellison syndrome. Digestion 1986;35 (Suppl 1): $116-22$.

16 Mignon $M$, Lehy $Y$, Bonnefond $A$ et al. Development of gastric argyrophil carcinoid tumors in a case of Zollinger-Ellison syndrome with primary hyperparathyroidism during long-term antisecretory treatment. Cancer 1987;59:1959-62.

17 Samloff IM. Cellular localization of group I pepsinogens in human gastric mucosa by immunofluorescence. Gastroenterology 1971;61:185-8.

18 Samloff IM, Liebman WM. Cellular localization of the group II pepsinogens in human stomach and duodenum by immunofluorescence. Gastroenterology $1973 ; 65: 36-42$.

19 Festen H, Thijs $\mathbf{J}$, Lamers $\mathrm{C}$ et al. Effect of orall omeprazole on serum gastrin and serum pepsinogen I levels. Gastroenterology 1984;87:1030-4.

20 Ten Kate $\mathbf{R}$, Tuynman $\mathbf{H}$, Festen $\mathbf{H}$ et al. Effect of high dose omeprazole on gastric pepsin secretion and serum pepsinogen lewels in man. Eur J Clin Pharmacol 1988;35:173-6.

21 Festen $\mathrm{H}$, Tuynman $\mathrm{H}$, Defize $\mathbf{J}$ et al. Effect of single and repeated doses of oral omeprazole on gastric acid and pepsin secretion and fasting serum gastrin and serum pepsinogen I levels. Dig Dis Sci 1986;31:561-6.

22 Biemond I, Crobach $L$, Jansen $J$, Lamers $C$. Effect of short-term omeprazole administration on serum pepsinogens in relation to fasting serum gastrin and gastric acid secretion. Eur J Clin Pharmacol 1989;37:345-9.

23 Jansen J, Klinkenberg-Knol E, Meuwissen S et al. Effect of long-term treatment with omeprazole on serum gastrin and serum group $A$ and $C$ pepsinogens in patients with reflux esophagitis. Gastroenterology 1990;99:621-8.

24 Waldum H, Burhol P, Straume B. Serum group I pepsinogens during prolonged infusion of pentagastrin and secretin in man. Scan J Gastroenterol 1979;14:761-8.

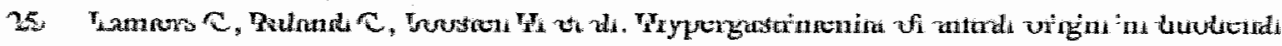
ulcer. Dig Dis Sci 1978;23:998-1002.

26 Lamers C, Jansen J, Rotter J, Samloff I. Serum pepsinogen I in hereditary hypergastrinemic peptic ulcer syndromes. Prog Clin Biol Res 1985;137:273-81.

27 Lamers C, Jansen J, Rotter J, Samloff I. Serum pepsinogen I in familial multiple endocrine neoplasia type I. Dig Dis Sci 1988;33:1274-6.

28 Jansen J, Lamers $C$. Effect of changes in serum calcium on secretin-stimulated serum gastrin in patients with Zollinger-Ellison syndrome. Gastroenterology 1982;83:173-8.

29 Biemond I, Jansen J, Crobach L et al. Radioimmunoassay of human pepsinogen A and pepsinogen C. J Clin Chem Clin Biochem 1989;27:19-25.

30 Ruddell $W$, Axon A, Findley $J$ et al. The effect of cimetidine on the gastric bacterial microflora. Lancet 1980;i:672-4. 
31 Stockbrügger $\mathrm{R}$, Cotton $\mathrm{P}$, Eugenides $\mathrm{N}$ et al. Intragastric nitrites, nitrosamines and bacterial overgrowth during cimetidine treatment. Gut 1982;23:1048-54.

32 D'Adda $T$, Pilato $F$, Lazzaroni $M$ et al. Ultrastructural morphomethry of gastric endocrine cells before and after omeprazole. Gastroenterology 1991;100:1563-70.

33 Tielemans $Y$, Axelson $J$, Sundler F et al. Serum gastrin concentration affects the self replication rate of the enterochromaffin-like cells in the rat stomach. Gut 1990;31:274-8.

34 Lamberts $R$, Creutzfeldt W, Strüber $H$ et al. Long-tern omeprazole therapy in peptic ulcer disease: gastrin, endocrine cell growth, and gastritis. Gastroenterology 1993; 104:1356-70.

35 Kuipers E, Klinkenberg-Knol E, Havu N et al. Helicobacter pylori and development of atrophic gastritis during acid supressive therapy. Lancet 1995;345:1525-8.

36 Allen J, Bishop A, Daly $M$ et al. Effect of inhibition of acid secretion on the regulatory peptides in the rat stomach. Gastroenterology 1986;90:970-7.

37 Muller M, Defize J, Hunt R. Control of pepsinogen synthesis and secretion. Gastroenterology Clinics of North America 1990;19:27-40.

38 Smith J, Kramer S, Demers 1. Effects of gastrin and difluoromethylomithine on growth of human colon cancer Dig Dis Sci 1993;38:520-8. 


\section{Chapter VI}

\section{Twenty-four-hour intragastric pH, basal and meal-stimulated serum gastrin, and plasma chromogranin A after short- term acid inhibition}

GMP Houben, I Biemond, G Lundqvist,

D Jonkers, RW Stockbrügger 


\begin{abstract}
Background: Gastric acid inhibition results in increases of serum gastrin. Circulating chromogranin $\mathrm{A}(\mathrm{CgA})$ have been used as a marker for neuroendocrine tumour growth. CgA plasma levels may prove to be a useful marker for the enterochromaffine-like (ECL) cell population in the stomach.
\end{abstract}

Aim: We evaluated the effects of three regimens of medical acid inhibition in a doubleblind, placebo-controlled, multiple cross-over study to elucidate the effects of acid inhibition on serum gastrin and plasma $\mathrm{CgA}$ levels.

Methods: Intragastric 24-hour $\mathrm{pH}$ monitoring was performed, and basal and meal stimulated serum gastrin and plasma $\mathrm{CgA}$ before and after therapy were measured in 11 healthy subjects. Each subject received for 2 weeks $300 \mathrm{mg}$ ranitidine b.d., $20 \mathrm{mg}$ omeprazole o.m., $40 \mathrm{mg}$ omeprazole o.m., and placebo, respectively.

Results: $300 \mathrm{mg}$ ranitidine b.d., $20 \mathrm{mg}$ omeprazole and $40 \mathrm{mg}$ omeprazole all decreased 24-hour acidity significantly when compared to placebo. In order of $300 \mathrm{mg}$ ranitidine b.d., $20 \mathrm{mg}$ omeprazole $0 . \mathrm{m}$., $40 \mathrm{mg}$ omeprazole $40 \mathrm{o} . \mathrm{m}$., each of the treatments produced a significant increase of basal, meal-stimulated and integrated meal-stimulated serum gastrin compared to the previous one and compared to placebo. Plasma CgA levels and delta $\mathrm{CgA}$ levels were significantly higher after $20 \mathrm{mg}$ omeprazole o.m. and $40 \mathrm{mg}$ omeprazole o.m., respectively, compared to placebo and $300 \mathrm{mg}$ ranitidine b.d., respectively. Positive correlations were found between basal and integrated serum gastrin levels, respectively, and plasma $\mathrm{CgA}$ levels and delta $\mathrm{CgA}$ levels, respectively.

Conclusion: Increasing acid inhibition leads to basal and particularly meal-induced hypergastrinaemia and increased plasma $\mathrm{CgA}$ levels, the latter probably being an expression of a proliferative action of gastrin on the ECL-cells. 


\section{Introduction}

Gastro-oesophageal reflux-disease (GORD), gastric ulcer and duodenal ulcer are acid-related diseases. Modern acid inhibitory drugs, such as proton pump inhibitors and histamine-2-receptor antagonists are able to profoundly reduce gastric acid secretion $^{1-3}$.

Profound acid inhibition led to increases in serum gastrin due to the feedback mechanism between intragastric acidity and antral gastrin release ${ }^{4,5}$. In rats, hypergastrinaemia induced by long-term administration of omeprazole led to enterochromaffin-like cell (ECL-cell) hyperplasia and, subsequently, gastric carcinoid formation ${ }^{6,7}$. Additional studies have shown that these effects are not restricted to omeprazole therapy but are also found during treatment with other proton pump inhibitors ${ }^{8}$ and high doses of $\mathrm{H} 2$-receptor antagonists ${ }^{9-11}$, confirming that they are secondary to long-term profound acid inhibition. Although carcinoids have not been observed during omeprazole therapy in man, the possibility cannot be excluded that long term pronounced hypergastrinaemia may increase the risk of carcinoid formation.

Chromogranin A (CgA) is an acidic glycoprotein with a molecular weight of 49000 D that was characterized by Helle in $1966^{12}$. It has a wide distribution in peptide producing endocrine and neuroendocrine cells ${ }^{13.14}$. Antibodies against chromogranins have been used for immunohistochemical staining of endocrine tissue and tumours of neuroendocrine origin ${ }^{15,16}$. Furthermore, measurements of circulating $\mathrm{CgA}$ have been used as a reliable marker for neuroendocrine tumour growth ${ }^{17-20}$. In this light, $\mathrm{CgA}$ plasma levels may prove to be a useful marker for the ECL-cell population in the stomach ${ }^{21,22}$.

Optimal inhibition of gastric acid secretion has to provide a maximal healing rate of target lesions, but to avoid side-effects as much as possible. This is particularly important in disorders necessitating long-term treatment such as GORD. We evaluated the effects of three different regimens of supposedly strong acid inhibition on 24-hour intragastric $\mathrm{pH}$, on basal and meal stimulated serum gastrin, and on plasma chromogranin A levels, in order to see whether these forms of treatment would induce hypergastrinaemia and subsequent ECL cell hyperactivity. To our knowledge, a direct comparison of the commonly used drug regimens under this aspect has not been published so far. 


\section{Subjects and methods}

This study was a randomized, double-blind, 4-way cross-over, single center study in 11 healthy volunteers ( 7 females, 4 males; age 20-41 years). Each subject received four drug regimens in a random order, $300 \mathrm{mg}$ ranitidine b.d., $20 \mathrm{mg}$ omeprazole $0 . \mathrm{m} ., 40 \mathrm{mg}$ omeprazole o.m., and placebo. Each regimen was given for two weeks. Wash-out periods of 2 weeks were maintained between the dosing regimens.

Intragastric acidity was measured by means of a nasogastric antimony electrode connected to a portable pH Synectics Medical Digitrapper (ED). After the 24-hour monitoring period the $\mathrm{pH}$ data were stored in a computer and evaluated with Gastrosoft pHgram software (Synectics).

Electrodes and recorders were calibrated in vitro at $22^{\circ} \mathrm{C}$ using commercial buffer solutions of $\mathrm{pH} 1.07$ and $\mathrm{pH} 7.01$ (Synectics). After calibration, the electrode was passed transnasally and positioned in the body of the stomach, $60 \mathrm{~cm}$ from the nostril. After five minutes the $\mathrm{pH}$ was measured. If the $\mathrm{pH}$ was less than 6.0 for at least five minutes the position was accepted. If the $\mathrm{pH}$ was more than 6.0 radioscopy was performed to check upon the position of the electrode. The distance of the final electrode position from the nares was recorded for each subject at the first experiment and kept constant on all test-days.

During the test-days the subjects were ambulatory throughout the whole $\mathrm{pH}$ recording and followed their normal pattern of life. Standard meals and drinks were provided during the 24 -hour test period. The study subject recorded smoking and resting periods on a diary card.

The daytime period was defined as the period between 9 a.m. and midnight, the nighttime period as the period between midnight and 6 a.m. Variables used for the calculations were the individual median pH-value during the entire 24-hour period and the daytime and nighttime periods, respectively.

Serum gastrin was measured on the last day of each treatment period, immediately before and 15,30 and 60 minutes after eating a standard breakfast containing two slices of white bread, $150 \mathrm{ml}$ of tea, $100 \mathrm{~g}$ of cheese, $16 \mathrm{~g}$ of sugar and $25 \mathrm{~g}$ of butter. Serum gastrin was measured by a sensitive and specific radioimmunoassay, as previously described ${ }^{23}$. The upper limit of normal for the fasting state was $40 \mathrm{pM}$ or $85 \mathrm{pg} / \mathrm{ml}$. 
Basal plasma chromogranin $\mathrm{A}(\mathrm{CgA})$ was measured on the first day and on the last day of each treatment period, by a sensitive and specific radioimmunoassay as previously described ${ }^{20}$. The upper limit of normal for $\mathrm{CgA}$ was $4 \mathrm{nmol} / \mathrm{l}$. All samples were measured in duplicate in the same assay.

Delta $\mathrm{CgA}$, the difference between $\mathrm{CgA}$ before and after treatment, was also calculated.

In each volunteer, Helicobacter pylori serology was performed in duplo with heatinactivated serum samples by a commercial Western blotting for IgG (Helicoblot 2.0). Positive and negative controls were included when the test was performed.

\section{Statistical evaluation}

The group $\mathrm{pH}$ data are given as median values. Statistical analysis was performed by means of the Friedman's two-way analysis of variance by ranks with Bonferroni correction; furthermore, the Wilcoxon signed rank test was used to examine paired or unpaired differences.

Gastrin and $\mathrm{CgA}$ data are given as mean values. Integrated meal-stimulated serum gastrin outputs were determined by calculating the area under the serum concentration time curve. Statistical analysis on these data was performed using MANOVA (univariant approach) with Tuckey's correction for the six multiple comparisons.

Two-sided $\mathrm{P}$-values $<0.05$ are assumed to indicate statistical significance.

Spearman correlations were calculated between basal serum gastrin levels and integrated serum gastrin levels of day 14 , respectively, and $\mathrm{CgA}$ levels of day 14 as well as delta $\mathrm{CgA}$ levels.

\section{Ethical considerations}

The study was approved by the Ethics Committee of the University Hospital Maastricht, and written informed consent was obtained from each subject before entering the study.

\section{Results}

All eleven subjects tolerated the experiments well, and no adverse reactions were reported. 


\section{Intragastric acidity}

The group median value of the individual median intragastric $\mathrm{pH}$ values during the four different dosing regimens are given in Table VI.1, for the total 24-hour period, the daytime period, and the night-time period.

The decrease in gastric acidity for all three treatments was significant compared to placebo; the significance of the differences between the various treatments is given in Table VI.1.

Table W1: Median values and ranges for the 24-hr period, night-time, and daytime $p$ values indicate overall significancy with Manova

\begin{tabular}{cccccc}
\hline & Placebo & $\begin{array}{c}\text { Ranitidine } \\
\mathbf{3 0 0} \mathbf{m g} \text { bid }\end{array}$ & $\begin{array}{c}\text { Omeprazole } \\
\mathbf{2 0} \mathbf{~ m g ~ o m ~}\end{array}$ & $\begin{array}{c}\text { Omeprazolle } \\
\mathbf{4 0} \mathbf{~ m g ~ o m ~}\end{array}$ & P \\
\hline pH 9-24 hr & $1.7(0.9-5.6)$ & $3.2(1.9-6.8)^{\mathrm{a}}$ & $5.1(1.3-8.8)^{\mathrm{b}}$ & $6.0(2.3-7.2)^{\mathrm{b} . \mathrm{c}}$ & $<0.001$ \\
pH 0-6 hr & $1.7(0.9-5.6)$ & $3.9(1.2-8.5)^{\mathrm{d}}$ & $4.9(1.4-8.7)^{\mathrm{c}}$ & $4.5(1.6-7.7)^{\mathrm{c}}$ & $<0.01$ \\
$\mathrm{pH} \mathrm{24} \mathrm{hrs}$ & $1.7(0.9-4.2)$ & $3.7(1.9-6.8)^{\mathrm{d}}$ & $4.5(1.4-7.6)^{\mathrm{b}}$ & $5.5(2.1-7.1)^{\mathrm{b} . \mathrm{f}}$ & $<0.01$ \\
\hline
\end{tabular}

${ }^{2} \mathrm{P}<0.05$ compared to placebo; ${ }^{\mathrm{D}} \mathrm{P}<0.001$ compared to placebo; " $\mathrm{P}<0.01$ compared to ranitidine;

i $\mathrm{P}<0.01$ compared to placebo; ${ }^{\circ} \mathrm{P}<0.005$ compared to placebo; $" \mathrm{P}<0.05$ compared to ranitidine.

\section{Serum gastrin}

In order of ranitidine $300 \mathrm{mg} \mathrm{b.d.,} 20 \mathrm{mg}$ omeprazole o.m., $40 \mathrm{mg}$ omeprazole o.m., each of the treatments generated a significant increase of basal and meal stimulated gastrin levels compared to the previous one(s) and - indeed - compared to placebo. The same was true when meal-stimulated serum gastrin levels were integrated over the period of one hour (Table VI.2).

\section{Plasma Chromogranin A}

The $\mathrm{CgA}$ levels before and after the four different treatment regimens are given in Figure VI.1. CgA levels are significantly higher after $20 \mathrm{mg}$ omeprazole o.m. and $40 \mathrm{mg}$ omeprazole $0 . \mathrm{m}$. , respectively, compared to placebo $(\mathrm{P}<0.05)$ and $300 \mathrm{mg}$ ranitidine b.d. $(\mathrm{P}<0.05)$, respectively.

Delta CgA after the different treatment regimens are given in Table VI.2. Delta $\mathrm{CgA}$ are significantly higher on $20 \mathrm{mg}$ omeprazole o.m. and $40 \mathrm{mg}$ omeprazole $0 . \mathrm{m}$., respectively, compared to placebo $(\mathrm{P}<0.05, \mathrm{P}<0.01)$ and $300 \mathrm{mg}$ ranitidine b.d. $(\mathrm{P}<0.05, \mathrm{P}=0.005)$, respectively. 
Table VI.2: Mean (SEM) basal, postprandial, and integrated (AUC) senum gastrin lewels, and plasma chromogranin A and delta chromogranin A levels

\begin{tabular}{|c|c|c|c|c|}
\hline GASTRIN & PLACEBO & $\begin{array}{l}\text { RANITIDINE } \\
300 \mathrm{mg} \text { bid }\end{array}$ & $\begin{array}{l}\text { OMEPRAZOLE } \\
20 \mathrm{mg} \mathrm{om}\end{array}$ & $\begin{array}{l}\text { OMEPRAZOLE } \\
40 \mathrm{mg} \text { on }\end{array}$ \\
\hline 0 min. & $32(3)$ & $57(11)^{d}$ & $83(18)^{d}$ & $109(24)^{\mathrm{d}, \mathrm{sin}}$ \\
\hline $15 \mathrm{~min}$. & $73(16)$ & $113(17)^{0}$ & $230(70)^{d . t}$ & $252(55)^{\text {d. hith }}$ \\
\hline $30 \mathrm{~min}$. & $88(19)$ & $146(28)^{d}$ & $235(60)^{\mathrm{di}}$ & $270(53)^{\text {dis.th }}$ \\
\hline $60 \mathrm{~min}$. & $64(8)$ & $150(29)^{d}$ & $230(60)^{\mathrm{det}}$ & $270(58)^{d .8 .19}$ \\
\hline AUC & $2201(358)$ & $4223(708)^{d}$ & $6972(1868)^{d, e}$ & $8009(1598)^{1,8}$ \\
\hline CHROMOGRANIN A & $3.22(0.40)$ & $3.19(0.17)$ & $4.53(0.63)^{0.6}$ & $4.90(0.63)^{\mathrm{s} .}$ \\
\hline DELTA CgA & $-0.06(0.52)$ & $0.08(0.23)$ & $1.46(0.50)^{4,6}$ & $2.19(0.64)^{\mathrm{b}, \mathrm{s}, \mathrm{h}}$ \\
\hline
\end{tabular}

${ }^{2} \mathrm{P}<0.05$ compared to placebo; ${ }^{b} \mathrm{P}<0.01$ compared to placebo; ${ }^{\mathrm{c}} \mathrm{P}<0.005$ compared to placebo;

${ }^{\circ} \mathrm{P}<0.001$ compared to placebo; ${ }^{\mathrm{e}} \mathrm{P}<0.05$ compared to ranitidine; ${ }^{t} \mathrm{P}<0.01$ compared to ranitidine;

8. $\mathrm{P}<0.001$ compared to ranitidine; ${ }^{\mathrm{h}} \mathrm{P}<0.05$ compared to omeprazole $20 \mathrm{mg}$

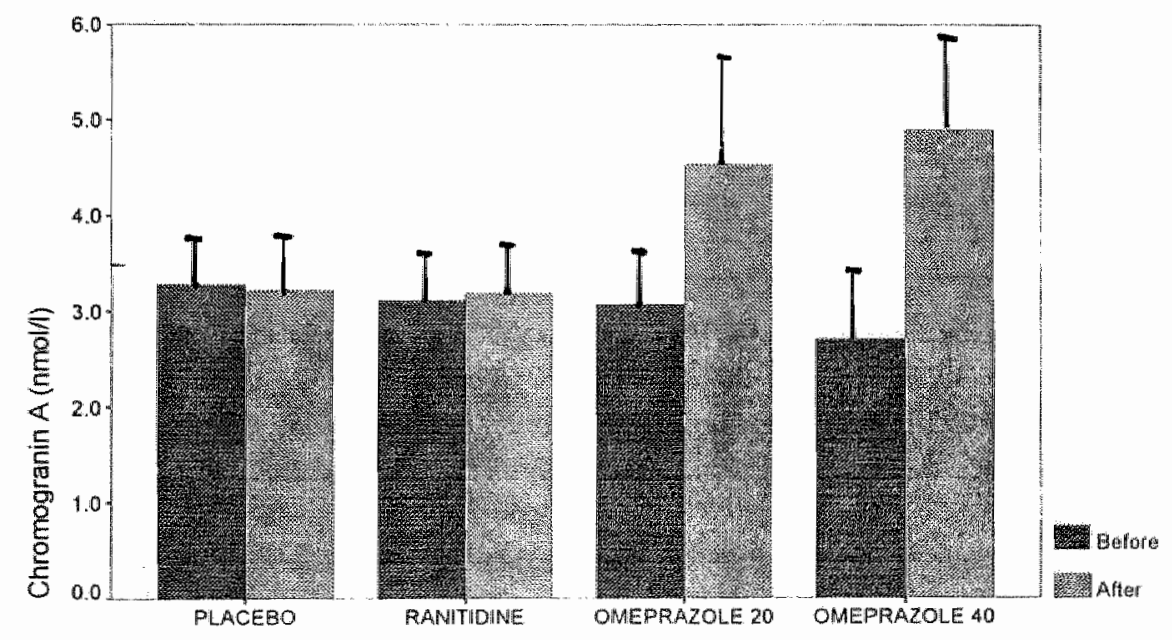

Figure VI.1: Mean plasma chromogranin A levels with SEM before and after the four different treatments 


\section{Correlations between serum gastrin and serum chromogranin A}

A positive correllation was found between the basal serum gastrin levels and the CgA levels $(r=0.36, P<0.05)$ (Figure VI.2), and between the integrated serum gastrin levels and the plasma $\mathrm{CgA}$ levels $(\mathrm{r}=0.49, \mathrm{P}=0.001)$, respectively (Figure VI.3). As shown in Figure VI.4, a positive correlation was also present between integrated serum gastrin levels and delta $\mathrm{CgA}$ levels $(\mathrm{r}=0.47, \mathrm{P}<0.001)$.

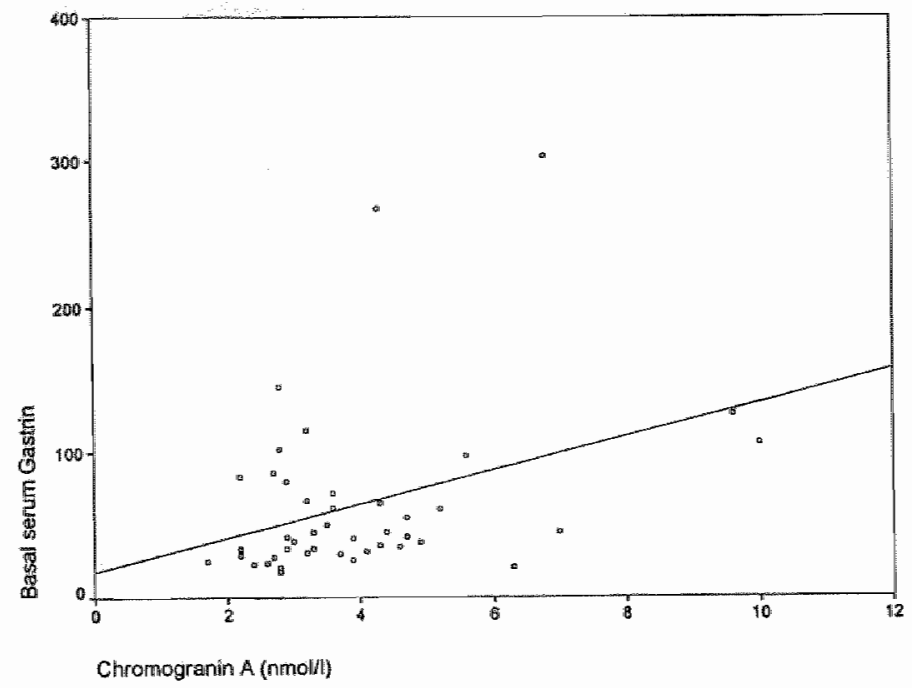

Figure VI.2: Correlation between plasma chromogranin A lewels and basal serum gastrin levels $(r=0.36, P<0.05)$

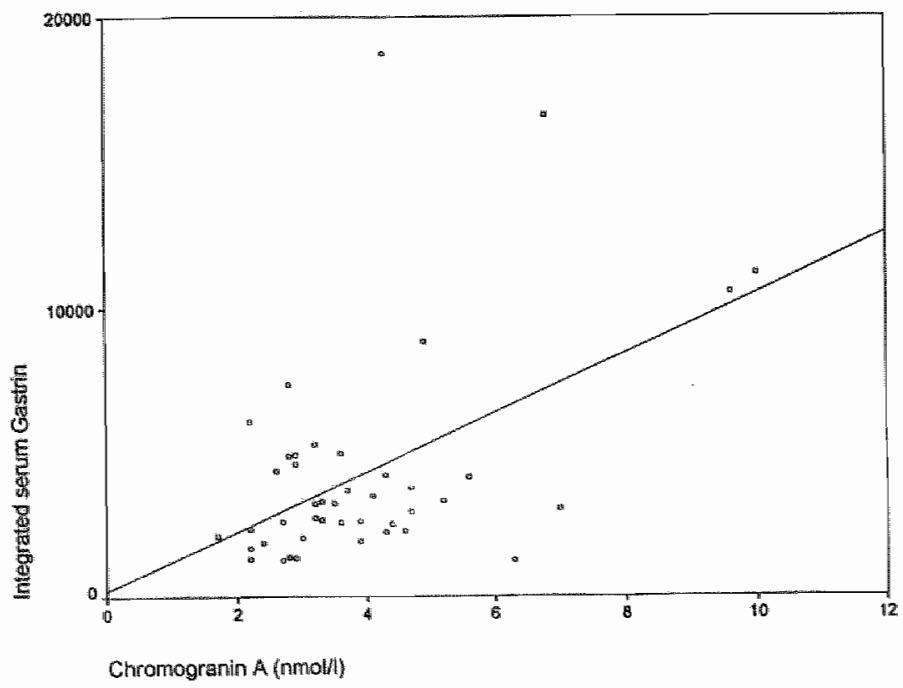

Figure VI.3: Correlation between plasma chromogranin A levels and integrated serum gastrin levels $(r=0.49, P<0.001)$ 


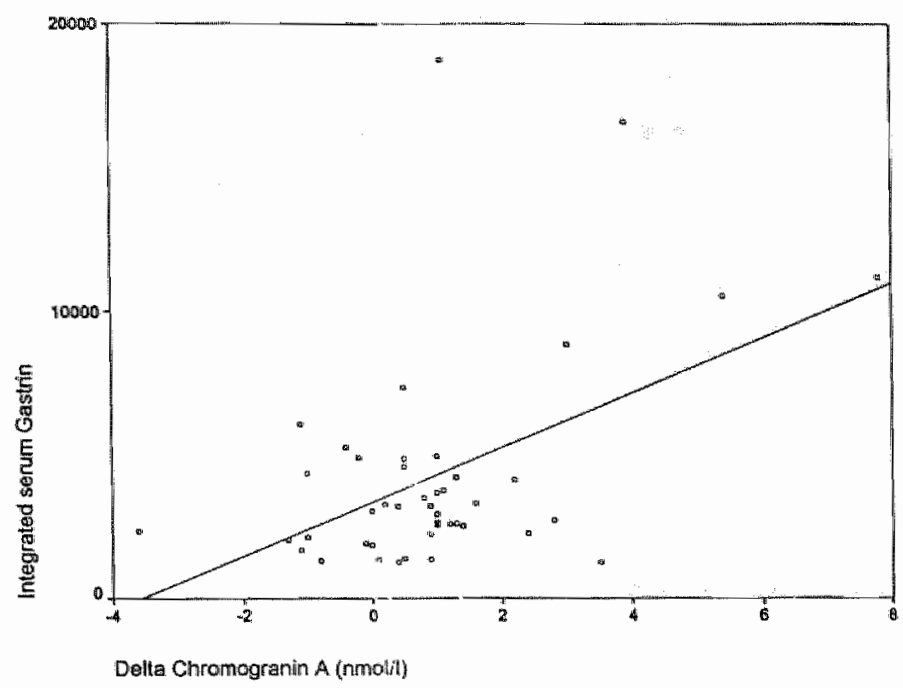

Figure VI.4: Correlation between delta chromogranin A levels and integrated serum gastrin levels $(r=0.47, P=0.001)$

\section{Helicobacter pylori serology}

Using Western blotting, 1 of 11 subjects was found to be Helicobacter positive, and 10 were Helicobacter negative.

\section{Discussion}

When strong acid inhibitory drugs were introduced (such as cimetidine in 1976) amongst the fears concerning possible side-effects of these drugs was the risk of prolonged hypo- or achlorhydria with rise in serum gastrin levels due to the feedback mechanism between the intragastric acidity and the antral G-cell mass ${ }^{24-25}$. In fact, after the introduction of the proton-pump-inhlbitors (PPIs) hypergastrinaemia and subsequent ECL-cell hyperplasia have been extensively discussed ${ }^{6-9}$.

This study has shown that the increase of basal and meal-stimulated serum gastrin almost linearly follows the degree of pharmacological acid inhibition. Whereas post-treatment basal gastrin levels appeared only to be mildly or moderately elevated, the meal induced integrated gastrin release after the highest dose of omeprazole reached levels almost four times as high as after placebo. 
Gastrin has a documented trophic effect ${ }^{26.27}$. In man it acts as a stimulator of the ECL-cell growth and function ${ }^{28-30}$. If the gastrin stimulation is sustained, the ECLcells of the gastric oxyntic mucosa undergo a process of adaptation leading from increased secretory activity (hyperfunction), through hypertrophy, to ECL-cell hyperplasia ${ }^{31}$ and even dysplasia and carcinoid tumour formation ${ }^{32-34}$. Rodents longterm treated with $\mathrm{H} 2$-receptor antagonists or proton pump inhibitors can develop gastric carcinoid tumours ${ }^{7,8,35,36}$. In humans, carcinoid tumours derived from ECLcell hyperplasia have been reported in patients with type A autoimmune chronic atrophic gastritis or with the Zollinger-Ellison syndrome as part of the type I multiple endocrine neoplasia (MEN I) ${ }^{37-39}$. Waldum et al. found evidence of ECLcell derived tumour cells in $40 \%$ of diffuse gastric carcinomas and concluded that a proportion of diffuse gastric carcinomas may originate from ECL-cells ${ }^{40.41}$. He also suggested that, given the slow-growing rate of such malignancies, even modest gastrin elevations over many years may contribute to the pathogenesis of these tumours $^{21}$. At the present date, from a number of clinical studies it appears probable that the hypergastrinaemia and the ECL-cell hyperplasia related to profound gastric inhibition are self-limiting processes and have only a moderate range $26,29,42,43$.

Whether specific markers of cell populations can improve the future diagnosis and clinical monitoring of gastric pre-neoplastic lesions is a matter of debate. Recently, increased plasma levels of $\mathrm{CgA}$ have been reported in neuroendocrine gastrointestinal tumours ${ }^{19,20}$. It is well established that $\mathrm{CgA}$ is released from gastrinoma cells as well as from ECL-cells, while gastrin is only secreted from the gastrinoma cells ${ }^{44,45}$. In the study performed by Stabile et al. ${ }^{44}$ in gastrinoma patients, no correlation was found between plasma $\mathrm{CgA}$ and gastrin levels. The elevated $\mathrm{CgA}$ concentrations were reduced by gastrectomy alone. The authors concluded that the source of the increased CgA probably was the ECL-cell hyperplasia stimulated by the hypergastrinaemia rather than the gastrinoma itself. Thus CgA could be a useful marker for the size and function of the ECL-cell population.

This study, involving healthy volunteers and short-term acid inhibition, is the first study showing a correlation between serum gastrin levels and plasma CgA levels. The question arises whether after long-term acid inhibition plasma CgA levels remain elevated or tend to increase further. In a recent study by Waldum et al. ${ }^{46}$ plasma $\mathrm{CgA}$ levels were correlated with $\mathrm{CgA}$ concentrations in biopsies taken from the oxyntic mucosa of the stomach. In their opinion and also in ours in the future plasma $\mathrm{CgA}$ levels can be used as a marker for ECL-cell function as a non-invasive instrument for monitoring this special side-effect of gastric acid inhibition. 
In conclusion, this study confirms that increasing acid inhibition results in basal and particularly meal-induced hypergastrinaemia and increased plasma $\mathrm{CgA}$ levels, the latter probably being an expression of a proliferative action on the ECL-cells. It seem unlikely, that these changes are of importance in short- and medium-term profound acid inhibition. Whether surveillance of long-term treatment is necessary can presently not be definitively answered. Recent reports about increased cancer rates in patients with elevated gastrin levels decades before a malignant event was discovered may be a warning sign ${ }^{47}$. 


\section{References}

1 Sharma BK, Walt RP, Pounder RE et al. Optimal dose of oral omeprazole for maximal 24 hours decrease of intragastric acidity. Gut 1984;25:957-64.

2 Chiverton SG, Howden CW, Burget DW, Hunt RW Omeprazole (20 mg) daily given in the morning or evening: a comparison of effects on gastric acidity, and plasma gastrin and omeprazole concentration. Aliment Pharmacol Ther $1992 ; 6: 103.7-11$.

3 Patel $\mathbb{N}_{,}$Ward UM, Brown AK et al. The effect of ranitidine $300 \mathrm{mg}$ at night, ranitidine $300 \mathrm{mg}$ twice daily and placebo on $24 \mathrm{~h}$ intragastric $\mathrm{pH}$ and $24 \mathrm{~h}$ gastrin in healthy subjects. Eur I Gastroenterol Hepatol $1993 ; 5: 161-4$.

4 Walsh JH, Richardson CT, Fordtran IS. pH dependence of acid secretion and gastrin release in normal and ulcer subjects. J Clin Invest 1975;55:462-8.

5 Lind $T$, Cederberg $C$, Forssell $H$ et al. Relationship between reduction of acid secretion and plasma gastrin concentration during omeprazole treatment. Scand $J$ Gastroenterol 1988;23:1259-66.

6 Carlsson E, Larsson $\mathrm{H}$, Mattsson $\mathrm{H}$ et al. Pharmacology and toxocology of omeprazole, with special reference to the effects on the gastric mucosa. Scand J Gastroenterol 1986;21 (Suppl. 118):31-8.

7 Tielemans $Y$, Hakanson $R$, Sundler $R$ et al. Proliferation of enterochromaffin-like cells in omeprazole treated hypergastrinemic rats. Gastroenterology 1989;96:723-9.

8 Lee H, Hakanson R, Karlsson A et al. Lanzoprazole and omeprazole have similar effects on plasma gastrin levels, enterochromaffinelike-cells, gastric cells and somatostatin cells in the rat stomach. Digestion 1992;51:125-32.

9 Larsson $H$, Carlsson $E$, Mattsson $H$ et al. Plasma gastrin and gastric enterochromaffine-like cell activation and prolliferation. Studies with omeprazole and ranitidine in intact and antrectomized rat. Gastroenterology 1986;90:391-9.

10 Ryberg B, Bishop AE, Bloom SR et al. Omeprazole and ranitidine, antisecretagogues with different modes of action, are equally effective in causing hyperplasia of enterochromaffin-like cells in rat stomach. Regul Pept $1989 ; 25: 235-46$.

11 Kimura K. Effect of somatostatin analogue (SMS 201-995) on antral gastrin cell hyperplasia and hypergastrinemia induced by a histamine H2-receptor antagonist. Scand J Gastroenterol 1993;28:413-7.

12 Helle KB. Some chemical and physical properties of the soluble protein fraction of bovine adrenal chromaffin granules. Mol pharmacol 1966;2:298-310.

13 O'Conner $\mathbb{D T}$. Chromogranin." widespread immunoreactivity in polypeptide hormone producing tissues and in serum. Regul Pept 1983;6:263-80.

14 O'Conner DT, Burton D, Deftos LJ. Chromogranin A: immunohistology reveals its universal occurence in normal polypeptide hormone producing endocrine glands. Life Sci $1983 ; 33: 1657-63$. 
15 O'Conner DT, Deftos LJ. Secretion of chromogranin A by peptide-producing endocrine neoplasms. N Engl J Med 1986;314:1145-51.

16 Eriksson $\mathrm{B}$, Arnberg $\mathrm{H}$, Oberg $\mathrm{K}$ et al. Chromogranins - new sensitive markers for neuroendocrime tumours. Acta Oncol 1989;28:325-9.

17 Deftos LJ. Chromogranin A: its role in endocrine function and as an endocrine and neuroendocrine tumor marker. Endocrine Review 1991;12:181-7.

18 Wiedenmann $\mathrm{B}$, Waldherr $\mathrm{R}$, Buhr $\mathrm{H}$ et al. Identification of gastroenteropancreatic neuroendocrine cells in normal and neoplastic human tissue with antibodies against synaptophysin, chromogranin A, secretogranin I (chromogranin B), and secretogranin II. Gastroenterol 1988;95:1364-74.

19 Syversen U, Mignon M, Bonfils S et al. Chromogranin A and pancreastatin-like immunoreactivity in serum of gastrinoma patients. Acta Oncol 1993;32:161-5.

20 Stridsberg M, Oberg K, Li Q et al. Measurement of chromogranin A, chromogranin B (sectetogranin I), chromogranin C (secretogranin II) and pancreastatin in plasma and urine from patients with carcinoid tumours. J Endocrinol 1995;144:49-59.

21 Waldum HL, Brenna E, Kleveland PM et al. Review article:the use of gastricinhibitory drugs - physiological and pathophysiological considerations. Aliment Pharmacol Ther 1993;7:589-96.

22 Oberg K. Biological aspects of neuroendocrine gastro-enteropancreatic tumours. Digestion 1996:57 (Suppl 1):42-4.

23 Jansen J, Lamers C. Effect of changes in serum calcium on secretin-stimulated serum gastrin in patients with Zollinger-Ellison syndrome. Gastroenterology 1982;83:173-8.

24 Ruddell W, Axon A, Findley $J$ et al. The effect of cimetidine on the gastric bacterial microflora. Lancet $1980 ; \mathrm{i}: 672-4$.

25 Stockbrügger R, Cotton $\mathrm{P}$, Eugenides $\mathbf{N}$ et al. Intragastric nitrites, nitrosamines, and bacterial overgrowth during cimetidine treatment. Gut 1982;23:1048-54.

$26 D^{\prime}$ Adda $T$, Pilato $F$, Lazzaroni $M$ et al. Ultrastructural morphomethry of gastric endocrine cells before and after omeprazole. Gastroenterology 1991;100:1563-70.

27 Tielemans $Y$, Axelson J, Sundler $F$ et al. Serum gastrin concentration affects the self replication rate of the enterochromaffin-like celis in the rat stomach. Gut 1990;31:274-8.

28 Creutzfeldt $\mathrm{W}$, Lamberts $\mathrm{R}$ et al. Inter-relationship between serum gastrin levels, gastric mucosal histology and gastric endocrine cell growth. Digestion 1992;51(Suppl 1):76-81.

29 Lamberts $\mathrm{R}$, Creutzfeldt $\mathrm{W}$, Struber $\mathrm{H}$ et al. Longterm omeprazole therapy in peptic ulcer disease: gastrin, endocrine cell growth and gastritis. Gastroenterology 1993;104:1356-70.

30 Solcia E, Fiocca $R$, Havu $\mathrm{N}$ et al. Gastric endocrine cells and gastrin in patients receiving long-term omeprazole treatment. Digestion 1992;51 (Suppl 1):82-92.

31 Hakanson $R$, Chen $D$, Tielemans $Y$ et al. ECL cells: biology and pathobiology. Digestion 1994:55 (Suppl 3):38-45. 
32 Hakanson $\mathbb{R}$, Sundler $\mathbb{P}$. Proposed mechanism of induction of gastric carcinoids: The gastrin hypothesis. Eur J Clin Invest 1990;20(Suppl 1):65-71.

33 Creutzfeldt $W$. The achlorhydria-carcinoid sequence: Role of gastrin. Digestion $1988,39: 61-79$.

34 Modlin $\mathbb{I}$, Tang $\mathrm{L}$. The gastric enterochromaffin-like cell: an enigmatic cellular link. Gastroenterology 1996,111:783-810.

35 Havu. N. Enterochromaffin-like cell carcinoids of gastric mucosa in rats after lifelong inhibition of gastric secretion. Digestion 1986;35:42-55.

36 Havu N, Mattson H, Ekman L, Carlsson E. Enterochromaffin cell carcinoids in rat gastric mucosa following long-term administration of ranitidine. Digestion $1990 ; 45: 189-95$.

37 Borch $\mathrm{K}$, Renvall $\mathrm{H}$, Liedberg $\mathrm{G}$. Gastric endocrine cell hyperplasia and carcinoid tumours in pernicious anemia. Gastroenterology $1985 ; 88: 638-48$.

38 Solcia E, Capella C, Fiocca $R$ et al. Gastric argyrophil carcinoidosis in patients with Zollinger-Elllison syndrome due to type $\mathbb{I}$ multiple endocrine neoplasia. A newly recognized association. Am J Surg Pathol 1990;14:503-13.

39 Rode J, Dhillon A, Papadaki L et al. Pernicious anaemia and mucosal endocrine cell proliferation of the non- antral stomach. Gut 1986;27:789-98.

40 Waldum $H$, Haugen $O$, Isaksen $R$ et al. Enterochromaffin-like cells in the diffuse but not the intestinal type of gastric carcinomas. Scand J Gastroenterol 1991;26 (Suppl 180):165-9.

41 Waldum H, Brenna E, Kleveland P, Sandvik A. Gastrin-physiological and pathophysiological role: clinical consequences. Dig Dis 1995;13:25-38.

42 Lamberts R, Creutzfeldt W, Stockmann F et all. Long-term omeprazole treatment in man: effects on gastric endocrine cell populations. Digestion 1988;39:126-35.

43 Klinkenberg-Knol E, Festen H, Jansen J et al. Long-term treatment with omeprazole for refractory reflux esophagitis: efficacy and safety. Annals of Internal Medicine $1994 ; 121: 161-167$.

44 Stabile B, Howard T, Pasaro E, O'Conner D. Source of plasma chromogranin A elevation in gastrinoma patients. Arch Surg 1990;125:451-3.

45 Grube D, Bargsteb $G$, Cetin $Y$, Yoshie S. Chromogranins in mammmalian GEP endocrine cells: their distribution and interrelations with co-stored amines and peptides. Arch Histol Cytol 1989;52:91-8.

46 Waldum H, Amestad $\mathrm{E}$; Brenna I et al. Marked increase in gastric acid secretory capacity after omeprazole treatment. Gastroenterology 1996;108:A991.

47 Smith J, Kramer S, Demers I. Effects of gastrin and difluoromethylornithine on growth of human colon cancer. Dig Dis Sci 1993;38:520-8. 


\section{Chapter VII}

Helicobacter pylori and nonHelicobacter pylori intragastric bacterial flora in patients with intestinal and diffuse type of gastric adenocarcinoma

G Houben, D Jonkers, A de Bruine, E Stobberingh, R Stockbrügger 


\section{Introduction}

Recently increasing evidence is found for a role of Helicobacter pylori (H.pylori) in gastric carcinogenesis. Histological studies find $H$.pylori-prevalences in $43 \%$ $78 \%$ of gastric cancer patients ${ }^{1-3}$ and in retrospective serological studies, Odds ratios have been found between 2.8 and 6.0 for an increased risk of gastric cancer in H.pylori positive subjects.

Two types of gastric cancer can be distinguished according to the classification by Lauré $n^{5}$ : the well-differentiated or intestinal type and the undifferentiated or diffuse type of gastric adenocarcinoma. Although in some studies H.pylori seemed to be mainly associated with the intestinal type of gastric cancer ${ }^{2.6,7}$, recently several studies find similar prevalences of $H$.pylori in both diffuse and intestinal type carcinoma ${ }^{8-10}$.

H.pylori associated chronic gastritis could form the common basis for both gastric cancer types ${ }^{11,12}$, but subsequently different pathophysiological pathways may arise from chronic gastritis. In the intestinal type of gastric cancer, the histological sequence of H.pylori associated gastritis towards atrophic gastritis and intestinal metaplasia will play a role. The diffuse type may arise more directly from hyperplastic or atypical necks of gastric glands through primary involvement of genes affecting cell to cell and cell to matrix junctional proteins ${ }^{12,13}$. Waldum ${ }^{14}$ has found ECL-cell derived tumours to be present in $40 \%$ of diffuse type gastric carcinoma but not in the intestinal type. ECL cell hyperplasia and subsequent carcinoid formation can result from hypergastrinaemia ${ }^{15,16}$.

The onset of either of these two pathways leading to an intestinal or diffuse type gastric cancer, may be influenced by the duration of H.pylori infection, by the previous or present distribution and density of H.pylori, and also by strain differences. However, host and/or environmental factors may play a role, either alone or in combination with H.pylori ${ }^{17-19}$. One such host factor may be the gastric colonization with other bacteria, the non-H.pylori flora, known to be present in the hypochlorhydric and achlorhydric stomach ${ }^{20.23}$. Part of the intragastric non-H.pylori flora is able to reduce nitrate to nitrite; nitrite can form potentially carcinogenic N-nitroso compounds ${ }^{24-26}$.

Bacterial overgrowth is found in gastric cancer precursor lesions and conditions such as atrophic gastritis ${ }^{21}$ and pernicious anaemia ${ }^{27.28}$. Thus, in the sequence towards gastric cancer, both H.pylori and non-H.pylori bacterial flora may play a 
role.

In the present study the bacterial gastric flora, H.pylori and non-H.pylori, was assessed in gastric cancer patients and related to the type and site of the tumour.

\section{Patients and methods}

\section{Patients}

Patients $(n=82)$ with obvious or suspicious gastric cancer who attended the endoscopic department of the University Hospital Maastricht between January 1992 and December 1994 were included in the study.

\section{Endoscopy}

During endoscopy, the basal gastric juice $\mathrm{pH}$ was measured using $\mathrm{pH}$-paper strips with grading steps of 0.5 from $\mathrm{pH} 0$ to $\mathrm{pH} 14$ (Schleicher \& Schüll GmbH; Dassel, Germany). Biopsies from corpus, antrum and duodenal mucosa and from the tumour were obtained during gastroscopy and fixed in formalin.

\section{Histology}

Specimens were embedded in paraffin and serial sections were cut for Haematoxylin-Eosin stain (HE), modified Giemsa stain $(\mathrm{MG})^{29}$, and Immunohistochemistry (IMM) ${ }^{30}$.

HE stained sections were used for the microscopic confirmation of the tumour and the assessment of the tumour type according to the classification by Laurén ${ }^{5}$. IMM, using a purified polyclonal antiserum against H.pylori (DAKO B471, ITK diagnostics BV, Uithoorn, The Netherlands), was applied for the specific detection of H.pylori. Using the MG stain, the intragastric bacterial flora, i.e. H.pylori and non-H.pylori bacterial flora, was assessed according to form and location. Presence of non-H.pylori flora was confirmed by a negative IMM stain on the same position of consecutive sections.

At least two cross-sections of all biopsies were examined completely at $400 \mathrm{x}$ magnification. If necessary a $1000 \mathrm{x}$ magnification was used. The presence of H.pylori and of non-H.pylori flora was graded semi-quantitatively (grade $0,1,2,3$ ): no bacteria found (grade 0); occasionally bacteria seen after searching (grade 1); scattered bacteria found in many fields (grade 2); numerous bacteria found in many 
fields (grade 3$)^{31}$.

\section{Culture}

From a selected group of 32 out of the 82 patients, additional biopsies and/or gastric juice were obtained for culture.

Gastric juice was homogenized, and 1,10 , and $100 \mu \rrbracket$ were inoculated on blood agar plates (Oxoid CM 271, Basingstoke, England, with 5\% sheep blood) for total aerobic growth and on CLED agar plates (Oxoid CM423) for enhanced detection of Enterobacteriaceae, using the five segments method ${ }^{32}$.

Biopsies were washed thrice in sterile saline to remove contaminating flora, thereafter transferred to the agar plates with a sterile forceps and inoculated as described above. Agar plates were incubated at $37{ }^{\circ} \mathrm{C}$ for two days and colonies were identified according to standard microbiological methods ${ }^{33}$.

\section{Analyses}

The prevalence of $H$.pylori and non- $H$.pylori in corpus, antrum, duodemum and tumour, as well as the prevalence of $H$.pylori or non-H.pylori in relation to gender, tumour type and tumour site were analyzed with a Chi-square test between patient groups and with a McNemar test within patient groups. Intragastric $\mathrm{pH}$ and age of (nom-) H.pylori positive and negative patients and relations with density of H.pylori or non-H.pylori were compared with the Mann-Whitney $U$ test or the KruskallWallis test depending on the number of groups to be compared. Within groups, the density of H.pylori and non-H.pylori flora was compared with the Wilcoxon signed ranks test.

A P-value of less than 0.05 was considered to be significant.

\section{Results}

Eighty-two patients with gastric cancer suspected at endoscopy, and hence confirmed by microscopy could be analyzed. The group consisted of 49 males and 33 females with a median age of 73.5 years (range 45-93).

Basal fasting $\mathrm{pH}$ of gastric juice was measured in 49 patients and showed a median $\mathrm{pH}$ of 6.0 (range $1.0-8.0$ ). The intragastric $\mathrm{pH}$ was above 3.5 in 36 of 49 patients (73.5\%). 
Sixty-two patients had an intestinal type and 20 patients a diffuse type of gastric cancer. The tumour was located in antrum of 28 , in corpus of 41 , in both antrum and corpus of eight patients and one and four patients, respectively, had a Billroht 1 and Billroth II operated stomach. No significant association was found between the histological type and the site of the tumour.

\section{Presence of H.pylori and non-H.pylori on histology}

Corpus, antrum, duodenum and tumour tissue were available from $56,65,45$, and 75 patients, respectively. At least two biopsies were analyzed per histological site except in four patients in whom just one biopsy was available from duodenum (one patient), corpus (two patients), or antrum (one patient).

Taking the findings from all anatomical sites together, H.pylori was detected by IMM in 38 of 82 patients ( $46.3 \%$ ). Non-H.pylori bacterial flora was found in 58 of 82 patients $(70.7 \%)$. H.pylori only was found in $11(13.4 \%)$, non-H.pylori only in $31(37.8 \%)$, both types of flora in $27(32.9 \%)$ and in 13 patients $(15.9 \%)$ no bacterial flora at all was detected using histology (Figure VII.1).

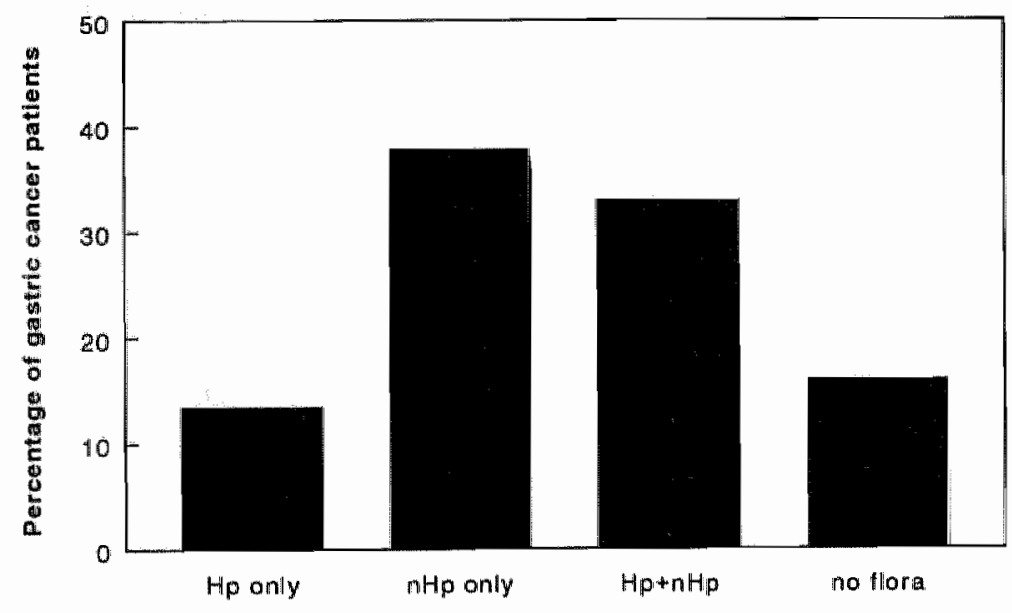

Figure VII.1: Percentage of gastric cancer patients with presence of H.pylori and non-H.Pylari on histology 
The prevalence of H.pylori and non-H.pylori bacterial flora was scored in corpus, antrum, duodenum and tumour tissue (Table VII.1).

H.pylori was not detected in tumour tissue and in only one duodenal biopsy. The prevalence of $H$.pylori was significantly higher in corpus than antrum mucosa $(\mathrm{P}<0.05)$. In contrast, non-H.pylori flora was found with a similar frequency in corpus, antrum, duodenum and tumour tissue. No differences were found in the prevalence of H.pylori compared with non-H.pylori bacterial flora in antral or corpus biopsies.

Table VII.1: $\quad$ Prevallence of $H$ pylori and non- $H$ pyloni bacterial flora in patient with gastric cancer $(\mathrm{n}=82$ ) according to the histological sites

\begin{tabular}{|c|c|c|c|c|c|}
\hline \multicolumn{2}{|c|}{ Histological site } & \multicolumn{2}{|c|}{ H.pylari (IMM) } & \multicolumn{2}{|c|}{ non-H.pylon (MG) } \\
\hline & $\mathbf{n}$ & $\mathbf{n}$ & (\%) & a & $(\%)$ \\
\hline corpus & 56 & 33 & $(58.9 \%)^{\prime}$ & 32 & $(57.1 \%)$ \\
\hline antrum & 65 & 22 & $(33.8 \%)^{1}$ & 36 & $(55.4 \%)$ \\
\hline diuodenum & 45 & 1 & $(2.2 \%)$ & 20 & $(44.4 \%)$ \\
\hline tumour & 75 & - & $(0.0 \%)$ & 44 & $(58.7 \%)$ \\
\hline
\end{tabular}

${ }^{1}$ Higher H.pylori prevalence in corpus than antrum mucosa: $\mathrm{P}<0.05$

No differences were found in the bacterial density of biopsies positive for either H.pylori or non-H.pylori flora in antrum compared with corpus (Figure VII.2). But a significantly higher density of non-H.pylori flora was found in tumour tissue compared with both corpus $(\mathrm{P}<0.05)$ and antrum $(\mathrm{P}=0.05)$.

No statistical differences were found according to gender, $\mathrm{pH}$, tumour type and tumour site between H.pylori positive and negative patients or between nonH.pylori positive and negative patients. However, H.pylori positive patients (median age : 70.5 (51-90) years) were significantly younger than H.pylori negative ones (median age: $79(45-89)$ years) $(\mathrm{P}<0.05)$. No significant differences were found between non-H.pylori positive (median age: 72.5 (51-93) years) and nonH.pylori negative patients (median age: 78.5 (45-89) years). 


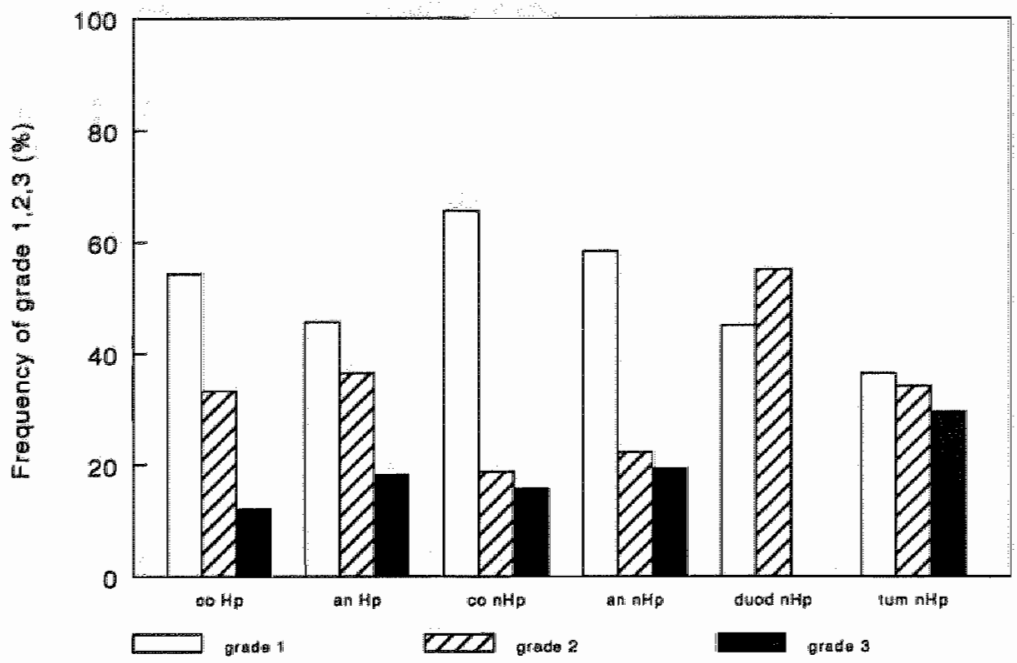

Figure VII.2: Density of the bacterial flora in percentages in antrum, corpus, duodenum and tumour

Patients with H.pylori only, non-H.pylori only, both or no bacterial flora

Patient characteristics according to the presence of H.pylori only, non-H.pylori only, both or no bacterial flora found, are given in Table VII.2.

In patients with both H.pylori and non-H.pylori, the prevalence of H.pylori was significantly higher in corpus than in antrum mucosa $(\mathrm{P}<0.01)$. No further differences were found comparing H.pylori and non-H.pylori over the different histological sites between the four patient groups. 
Table VII.2: Patient characteristics and gastroduodenal distribution of H.pylori (Hp) and non-

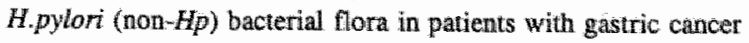

\begin{tabular}{|c|c|c|c|c|}
\hline & $\begin{array}{l}\text { Hp only } \\
n=11\end{array}$ & $\begin{array}{l}\text { non-Hp only } \\
n=30\end{array}$ & $\begin{array}{l}\text { both Hp/non-Hp } \\
\mathrm{n}=28\end{array}$ & $\begin{array}{l}\text { no bact Mora } \\
\mathrm{n}=13\end{array}$ \\
\hline Gender & $4 / 7$ & $19 / 11$ & 1711 & $9 / 4$ \\
\hline Age & $66 \quad(54-89)$ & $77.5 \quad(52-93)^{8}$ & $71 \quad(51-90)^{t}$ & $80 \quad(45-84)$ \\
\hline $\mathrm{pH}$ & $6.0(5.5-7.0)$ & $6.5 \quad(1.0-8.0)$ & $6.0 \quad(0.5-8.0)$ & $5.5(1.5-7.0)$ \\
\hline \multicolumn{5}{|l|}{ Tumour type } \\
\hline -intestinal & $63.6 \%$ & $83.3 \%$ & $71.4 \%$ & 76.9 \% \\
\hline - diffuse & $36.4 \%$ & $16.7 \%$ & $28.6 \%$ & $23.1 \%$ \\
\hline \multicolumn{5}{|l|}{ Tumour site } \\
\hline - corpus & $63.6 \%$ & $43.3 \%$ & $50.0 \%$ & 53.8 器 \\
\hline - antrum & $18.2 \%$ & $33.3 \%$ & $42.9 \%$ & $30.8 \%$ \\
\hline - corpus/antrum & $9.1 \%$ & $13.3 \%$ & $7.1 \%$ & $7.7 \%$ \\
\hline - Billroth I & $0.0 \%$ & $3.3 \%$ & $0.0 \%$ & $0.0 \%$ \\
\hline - Billroth III & $9.1 \%$ & $6.7 \%$ & $0.0 \%$ & $7.7 \%$ \\
\hline \multicolumn{5}{|l|}{ H.pylari } \\
\hline - corpus & $100 \%^{2}$ & - & $100 \%^{3}$ & . \\
\hline - antrum & $85.7 \%^{2}$ & . & $59.3 \%^{3}$ & - \\
\hline - duodenum & $16.7 \%$ & - & $0.0 \%$ & - \\
\hline \multicolumn{5}{|l|}{ non-H.pylori } \\
\hline - corpus & - & $87.5 \%$ & $78.3 \%$ & - \\
\hline antrum & - & $72.7 \%$ & $74.1 \%$ & - \\
\hline - duodenum & - & $68.8 \%$ & $50.0 \%$ & - \\
\hline - tumour & - & $85.7 \%$ & $80.0 \%$ & . \\
\hline
\end{tabular}

${ }^{1}$ Patients with non-Hp only were older than patients with both $\mathrm{Hp}$ and non-Hp: $\mathrm{P}=0.07 ;{ }^{2}$ Hp densities in corpus and antrum were higher in patients with $\mathrm{Hp}$ only than in patients with both floras: corpus $\mathrm{P}=0.07$. antrum $\mathrm{P}=0.08 ;$; Higher prevalences of $\mathrm{Hp}$ in corpus than antrum of patients with both floras: $\mathrm{P}<0.01$

The density of H.pylori in corpus $(\mathrm{P}=0.07)$ and antrum $(\mathrm{P}=0.08)$ tended to be higher in the patients with H.pylori only compared to the patients with both H.pylori and non-H.pylori. No further differences in H.pylori or non-H.pylori densities were found between the four subgroups (Figure VII.3a-VII.3c).

Between the four patient-groups, no differences were found in gender, age, $\mathrm{pH}$, tumour type and tumour site. Only a tendency was present towards a higher age of patients with non-H.pylori flora only versus those with both types of flora $(\mathrm{P}=0.07)$. 


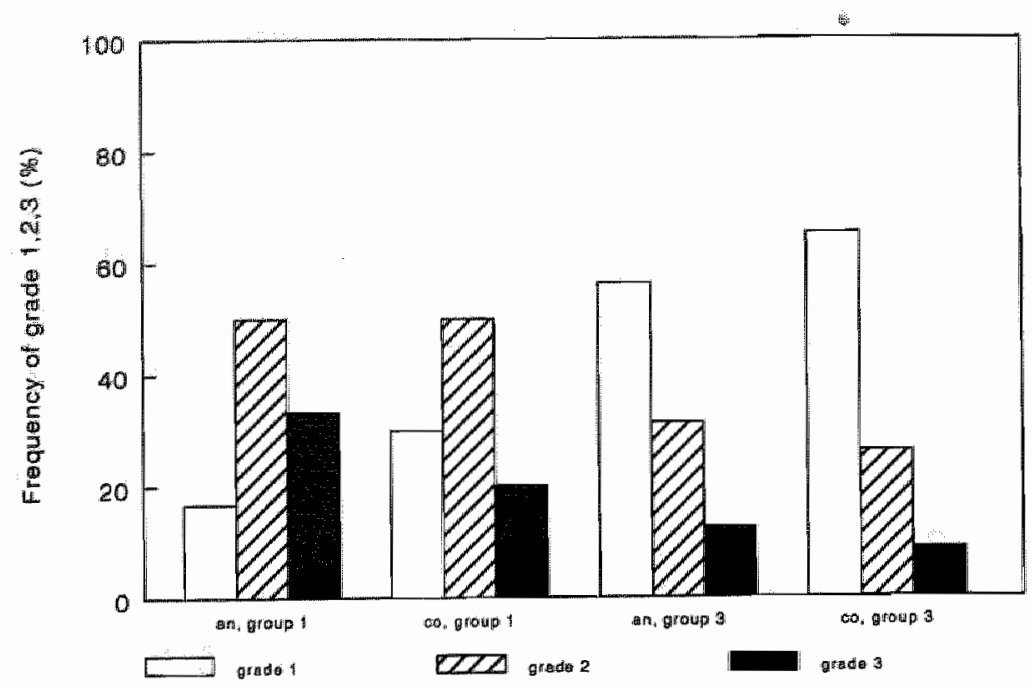

Figure VII 3a: Density of H.pylori in percentages in antrum and corpus, in patients with $H$.pylori only (group 1) and in patients with H.pylori and non-H.pylori (group 3)

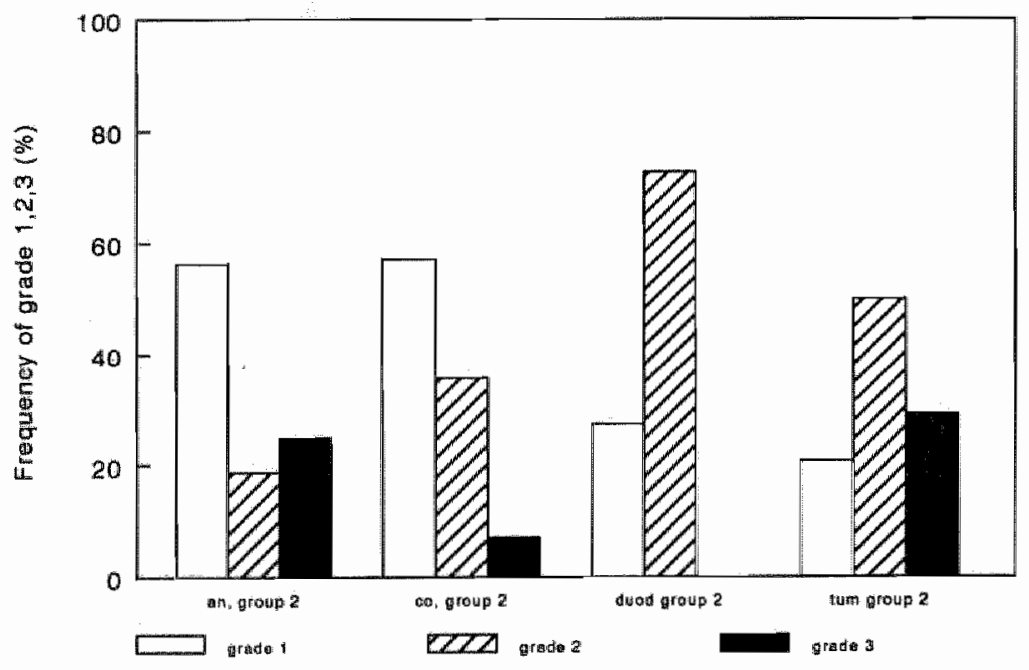

Figure VII.3b: Density of non-H pylori in percentages in antrum, corpus, duodenum and tumour in patients with non-H.pylori flora only" 


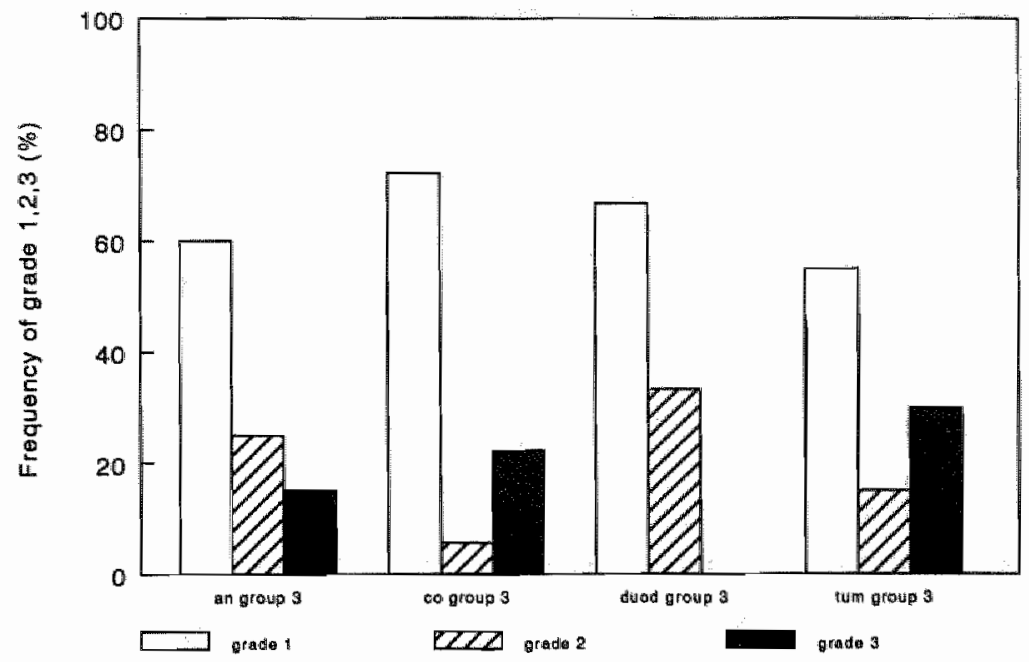

Figure VII.3c: Density of non-H.pylori in percentages in antrum and corpus, duodenum and tumour in patients with $H$.pylori and non-H.pylori

\section{Non-H.pylori bacterial flora detected by histology}

Using histology, non-H.pylori flora was detected in 58 patients. In seven of these, it was only found in tumour tissue and in one patient it was only found in the duodenal bulb biopsy. In the remaining 50 patients non- $H$.pylori flora was present in antrum and/or corpus mucosa.

In 24 patients, the histologically detected non- $H$.pylori flora comprised cocci only. In 12 patients similar amounts of cocci and rods were found, and in 13 patients mainly cocci with minor amounts of rods were present. In another two and eight patients, respectively, only rods or mainly rods with some cocci were found.

In most of the 50 patients with non- $H . p y l o r i$ flora found in non-tumorous tissue, this was localized superficially (in strains of mucus overlying the mucosa). However, in 17 and 10 of these patients, the non-H.pylori flora was also found, to a similar or minor degree, in the mucus layer of the superficial glands. In tumour tissue, the non-H.pylori flora was mainly localized on the surface of the tumour, but in a quarter of the specimens it was also found within the superficial layer of the tumour.

Yeast and (pseudo)mycelium threads were seen in 13 and 12 patients, respectively, 
with a median density of grade one and two. Both were mainly localized on the surface of the tumour tissue.

\section{Non-H.pylori flora cultured from gastric biopsies and from gastric juice}

In 22 of 32 gastric cancer patients with culture results available $(68.8 \%)$, oropharyngeal flora and/or Enterobacteriaceae were detected in gastric juice and/or biopsies. In 5 of 22 patients only gastric juice was positive by culture; in three of them biopsies were not taken. In the remaining 17 of 22 patients, biopsies were culture positive.

Oropharyngeal flora and Enterobacteriaceae were found with a relatively high frequency in gastric juice and to a minor extent, also in the biopsies (Table VII.3). Oropharyngeal flora only was found in eleven patients, Enterobacteriaceae only in five patients, and both oropharyngeal flora and Enterobacteriaceae in six patients. Oropharyngeal flora included Neisseria spp., Streptococci spp., and Corynebacterium spp. Concerning the Enterobacteriaceae, either one or a combination of two or three species were found: Escherichia coli, Klebsiella spp., Proteus spp. were cultured seven, five, and two times, respectively. In addition, once Citrobacter freundii, Enterobacter cloacae or Favobacterium spp. were cultured.

Table VII.3: $\quad$ Presence of oropharyngeal and faecal like flora by culture in patient with gastric carcer $(\mathrm{n}=32)$

\begin{tabular}{lllll}
\hline Hist. site & & $\begin{array}{l}\text { oropharyngeal } \\
\text { flora }\end{array}$ & $\begin{array}{l}\text { faccal-like } \\
\text { flora } \\
\mathbf{n}(\%)\end{array}$ & $\begin{array}{l}\text { notal } \\
\text { nora }\end{array}$ \\
\hline corpus & $\mathbf{n}$ & $5(31.1)$ & $2(12.5)$ & $\mathbf{n}(\%)$ \\
antrum & 16 & $13(44.8)$ & $5(17.2)$ & $7(43.8)$ \\
duodenum & 29 & $10(40.0)$ & $4(16.0)$ & $17(58.6)$ \\
g.juice & 25 & $11(61.1)$ & $7(38.9)$ & $13(52.0)$ \\
\hline
\end{tabular}

In 15 patients culture was positive in biopsies and in gastric juice. In 12 of 15 patients concordance was found between the bacterial flora detected in gastric juice and in the biopsies. 
A significant higher intragastric $\mathrm{pH}$ was found in patients with positive culture results for non-H.pylori flora (median $\mathrm{pH} 7.0(1.5-8.0)$ ) compared to those with negative culture results (median pH $2.0(1.07 .0))(\mathrm{P}<0.01)$.

\section{H.pylori and non-H.pylori flora according to tumour type and tumour site}

The characteristics of the patients with an intestinal or diffuse type of gastric cancer and prevalence of H.pylori and non-H.pylori flora are given in Table VII.4. Significantly more males were present in the patient group with the intestinal type of cancer compared with the diffuse type $(P<0.01)$, and patients with the diffuse type were significantly younger than patients with the intestinal type $(\mathrm{P}<0.01)$.

Comparing patients according to the location of their tumour in antrum or corpus, no differences were found in age and gender (Table VII.4). The basal intragastric $\mathrm{pH}$ tended to be higher when the tumour was located in the corpus compared to antral location $(\mathrm{P}=0.06)$. However, the prevalence of non- $\mathrm{H}$.pylori flora tended to be higher in antrum and duodenum as well as in corpus when the tumour was located in antrum or corpus, respectively. However, none of the differences were statistically significant.

Table VII.4: Gender, age and intragastric pH of gastric cancer patients according to numour type and tumour site

\begin{tabular}{|c|c|c|c|c|}
\hline & & $\begin{array}{l}\text { Gender } \\
\text { male/female }\end{array}$ & $\begin{array}{l}\text { Age } \\
\text { median (range) }\end{array}$ & $\begin{array}{l}\text { pH } \\
\text { median (range) }\end{array}$ \\
\hline \multicolumn{5}{|c|}{ Tumour type } \\
\hline intestinal & $n=62$ & $42 / 20^{!}$ & $77(48-93)^{2}$ & $6.0(1.0-8.0)$ \\
\hline diffuse & $n=20$ & $7 / 13^{1}$ & $67(45-90)^{2}$ & $6.0(1.5-7.0)$ \\
\hline \multicolumn{5}{|c|}{ Tumour site } \\
\hline antrum & $\mathrm{n}=28$ & $20 / 8$ & $73.5(51-85)$ & $5.0(1.5-8.0)^{3}$ \\
\hline corpus & $\mathrm{n}=41$ & $22 / 19$ & $71.0(45-93)$ & $7.0(1.0-7.0)^{3}$ \\
\hline
\end{tabular}

'More males were present in the intestinal than the diffuse type: $P<0.01$;

${ }^{2}$ Patients with the diffuse type were younger than those with the intestinal type: $P<0.01 ;{ }^{3}$ The intragastric $\mathrm{pH}$ tended to be higher when the tumour was located in the corpus compared with the antrum: $\mathrm{P}=0.06$

\section{Discussion}

H.pylori and non-H.pylori bacterial flora were found in $46.3 \%$ and $70.7 \%$, respectively, in a consecutive series of gastric cancer patients, with a similar 
prevalence and distribution in both intestinal and diffuse type carcinomas irrespective of the tumour location.

In the present study a lower prevalence of H.pylori was found compared to findings in the literature: prevalences ranging from $59 \%-78 \%$ were described by others ${ }^{1-3.6,9}$ using a $\mathrm{HE}$ stain and/or a MG stain. The difference in $H$.pylori flora is very likely to be due to our use of a specific immunohistochemical stain for the specific detection of H.pylori. The use of non-specific histological stains by others, may result in false positive cases when high amounts of non-H.pylori flora are present ${ }^{34}$. In serological studies higher $H$.pylori prevalences were found ranging from $52 \%$ $94 \%^{2,4,35-37}$. These prevalences may differ from histological findings because positive serology does not differentiate between a previous and current infection.

We do not find a major difference between the H.pylori prevalence in gastric cancer patients compared to the prevalence in healthy subjects of the similar age and the same geographical area detected by serology ${ }^{1}$ or in a group of patients undergoing upper endoscopy and H.pylori detected by positive culture or HE stain combined with the biopsy urease test. Also Kuipers ${ }^{38}$ and Webb ${ }^{39}$ cannot support that H.pylori is associated with an increased risk of gastric cancer.

The prevalence of H.pylori was higher in corpus than antrum mucosa of both patients with intestinal and diffuse type of gastric cancer independent of the tumour site. This finding is in line with the high intragastric $\mathrm{pH}$ found in most of the gastric cancer patients, as migration of H.pylori from antrum towards corpus mucosa is known to occur in hypochlorhydric or achlorhydric patients ${ }^{40-42}$.

A high intragastric $\mathrm{pH}$ and higher $H$.pylori densities in corpus than antrum mucosa are also found in gastric ulcer patients in comparison with duodenal ulcer patients ${ }^{43}$.

Furthermore, H.pylori positive gastric cancer patients were significantly younger than patients without H.pylori, as described by others ${ }^{37,44}$. Acquisition of H.pylori at young age might be associated with an increased risk for gastric ulcer but not for duodenal ulcer ${ }^{45,46}$. These similarities between gastric cancer and gastric ulcer patients support the finding of Hansson ${ }^{46}$, that the gastric ulcer patients are at higher risk to develop gastric cancer in comparison with duodenal ulcer patients.

No differences were found in the gastroduodenal distribution of H.pylori between patients with an intestinal versus a diffuse type of gastric cancer or according to the 
turnour site.

Although H.pylori may play an initial role in both types of cancer, other factors seem to be involved in the final development of the two gastric cancer types. In this study, relatively high amounts of non- $H$.pylori flora were supported by culture results. Similar prevalences of the non-H.pylori flora in corpus, antrum, duodenum and tumour tissue suggest that this flora is a consequence of the reduced acid secretion found in the stomach. But the higher density in the tumour tissue compared with the non-tumorous tissue suggests that also a reduced motility and stagnant loop situation by the tumour mass may play a role. However, the position of the non-H.pylori bacteria in the crypts and the positive cultures from carefully washed biopsies suggest that the non-H.pylori flora found is not just a result of contamination.

Major differences in non-H.pylori prevalences or densities are not found between intestinal versus diffuse type gastric cancer patients and are therefore not expected to play a role in the phenotypic development of either the intestinal or the diffuse type of gastric cancer.

The relatively low presence of H.pylori and the presence of the non-H.pylori flora will not necessarily reflect the situation during the initial stages of gastric carcinogenesis in the single patient. Although we cannot exclude from this study that non-H.pylori flora is just a consequence of the histological changes, it can be expected that this flora is also present in gastric cancer precursor stages with reduced gastric acidity, such as atrophic gastritis. Thereby, the non-H.pylori flora may contribute to the progression of gastric cancer by acting as an antigenic trigger or by the production of toxic or carcinogenic metabolites, such as $\mathrm{N}$-nitroso compounds ${ }^{24.26}$.

The time course from the initial events in the cascade until gastric cancer development will last at least 20 years. The increase in age with the type of intragastric bacteria present, from H.pylori only, to both H.pylori and non-H.pylori and finally non-H.pylori only, suggests that H.pylori may play an initial role leading to histological changes such as atrophic gastritis and intestinal metaplasia. Thereby the $\mathrm{pH}$ increases and non-H.pylori flora may also colonize the gastric mucosa. When the environment is too hostile, H.pylori colonization will decrease. Findings of positive serology and negative histology for H.pylori, supports an initial role of $H$.pylori in gastric cancer patients.

Independent of the role of the non-H.pylori flora found, it will confound the 
detection of H.pylori by histology or by culture.

In conclusion, a current H.pylori infection cannot be demonstrated in 44 of 82 gastric cancer patients but a relatively high frequency of non-H.pylori flora is found. Whether this flora is just a consequence of histological changes or can contribute to gastric carcinogenesis needs further study. 


\section{References}

1 Loffeld $\mathrm{R}$, Willems $\mathrm{I}_{*}$ Flendrig $\mathrm{J}$, Arends $\mathrm{J}$. Helicobacter pylori and gastric carcinoma. Histopathol 1990;17:537-541.

2. Parsonnet J, Vandersteen D, Goates J et al. Hellicobacter pylon infection in intestinal- and diffuse-type gastric adenocarcinomas. I Natl cancer Inst $1991 ; 83: 640-643$.

3 Fiocca F, Luinetti $O$, Villani $L$ et al. High incidence of Helicobacter pylori colonization in early gastric cancer and the possible relationship to gastric carcinogenesis. 1993

4 Forman D, Newell D, Fullerton $F$ et al. Association between infection with Helicobacter pylori and risk of gastric cancer: evidence from a prospective investigation. Br Med J 1991;302:1302-1305.

5 Laurén P. The two histological main types of gastric carcinoma: diffuse and socalled intestinal-type carcinoma. Acta Pathol Microbiol Scand 1965;64:31-49.

6 Buruk F, Berberoglu U, Pak I et al. Gastric cancer and Helicobacter pylori infection. Br J Surg 1993;80:378-379.

7 Nogueira A, Ribeiro G, Rodriguez M et al. Prevalence of Helicobacter pylori in Brazilian patients with gastric carcinoma. Am J Clin Pathol 1993;100:236-239.

8 Sipponen $\mathrm{P}$, Kosunen $\mathrm{T}$, Valle $\mathrm{J}$ et al. Helicobacter pylori infection and chronic gastritis in gastric cancer. J CLin Pathol 1992;45:319-323.

9 Wee A, Kang J, Teh M. Helicobacter pylori and gastric cancer: correlation with gastritis, intestinal metaplasia, and tumour histology. Gut 1992;33:1029-1032.

10 Hansson L, Engstrand L, Nyrén O, Lindgren A. Prevalence of Helicobacter pylori infection in subtypes of gastric cancer. Gastroenteroll 1995;109:885-888.

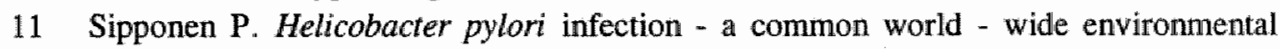
risk factor for gastric cancer? Endoscopy 1992;24:424-427.

12 Solcia E, Fiocca $R$, Luinetti $O$ et al. Intestinal and diffuse gastric cancers arise in a different background of Helicobacter pylori gastritis through different gene involvement. Am J Surg Pathol 1996;20(Suppl 1):S8-S22.

13 Fenoglio-Preiser C, Noffsinger A, Belli $I$, Stemmermann N. Pathologic and phenotypic features of gastric cancer. Sem Oncol 1996;23:292-306.

14 Waldum $H$, Haugen $O$, Isaksen $C$ et al. Enterochromaffin-like tumour cells in the diffuse but not the intestinal type of gastric carcinoma. Scand J Gastroenterol $1991: 26$ (Suppl 180):165-169.

15 Waldum $\mathrm{H}$, Brenna E, Kleveland P, Sandvik A. Gastrin - Physiological and pathophysiological role: Clinical consequences. Dig Dis 1995;13:25-38.

16 Öberg K. Neuroendocrine gastrointestinal tumours. Review. Ann Oncol 1996;7:453-463.

17 Fuchs C, Mayer R. Review article: Gastric carcinoma. N Engl J Med $1995 ; 333: 32-41$. 
18 Neugut A, Hayek M, Howe G. Epidemiology of gastric cancer. Sem Oncol 1996:23:281-291.

19 Houben G, Stockbrüger R. Bacteria in the aetio-pathogenesis of gastric cancer; a review. Scand J Gastroenterol 1995;30:Suppl 212:13-18.

20 Gray J; Shiner $M$. Influence of gastric $\mathrm{pH}$ on gastric and jejunal flora. Gut $1967 ; 8: 574-581$.

21 Drasar B, Shiner M, McLeod G. Studies on the intestinal flora. I. The bacterial flora of the gastrointestinal tract in healthy and achlorhydric persons. Gastroenterol 1969;56:71-79.

22 Hunt R. The protective role of gastric acid. Scand J Gastroenterol 1988;23 (Suppl 146):34-39.

23 Wilder-Smith $\mathrm{C}$, Spirig $\mathrm{C}$, Krech $\mathrm{T}$, Merki $\mathrm{H}$. Bactericidal factors in gastric juice. Eur J Gastroenterol Hepatol 1992;4:885-891.

24 Ruddell $\mathrm{W}$, Bone $\mathrm{E}$, Hill $\mathrm{M}$ et al. Gastric juice nitrate: a risk factor for cancer in the hypochlorhydric stomach? Lancet 1976; ii: 1037-1039.

25 Stockbrügger $\mathrm{R}$, Cotton $\mathrm{P}$, Eugenides $\mathrm{N}$ et al. Intragastric nitrites, nitrosamines and bacterial overgrowth during cimetidine treatment. Gut 1982;23:1048-1054.

26 Forsythe S, Dolbey J, Webster A, Cole J. Nitrate- and nitrite-reducing bacteria in the achlorhydric stomach. J Med Microbiol 1988;25:253-259.

27 Dolby J, Webster A, Boriello S et al. Bacterial colonization and nitrite concentration in the achlorhydric stomach of patients with primary hypogammaglobulinaemia or classical pernicious anaemia. Scand J Gastroenterol 1984;19:105-110.

28 Stockbrügger $\mathrm{R}$, Cotton $\mathrm{P}$, Menon $\mathrm{G}$ et al. Pernicious anaemia, intragastric bacterial overgrowth, and possible consequences. Scand J Gastroenterol 1984;19:355-364.

29 Gray S, Wyatt J, Rathbone B. Simplified techniques for identifying Campylobacter pyloridis. J Clin Pathol 1986;39:1279.

30 Jonkers D, Houben G, Stobberingh E, Stockbrügger R. Ongoing gastric acid inhibition is a confounding factor in Helicobacter pylori diagnosis. Eur $\mathrm{J}$ Gastroenterol Hepatol 1996;9:1-5.

31 Marshall B, Warren J. Unidentified curved bacilli in the stomach of patients with gastritis and peptic ulceration. Lancet 1984;i:1311-1315.

32 Cruickshank R, Duguid J, Marmion B, Swain R. Medical Microbiology, 12th edition, volume II. Churchill Livingstone, Edinburgh, 1975.

33 Balows A, Hausler W, Herrmann $\mathrm{K}$ et al. Manual of Clinical Microbiology, 5th edition. Washington DC, American Society for Microbiology; 1991

34 Jonkers $D$, Houben $G$, de Bruine $A$ et al. The gastroduodenal distribution of Helicobacter pylori in patients with duodenal and gastric ulcer: relation to inflammatory changes, mucosal atrophy, and intestestinal metaplasia in the stomach and gastric metaplasia in the duodenum (Submitted).

35 Talley N, Zinsmeister A, Weaver A et al. Gastric adenocarcinoma and Helicobacter pylori infection. J Natl Cancer Inst 1991;83:1734-1739. 
36 Nomura A, Stemmermann G, Chyou $P$ et all. Helicobacter pylori infection and gastric carcinoma among Japanese Americans in Hawaii. $N$ Engl $J$ Med $1991 ; 325: 1132-1136$.

37 Kikuchi $S$, Wada $O$, Nkajima $T$ et al. Serum anti-Helicobacter pylori antibody and gastric carcinoma among young adults. Cancer 1995;75:2789-2793.

38 Kuipers E, Gracia-Casanova $M$, Pena $S$ et al. Helicobacter pylori serology in patients with gastric carcinoma. Scand J Gastroenterol 1993;28:433-437.

39 Webb P, Yu M, Forman D et al. An apparent lack of association between Helicobacter pylori infection and risk of gastric cancer in China. Int $J$ Cancer 1996;67:603-607.

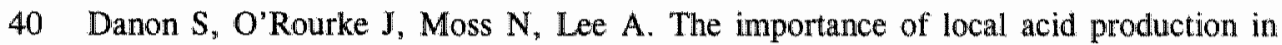
the distribution of Helicobacter felis in the mouse stomach. Gastroenterol $1995 ; 108: 1386-1395$.

41 Logan R, Walkers $M$, Misiewicz $M$ et al. Changes in the intragastric distribution of Helicobacter pylori during treatment with oneprazole. Gut 1995;36:12-16.

42 Kuipers E, Uyterlinde A, Pena $S$ et al. Increase of Helicobacter pylori-associated corpus gastritis during acid suppressive therapy: implications for long-term safety. Am J Gastroenterol 1995; 90: 1401-1406.

43 Louw J, Falck V, van Rensburg C et al. Distribution of Helicobacter pylori colonisation and associated gastric inflammatory changes: difference between patients with duodenal and gastric ulcers. I Clin Pathol 1993;46:754-756.

44 Hansson L, Engstrand L, Nyrén $O$ et al. Helicobacter pylori infection: independent risk indicator of gastric adenocarcinoma. Gastroenterol 1993;105:1098-1103.

45 Blaser M, Chyou P, and Nomura A. Age at establishment of Helicabacter pylori infection and gastric carcinoma, gastric ulcer, and duodenal ucler risk. Cancer Research (1995) 55:562-565.

46 Hansson L, Nyrén O, Hsing A et al. The risk of stomach cancer in patients with gastric or duodenal ulcer disease. N Engl J Med 1996;335:242-249. 


\section{Chapter VIII}

\section{General discussion}




\section{General Discussion}

Worldwide, in terms of cancer mortality, gastric cancer is second in importance to lung cancer. However, in the last decennia a consistent decline in gastric cancer mortality was seen in nearly all countries, and this is primarily due to a decrease of the intestinal type of gastric cancer, while on the other hand the incidence of the diffuse type of gastric carcinoma gradually increases.

It is evident that in the search for the causes of gastric cancer causative agents are likely to be widespread, variable in prevalence between populations, and declining in importance, or that protective agents are widespread, variable and increasing in prevalence, or a combination of both. This thesis deals with some risk factors in the aetio-pathogenesis of gastric cancer.

In chapter I an overview of the recent literature on risk factors in the aetiopathogenesis of gastric cancer is given, with special attention to atrophic gastritis, Helicobacter pylori (H.pylori), and hypergastrinaemia with hyperplasia of enterochromaffinlike (ECL) cells.

In chapter II the frequency of Helicobacter pylori associated peptic ulcer disease and of autoimmune-associated conditions in gastric cancer patients was compared with renal cancer patients. We tried to elucidate to which proportion H.pyloriassociated conditions and autoimmune phenomena, both suggested to be related to gastric cancer, occurred in a consecutive series of patients with gastric cancer, compared with a control population of patients with renal cancer. The condition which is closest associated with H.pylori (duodenal ulcer) was not correlated with gastric cancer, which seems to exclude a direct carcinogenic effect of the bacterium. An alternative explanation could be a varying virulence of different H.pylori types determining the progression of gastritis. Autoimmune phenomena have long been associated with gastric cancer, and our study gives evidence that this correlation is still as strong as previously described. This study has shown that autoimmune-associated conditions are as frequent as H.pylori-associated conditions in gastric cancer.

In the treatment of acid related diseases an optimal inhibition of gastric acid secretion has to be found. This means on the one hand providing a high or even $100 \%$ healing rate of target lesions, but on the other hand avoiding side-effects of such treatment as much as possible: in some way this means sailing between Scylla and Charybdis.

In chapter III 24-hour intragastric acidity was measured in healthy volunteers in a direct comparison between placebo, $300 \mathrm{mg}$ ranitidine b.d., $20 \mathrm{mg}$ omeprazole o.m., and $40 \mathrm{mg}$ omeprazole o.m, the latter drug doses that are used as standard therapy in acid-related disorders. The decrease in gastric acid secretion after 
ranitidine, given twice daily, was most marked at night. Omeprazole decreased gastric acidity during both daytime and night-time; however, in absolute terms inhibition was stronger during the day. The median $\mathrm{pH}$ during night-time did not reach pH 5, neither with $20 \mathrm{mg}$ omeprazole nor with $40 \mathrm{mg}$ omeprazole given once daily. Therapeutically the consequence seems to be that, in patients with severe peptic ulcer disease or reflux oesophagitis, omeprazole should preferably be given twice daily instead of doubling the morning dose.

Possible side-effects of acid inhibition, such as bacterial overgrowth and hypergastrinaemia are studied in the next chapters IV, V, and VI.

In chapter IV intragastric bacterial growth, nitrates, nitrites, and $\mathrm{N}$-nitroso compounds (NOC) after the above mentioned three different regimens of acid inhibition, were studied compared to placebo. All three acid inhibiting treatments resulted in a significant and similar increase of the bacterial flora in the gastric juice, mainly of Gram-positive bacteria. It can be hypothesized that the moderate elevation of the median 24-hour $\mathrm{pH}$ exerted by ranitidine $300 \mathrm{mg}$ b.i.d. has already surpassed the threshold which is necessary for intragastric bacterial colonization to take place. It also became evident that intragastric bacterial overgrowth was mainly correlated to the hypochlorhydria present during the daytime period. This may indicate that bacteria cultured from fasting gastric juice are not just a consequence of nightly acid inhibition, disappearing after any incidental drop of intragastric $\mathrm{pH}$ in the subsequent day-time period, but represent a resident flora with some adherence to the gastric mucosa. Despite the significant increase in bacterial growth after the three acid inhibiting treatments no significant differences in nitrate, nitrite and NOC concentrations were found between the different short-term treatments and placebo. In all forms of treatment the event most closely correlated to the rise of intragastric NOC concentration was the nitrite concentration of the gastric juice, rather than the concentration of intragastric bacteria itself. Nitrite formation - either bacterial or chemical - seems to be the determining factor for the NOC formation. Therefore, if in future studies the consequences of NOC formation during longlasting hypochlorhydria should be assessed, monitoring of intragastric nitrites seems to be an acceptable proxy for the uncertain, cumbersome, and expensive measurement of NOC concentrations.

It has been the subject of much discussion whether intragastric nitrosation of amines can only take place in an acidic milieu or whether it also can occur at the elevated $\mathrm{pH}$ levels that are favourable for bacterial proliferation and nitrite formation. In this study the inverse correlation of 24-hour $\mathrm{pH}$-values with the fasting intragastric NOC concentrations indicates that $\mathrm{N}$-nitrosation of amines can occur at all levels of intragastric acidity but has a preference for the acidic $\mathrm{pH}$ area in which this process is mainly biochemically and not bacterially induced. 
Thus, already short-term moderate as well as profound medical inhibition of gastric acid secretion results in overgrowth of mainly Gram positive bacteria, in a few cases leading to a significant reduction of intragastric nitrate to nitrite. Nitrite formation is then the limiting factor for the formation of N-nitroso compounds, a reaction which tends to take place more easily at lower than at higher intragastric $\mathrm{pH}-$ levels. In order to assess the risk between long-lasting gastric acid inhibition and gastric cancer, monitoring of intragastric nitrite concentrations seems to be an adequate and relatively convenient alternative to estimations of intragastric NOC concentrations.

In chapter $\mathrm{V}$ another possible side effect of acid inhibition, hypergastrinaemia, was studied under basal and meal-stimulated conditions, together with changes in serum pepsinogen $\mathrm{A}$ and $\mathrm{C}$ levels.

In order of $300 \mathrm{mg}$ ranitidine b.d., $20 \mathrm{mg}$ omeprazole o.m., $40 \mathrm{mg}$ omeprazole o.m., each of the treatments produced a significant increase of basal and mealstimulated serum gastrin compared to the previous one and compared to placebo. Serum pepsinogen $\mathrm{A}$ and $\mathrm{C}$ levels were not increased after ranitidine compared to placebo, but higher after $20 \mathrm{mg}$ omeprazole and $40 \mathrm{mg}$ omeprazole compared with both placebo and ranitidine, and higher after $40 \mathrm{mg}$ omeprazole than after $20 \mathrm{mg}$ omeprazole. Positive correlations were found between serum gastrin and serum pepsinogen $\mathrm{A}$ and $\mathrm{C}$ levels, respectively. This study has shown for the first time that the increase of basal and meal-stimulated serum gastrin almost linearly follows the degree of pharmacological acid inhibition. In this context it has to be realized that basal gastrin levels only appeared to be mildly or moderately elevated, whereas the integrated meal-induced gastrin levels on the highest dose of omeprazole reached levels almost four times as high as on placebo.

In addition to its acid stimulating effect, gastrin has a growth-promoting effect. With this in mind, the gradual increase of pepsinogen $\mathrm{A}$ as well as of pepsinogen $\mathrm{C}$ possibly reflects hyperplasia and/or hyperactivity of the gastric chief cell population. Gastric acid inhibition lowers mucosal somatostatin not only in the gastric antrum but also in the gastric fundus. Since somatostatin exerts inlibitory effects on the chief cells, it is possible that this is an other explanation for the hyperpepsinogenaemia observed in this study. It seems unlikely that these changes in serum gastrin and serum pepsinogen $\mathrm{A}$ and $\mathrm{C}$ levels are of importance in shortand medium-term profound acid inhibition. Whether surveillance of long-term acid inhibitory treatment is necessary can at present not be answered definitively. Recent reports about increased cancer rates in patients with elevated gastrin levels decades before the discovery of a malignant event give rise to concern.

In chapter VI the relation between intragastric $\mathrm{pH}$, basal and meal-stimulated serum gastrin, and plasma chromogranin $\mathrm{A}(\mathrm{CgA})$ levels after short term gastric 
inhibition with three different drug doses were studied, in order to see whether these forms of treatment would induce ECL cell hyperactivity. As the measurement of circulating $\mathrm{CgA}$ has been used as a reliable marker for neuroendocrine tumour growth, it may also prove to be a useful marker for the ECL cell population of the stomach. Basal CgA levels and delta CgA levels (the difference in basal CgA before and after treatment) are significantly higher on $20 \mathrm{mg}$ omeprazole and $40 \mathrm{mg}$ omeprazole, compared to placebo and $300 \mathrm{mg}$ ranitidine b.d., respectively. A positive correlation was found between the integrated serum gastrin levels and the $\mathrm{CgA}$ and delta $\mathrm{CgA}$ levels, respectively, as well as between basal serum gastrin levels and $\mathrm{CgA}$ and delta $\mathrm{CgA}$ levels, respectively. This study, involving healthy volunteers and short-term acid inhibition, is the first study to show a correlation between serum gastrin levels and plasma $\mathrm{CgA}$ levels, indicating that plasma $\mathrm{CgA}$ levels could be used as a non invasive marker for ECL-cell function.

Whether the elevated CgA levels will be sustained for a longer period is not yet clear. In humans, carcinoid tumours derived from ECL-cell hyperplasia have been reported in patients with type A autoimmune chronic atrophic gastritis or with the Zollinger-Ellison syndrome as part of the type I multiple endocrine neoplasia (MEN I), both conditions with a long lasting hypergastrinaemia. ECL-cell derived tumour cells are found in $40 \%$ of diffuse gastric carcinomas, by one group of investigators, suggesting that a proportion of the diffuse gastric carcinomas may originate from ECL-cells. Given the slow-growing rate of such malignancies, even modest gastrin elevations over many years may contribute to the pathogenesis of such tumours. It seems unlikely that the changes in gastrin and $\mathrm{CgA}$ levels found in this study, are of importance in short- and medium-term profound acid inhibition. Whether surveillance of long-term treatment is necessary can presently not definitively be answered.

Apart from the above mentioned intragastric overgrowth of non-Helicobacter pylori flora, increasing evidence is found for a role of Helicobacter pylori in gastric carcinogenesis.

In chapter VII H.pylori and non-H.pylori intragastric bacterial flora was studied in patients with intestinal and diffuse type of gastric adenocarcinoma. In the intestinal type of gastric cancer, the histological sequence of H.pylori associated chronic gastritis towards atrophic gastritis and intestinal metaplasia will play a role. The diffuse type may arise more directly from hyperplastic or atypical necks of gastric glands through primary involvement of genes affecting cell - to - cell and cell - to matrix junctional proteins. The onset of either of the two pathways leading to an intestinal or diffuse type of gastric cancer may be influenced by distribution and density of H.pylori, or strain differences, in combination with host and/or environmental factors. One such host factor may be the presence of other bacteria, 
the non- $H$.pylori flora, known to colonize the hypochlorhydric or achlorhydric stomach. The intragastric non-H.pylori flora is able to reduce nitrates to nitrites, and to induce the formation of potentially carcinogenic $\mathrm{N}$-nitroso compounds. Bacterial overgrowth is found in gastric cancer precursor lesions such as atrophic gastritis with or without pernicious anaemia. Thus, in the sequence towards gastric cancer, both H.pylori and non-H.pylori bacterial flora may play a role.

H.pylori was detected in $46.3 \%$ of 82 consecutive gastric cancer patients, nonH.pylori bacterial flora was found in $70.7 \%$ of the patients, with a similar prevalence and distribution in both intestinal and diffuse type carcinomas and irrespective of the tumour localisation. H.pylori only was found in $13.4 \%$, nonH.pylori only in $36.6 \%$, both types of flora in $34.1 \%$, and in $15.9 \%$ no bacterial flora at all was detected using histological methods. The prevalence of H.pylori was higher in corpus than antrum mucosa of both patients with intestinal and with diffuse type gastric cancer. This finding is in line with the high intragastric $\mathrm{pH}$ found in most of the gastric cancer patients, as migration of H.pylori from antrum towards corpus mucosa is known to occur in hypochlorhydric or achlorhydric patients.

H.pylori positive gastric cancer patients were significantly younger than patients without H.pylori. Acquisition of H.pylori at young age is associated with an increased risk for gastric ulcer but not for duodenal ulcer. Gastric ulcer patients are at higher risk to develop gastric cancer in comparison with duodenal ulcer patients, so acquisition of H.pylori at young age may be associated with an increased gastric cancer risk.

The relative low prevalence of H.pylori and the abundant presence of the nonH.pylori flora at the time of cancer diagnosis will not necessarily reflect the situation during the initial stages of gastric carcinogenesis. From this study it is not possible to exclude that the growth of non-H.pylori is a consequence of the histological changes, connected with reduced gastric acidity, such as in atrophic gastritis. These may be caused by chronic H.pylori gastritis or autoimmune processes, or other factors. After colonisation of the stomach, the non-H.pylori flora may then contribute to the progression of gastric cancer by acting as an antigenic trigger or by the production of toxic or carcinogenic metabolites, such as $\mathrm{N}$-nitroso compounds.

The time course from the initial events in the cascade until gastric cancer development will probably take several decades. In this study the increase in age between the patient group with H.pylori only, to that with both H.pylori and non$H$.pylori, and finally to the group with non-H.pylori only, suggests that H.pylori may play an initial role leading to histological changes such as chronic gastritis with atrophy and intestinal metaplasia. When intragastric $\mathrm{pH}$ increases non-H.pylori 
may start to colonize the gastric mucosa. Even later when the environment become too hostile, H.pylori colonization will decrease. The finding of patients with positive serology and negative histology for H.pylori, supports an initial role of H.pylori in gastric cancer.

Gastric carcinogenesis seems to be a multifactorial process.

The patient age, at which the infection with H.pylori starts, the massivity of the infection and possibly the bacterial strain(s) may be such factors. Other factors in relation with gastric carcinogenesis seems to be autoimmune associated precancerous conditions, leading to hypo- and achlorhydria, both conditions that are potentially carcinogenic. ECL cell hyperplasia as the result of the trophic effect of hypergastrinaemia is another factor in the discussion concerning gastric carcinogenesis, rellevant both during long-term acid inhibition and in autoimmune diseases. In the intestinal type and the diffuse type of gastric cancer both $H$.pylori and non-H.pylori flora are present in a high percentage and may both be involved in gastric carcinogenesis.

This study has investigated several factors potentially involved in the pathogenesis of gastric cancer: autoimmune diseases, infection with H.pylori, bacterial overgrowth with non-H.pylori flora and its metabolic consequences, hypergastrinaemia and subsequent ECL-cell hyperactivity/hyperplasia.

The picture evolving is that of a multifactorial process with components, either independently or dependently from each other, conditioning the following step(s). The phenotype of the cancer at the moment of diagnosis appears very heterogenous, and the single important carcinogenic factors are difficult to discern. Ongoing and future research has to concentrate on some main strects of gastric carcinogenesis. Hereby H.pylori will certainly be of prominent importance but other factors must not be overlooked. 


\section{Chapter IX}

\section{Summary}




\section{Summary}

This thesis deals with some risk factors in the aetio-pathogenesis of gastric cancer.

In chapter I an overview of the recent literature on risk factors in the aetiopathogenesis of gastric cancer is given, with speciall attention to atrophic gastritis, Helicobacter pylori (H.pylori), non-H.pylori intragastric bacterial flora, and hypergastrinaemia with hyperplasia of enterochromaffinlike (ECL) cells.

In chapter II the frequency of H.pylori associated peptic ulcer disease and of autoimmune-associated conditions in gastric cancer patients was retrospectively compared with renal cancer patients. The condition which is closest associated with H.pylori infection of the stomach (duodenal ulcer) was not correlated with gastric cancer. This study has shown that autoimmune-associated conditions are as frequent as $H$.pylori-associated conditions in gastric cancer.

In chapter III 24-hour intragastric acidity was measured in healthy volunteers in a direct comparison between placebo, $300 \mathrm{mg}$ ranitidine b.d., $20 \mathrm{mg}$ omeprazole o.m., and $40 \mathrm{mg}$ omeprazole o.m., the three drug doses representing standard therapies in acid-related disorders. The decrease in gastric acid secretion after ranitidine, given twice daily, was most marked at night. Omeprazole decreased gastric acidity during both daytime and night-time; however, in absolute terms inhibition was stronger during the day. The median $\mathrm{pH}$ during night-time did not reach $\mathrm{pH} 5$, neither with $20 \mathrm{mg}$ omeprazole nor with $40 \mathrm{mg}$ omeprazole given once daily.

Possible side-effects of acid inhibition, such as bacterial overgrowth and hypergastrinaemia, are studied in the next chapters IV, V, and VI.

In chapter IV intragastric bacterial growth, nitrates, nitrites, and $\mathrm{N}$-nitroso compounds (NOC) after the above mentioned three different regimens of acid inhibition were studied, compared to placebo. All three short-lerm acid inhibiting treatments resulted in a significant and similar increase of the bacterial flora in the gastric juice, mainly of Gram-positive bacteria. It became evident that intragastric bacterial overgrowth was mainly correlated to the hypochlorhydria present during the daytime period. Despite the significant increase in bacterial growth after the three acid inhibiting treatments no significant differences in nitrate, nitrite and NOC concentrations were found between the different short-term treatments and placebo. In all forms of treatment the event most closely correlated to the rise of intragastric NOC concentration was the nitrite concentration of the gastric juice, rather than the concentration of intragastric bacteria itself. Nitrite formation - either bacterial or chemical - seems to be the determining factor for the NOC formation. In this study the inverse correlation of 24-hour pH-values with the fasting intragastric NOC concentrations indicates that $\mathrm{N}$-nitrosation of amines can occur at 
all levels of intragastric acidity but has a preference for the acidic $\mathrm{pH}$ area in which this process is mainly biochemically and not bacterially induced.

In chapter $\mathbf{V}$ another possible side effect of acid inhibition, hypergastrinaemia, was studied under basal and meal-stimulated conditions, together with changes in serum pepsinogen $A$ and $C$ levels. In order of ranitidine $300 \mathrm{mg}$ b.d., $20 \mathrm{mg}$ omeprazole o.m., $40 \mathrm{mg}$ omeprazole o.m., each of the treatments produced a significant increase of basal and meal-stimulated serum gastrin compared to the previous one and compared to placebo. Serum pepsinogen $\mathrm{A}$ and $\mathrm{C}$ levels were not increased after ranitidine compared to placebo, but higher after $20 \mathrm{mg}$ omeprazole and $40 \mathrm{mg}$ omeprazole compared with both placebo and ranitidine, and higher after $40 \mathrm{mg}$ omeprazole than after $20 \mathrm{mg}$ omeprazole. Positive correlations were found between serum gastrin and serum pepsinogen $\mathrm{A}$ and $\mathrm{C}$ levels, respectively. This study has for the first time shown that the increase of basal and meal-stimulated serum gastrin almost linearly follows the degree of pharmacological acid inhibition. Basal gastrin levels appeared only to be mildly or moderately elevated, whereas the integrated meal-induced gastrin levels on the highest dose of omeprazole reached levels almost four times as high as on placebo.

In chapter VI the relation between intragastric $\mathrm{pH}$, basal and meal-stimulated serum gastrin, and plasma chromogranin $\mathrm{A}(\mathrm{CgA})$ levels, a marker of neuroendocrine tumour growth, after short term gastric inhibition with the three different drug doses were studied, in order to see whether these forms of treatment would induce ECL cell hyperactivity. Basal $\mathrm{CgA}$ levels and delta $\mathrm{CgA}$ levels (the difference in basal $\operatorname{CgA}$ before and after treatment) are significantly higher on $20 \mathrm{mg}$ omeprazole and $40 \mathrm{mg}$ omeprazole than after placebo and $300 \mathrm{mg}$ ranitidine b.d., respectively. Positive correlations were found between the integrated serum gastrin levels and the $\mathrm{CgA}$ and delta $\mathrm{CgA}$ levels, respectively, as well as between basal serum gastrin levels and $\mathrm{CgA}$ and delta $\mathrm{CgA}$ levels respectively. This study, involving healthy wolunteers and short-term acid inhibition, is the first study to show a correlation between serum gastrin levels and plasma CgA levels, indicating that plasma $\mathrm{CgA}$ levels could be used as a non invasive marker for ECL-cell hyperfunction/hyperplasia.

In chapter VII H.pylori and non-H.pylori intragastric bacterial flora was studied in patients with intestinal and diffuse type of gastric adenocarcinoma. H.pylori was detected in $46.3 \%$ of 82 consecutive gastric cancer patients, non-H.pylori bacterial flora was found in $70.7 \%$ of the patients, with a similar prevalence and distribution in both intestinal and diffuse type carcinomas and irrespective of the tumour localisation. H.pylori only was found in $13.4 \%$, non-H.pylori only in $36.6 \%$, both types of flora in $34.1 \%$, and in $15.9 \%$ no bacterial flora at all was detected using histological methods. The prevalence of H.pylori was higher in corpus than antrum 
mucosa both of patients with intestinal and with diffuse type gastric cancer. H.pylori positive gastric cancer patients were significantly younger than patients without H.pylori.

Chapter VIII embodies the general discussion on the aetiopathogenesis of gastric cancer, integrating data from clinical and experimental studies presented in previous chapters. The final conclusion is, that besides H.pylori, overgrowth of non- H.pylori intragastric flora, intragastric nitrosamines, hypergastrinaemia, ECLcell hyperplasia, and auto-immune phenomena must be considered in gastric carcinogenesis. 


\section{Chapter X}

\section{Samenvatting}




\section{Samenvatting}

Dit proefschrift behandelt een aantal risico factoren, die van belang zijn in de pathogenese van maagkanker.

In hoofdstuk I wordt een overzicht gegeven van de recente literatuur over risico factoren in de pathogenese van maagkanker, met speciale aandacht voor atrofische gastritis, Helicobacter pylori (H.pylori), andere niet-H.pylori bacteriën in de maag, en verhoogde gastrine spiegels (hypergastrinemie) met hyperplasie van de enterochromaffine-achtige ( $\mathrm{ECL}$ ) cellen.

In hoofdstuk II wordt de frequentie van met H.pylori geassocieerd peptisch ulcus lijden en van autoimmuun geassocieerde condities bij patiënten met maagkanker retrospectief vergelijken met patiënten met nierkanker. Voor die conditie die het sterkst geassocieerd is met een H.pylori infectie van de maag (ulcus duodeni), bestond er geen correlatie met maagkanker. Deze studie heeft aangetoond dat bij patiënten met maagkanker autoimmuun geassocieerde condities even vaak voorkomen als H.pylori geassocieerde condities.

In hoofdstuk III is de 24-uurs zuursecretie van de maag gemeten bij gezonde vrijwilligers in een direct vergelijk tussen placebo, $300 \mathrm{mg}$ ranitidine twee maal daags, $20 \mathrm{mg}$ omeprazole 's morgens en $40 \mathrm{mg}$ omeprazole 's morgens, standaard therapieën bij zuurgerelateerde aandoeningen. Ranitidine, twee maal daags gegeven remt de maagzuursecretie het sterkst gedurende de nacht. Omeprazole remt de maagzuursecretie zowe』 overdag als 's nachts; echter de remming is het meest uitgesproken overdag. De mediane $\mathrm{pH}$ gedurende de nacht stijgt niet boven 5 , noch met één maal daags $20 \mathrm{mg}$ omeprazole, noch met één maal daags $40 \mathrm{mg}$ omeprazolle.

Mogelijke bijwerkingen van zuurremming, zoals bacteriële overgroei en hypergastrinemie werden bestudeerd in de hoofdstukken IV, V, en VI.

In hoofdstuk IV worden bacteriële overgroei, nitraat, nitriet, en $\mathrm{N}$-rititroso verbindingen (NOC) in de maag bestudeerd, na bovengenoemde zuurremmende therapieën, en vergeleken met placebo. Kortdurende behandeling met alle drie de zuurremmende therapieën resulteerde in een significante en gelijke toename van de bacteriële flora in het maagsap, van met name Gram-positieve bacteriën. Het werd duidelijk dat bacteriële overgroei in de maag, met name gecorreleerd was met hypochloorhydrie overdag. Ondaniks de significante toename van de bacterièle flora in de maag na de drie verschillende zuurremmende therapieën, werd er geen significant verschil gevonden in nitraat, nitriet en $\mathrm{N}$-nitroso verbindingen tussen de verschillende kortdurende behandelingen en placebo. Bij alle vormen van zuurremmende therapie, was die factor die het sterkst gecorreleerd was met de toename van de NOC concentratie in het maagsap, de nitriet concentratie van het 
maagsap, en niet de concentratie van de bacteriën zelf. De vorming van nitriet bacterieel dan wel chemisch - lijkt de determinerende factor te zijn voor de NOC vorming. De in deze studie gevonden negatieve correlatie tussen 24-uurs $\mathrm{pH}$ waarden en NOC concentraties in de maag, geeft aan dat $\mathrm{N}$-nitrosering van amines kan plaats vinden gedurende elke $\mathrm{pH}$ waarde in de maag, maar met een voorkeur voor het zure $\mathrm{pH}$ gebied, waarin dit proces hoofdzakelijk biochemisch en niet bacterieel wordt geinduceerd.

In hoofdstuk $\mathbf{V}$ wordt een andere mogelijke bijwerking van zuurremming, hypergastrinemie, bestudeerd, zowel basaal als maaltijd gestimuleerd, tezamen met veranderingen van het serum pepsinogeen $\mathrm{A}$ en C. $300 \mathrm{mg}$ ranitidine twee maal daags, $20 \mathrm{mg}$ omeprazole 's morgens, $40 \mathrm{mg}$ omeprazole 's morgens, in deze volgorde geven aanleiding tot een significante stijging van basale en maaltijd gestimuleerde serum gastrine spiegels in vergelijking met de voorafgaande behandeling en placebo. Serum pepsinogeen $\mathrm{A}$ en $\mathrm{C}$ concentraties waren miet gestegen na ranitidine in vergelijking met placebo, maar waren wel hoger na $20 \mathrm{mg}$ omeprazole en $40 \mathrm{mg}$ omeprazole in vergelijking met placebo en ranitidine, en waren hoger na $40 \mathrm{mg}$ omeprazole in vergelijking met $20 \mathrm{mg}$ omeprazole. Positieve correlaties werden gevonden tussen serum gastrine en serum pepsinogeen A en $\mathrm{C}$ waarden, respectievelijk. Deze studie heeft voor de eerste keer aangetoond, dat de toename van de basale en maaltijd gestimuleerde serum gastrine waarden, vrijwel lineair verloopt met de graad van farmacologische zuurremming. Basale serum gastrine waarden zijn slechts licht tot matig verhoogd, terwijl de geintegreerde maaltijd gestimuleerde serum gastrine waarden na de hoogste dosis omeprazole waarden bereiken die vrijwel vier maal zo hoog zijn als na placebo.

In hoofdstuk VI wordt de relatie bestudeerd tussen de zuurgraad in de maag, basale en maaltijd gestimuleerde serum gastrine waarden, en plasma chromogranine A $(\mathrm{CgA})$ warden, een merker voor neuroendocriene tumor groei, na kortdurende zuurremming met de drie verschillende therapieën, om na te gaan of deze verschillende behandelingen in staat zijn ECL cel hyperactiviteit te induceren. Basale $\mathrm{CgA}$ waarden, en delta $\mathrm{CgA}$ waarden (het verschil in basale $\mathrm{CgA}$ waarden voor en na behandeling) zijn significant hoger na $20 \mathrm{mg}$ omeprazole en $40 \mathrm{mg}$ omeprazole dan na placebo en twee maal daags $300 \mathrm{mg}$ ranitidine, respectievelijk. Positieve correlaties werden gevonden tussen de geintegreerde serum gastrine waarden en de $\mathrm{CgA}$ en delta $\mathrm{CgA}$ waarden, respectievelijk, evenals tussen de basale serum gastrine waarden en de $\mathrm{CgA}$ en delta $\mathrm{CgA}$ waarden respectievelijk. Deze studie verricht bij gezonde vrijwilligers met kortdurende zuurremming, is de eerste studie, die een correlatie laat zien tussen serum ǵastrine waarden en plasma $\mathrm{CgA}$ warden, inducerend dat plasma $\mathrm{CgA}$ waarden gebruikt kunnen worden als een niet-invasieve merker voor ECL cel hyperfunctie/hyperplasie. 
In hoofdstuk VII werd de bacteriële maagflora, H.pylori en niet-H.pylori, bestudeerd bij patiënten met het intestinale en het diffuse type maagkanker. H.pylori werd gevonden bij $46,3 \%$ van de 82 patiënten met maagkanker die werden bestudeerd, niet-H.pylori bacteriële flora werd gevonden bij $70,7 \%$ van de patiënten, met een gelijke prevalentie en verdeling in beide types van maagkanker, intestinale en diffuse type. Alleen H.pylori werd gevonden in $13,4 \%$ van de gevallen, alleen niet-H.pylori in $36,6 \%$ van de gevallen, beide types bacteriên in $34,1 \%$ van de gevallen, en in $15,9 \%$ van de gevallen kon geen enkele bacteriële flora middels histologische methodes worden aangetoond. De prevalentie van H.pylori was hoger in de corpus dan in de antrum mucosa van zowel patiënten met het intestinale type maagkanker, als van patiënten met het diffuse type maagkanker. Maagkanker patiënten met H.pylori waren significant jonger, dan maagkanker patiënten zonder H.pylori.

Hoofdstuk VIII bevat de slotdiscussie en conclusies omtrent de pathogenese van maagkanker, waarbij de gegevens van de klinische en experimentele studies gepresenteerd in de voorgaande hoofdstukken worden geintegreerd. De uiteindelijke conclusie is, dat naast H.pylori, andere factoren zoals niet-H.pylori bacteriële maagflora, nitrosamines in het maagsap, hypergastrinemie, ECL cel hyperplasie en autoimmuun fenomenen moeten worden betrokken in de carcinogenese van de maag. 


\section{Dankwoord}




\section{Dankwoord}

Graag wil ik iedereen bedanken die heeft bijgedragen aan de totstandkoming van dit proefschrift. Een aantal van hen moeten specifiek genoemd worden, zonder anderen te kort te willen doen.

Een speciaal woord van dank will ik richten aan mijn promotor, Prof Stockbrügger, beste Reinhold. Zonder jouw was dit proefschrift er niet gekomen. Voortbordurend op jouw eigen werk heb jij mij steeds in raad en daad bijgestaan. Jouw begeleiding is voor mij van onschatbare waarde geweest, met name ook in de periode nadat ik Maastricht verruild had, voor een drukke perifere plek alls internist-gastroenteroloog in Zeeuws-Vlaanderen. Ik kwam naar Maastricht voor een gastroenterologie-opleiding en on te promoveren, twee zaken die in de praktijk vaak moeilijk te verenigen zijn. Tk ben je zeer erkentelijk dat je beide toch mogelijk hebt gemaakt.

Daarnaast wil ik mijn beide co-promotores bedanken. Wim Hameeteman, jij hield steeds de grote lijnen in de gaten, en voorzag mij van opbouwend en kritisch commentaar. Adriaan de Bruine, voor al die uren die wij samen achter de microscoop hebben doorgebracht, op zoek naar maagkanker, voorstadia en bacteriën.

De leden van de beoordelingscommissie, Prof dr PB Soeters, Prof dr PJC wan Breda Vriesman, Prof dr JCS Kleinjans, Prof dr CBHW Lamers en Prof dr JW Rode, will ik bedanken voor de kritische beoordeling van mijn proefschrift.

Door het klinische karakter van de verschillende studies was de medewerking van proefpersonen en patiënten onontbeerlijk.

Met veel geduld ondergingen zij de verschillende metingen. Ik wil hen graag danken woor hun bereidwilligheid om aan de studies deel te nemen.

De studies zijn uitgevoerd op de functie-afdeling en endoscopie-afdeling van het Academisch Ziekenhuis Maastricht. De endoscopisten Reinhold Stockbrügger, Wim Hameeteman, Robert-Jan Brummer, Bart van Hoek, Raoul Zeijen, en Maurice Russel dank ik hartelijk voor het nemen van die extra biopten bij weer een patiënt met een maagcarcinoom. De hoofden van de endoscopie-afdeling, de balie-medewerksters en de endoscopie-assistentes dank ik alle voor hun inspanningen en de zeer prettige samenwerking.

Anita Ruygers en Jurenne Hooi dank ik voor de hulp bij het afnemen en verwerken van all die maagsap monsters en bloed monsters.

Dr I Biemond wil ik bedanken voor de bereidwilligheid om de serum gastrines en pepsinogenen te bepalen, en tevens voor het waardevolle commentaar betreffende hoofdstuk V en VI.

Prof Lundqvist, dear Gudmar. I would like to thank you for the measurement of the plasma chromogranin A levels, and your critical review of the manuscript described in chapter VI.

Beste Daisy Jonkers, mede dank zij jouw onuitputtelijke hulp hebben wij vandaag samen iets te vieren.

Mijn maatschapsgenoten, Wilfred Frijlink, Terje Hoyset, Jan van der Knaap, Cees wan 
der Peyl, Loek van Reisen, en Jos Spijker, wil ik hartelijk danken woor het vertrouwen dat ze in mij gesteld hebben, en voor hun bereidheid om op de donderniddag regelmatig klinische taken van mij over te nemen.

Christien, mijn secretaresse, bedankt woor al jouw hulp bij het printen en kopiëren. Tiny Wouters, bedankt voor het drukklaar maken van het manuscript.

Tot slot dank ik jou, Peter, voor al je zichtbare en onzichtbare hulp. 


\section{Curriculum Vitae}




\section{Curriculum Vitae}

De auteur van dit proefschrift werd geboren op 22 augustus 1957 te Maastricht. Na het behalen van het eindexamen Atheneum B aan het Henric van Veldeke college te Maastricht in 1975, studeerde hij aan de Katholieke Universiteit Nijmegen achtereenvolgens Tandheelkunde' (van 1975 tot 1979, kandidaatsexamen in 1979) en Geneeskunde vanaf 1979. Het artsexamen werd behaald in juni 1986. Na 9 maanden werkzaam te zijn geweest als assistent-geneeskundige niet-in-opleiding, startte hij in april 1987 met de opleiding Interne Geneeskunde in het de Wever Ziekenhuis te Heerlen (opleider dr FATh Lustermans), welke vanaf april 1991 werd vervolgd in het Academisch Ziekenhuis Maastricht (opleider Prof dr JA Flendrig $\dagger$ ). Na de registratie als internist op 1 april 1993 startte hij met de opleiding Gastroenterologie in het Academisch Ziekenhuis Maastricht (opleider Prof dr RW Stockbrügger), welke hij per 1 jamuari 1996 voltooide. Sedertdien is hij werkzaarm als internist-gastroenteroloog in het Ziekenhuis Zeeuws-Vlaanderen. 